\title{
27. SILICOFLAGELLATE BIOSTRATIGRAPHY OF MIDDLE EOCENE TO HOLOCENE SUBANTARCTIC SEDIMENTS RECOVERED BY DEEP SEA DRILLING PROJECT LEG 71 ${ }^{1}$
}

\author{
Cynthia A. Shaw ${ }^{2}$ and Paul F. Ciesielski, University of Georgia, Athens, Georgia
}

\begin{abstract}
Subantarctic sediments recovered in the Southwest Atlantic during Leg 71 provide well-preserved and often diverse silicoflagellate assemblages of middle Eocene, late Eocene-early Miocene, and late middle Miocene through Holocene age. Two holes, 511 and 513A, comprise a complete 370-meter upper Eocene to lower Miocene composite reference section which is divided into six new or revised silicoflagellate zones, in ascending order: the Mesocena occidentalis Zone, Naviculopsis trispinosa Oppel Zone, $N$. constricta/Dictyocha deflandrei Concurrent Range Zone, $N$. constricta-Corbisema archangelskiana Interval Zone, $C$. archangelskiana Range Zone, and Naviculopsis biapiculata Partial Range Zone. New species described from this upper Eocene to lower Miocene section include D. alta, Mesocena bispicata, and Distephanus crux paulii.

Middle Eocene sediments hydraulically piston cored at Site 512 are assigned to the newly constructed Dictyocha grandis Range Zone and are subdivided into three subzones; the $D$. stelliformis Subzone, $D$. stelliformis-M. apiculata Interval Subzone, and M. apiculata Subzone. Paleomagnetic measurements and correlations of this middle Eocene section indicate deposition of the $D$. grandis Zone between $\sim 43.7$ to $40.9 \mathrm{Ma}$. New species from this interval include $D$. anguinea, $D$. grandis, and $D$. stelliformis.

Miocene to Holocene sediments present in hydraulically piston cored Sites 512 and 514 and the rotary cored Site 513 contain the $M$. circulus Zone, $M$. circulus/M. diodon Zone, $M$. diodon Zone, and Distephanus boliviensis Zone. The upper boundaries of these zones are correlated directly with magnetostratigraphy and lie in upper Chronozone 9, upper Chronozone 6, the lower Gilbert Chronozone, and the lower Gauss Chronozone, respectively.

A detailed analysis was made of all silicoflagellate skeletal morphotypes present in the upper Eocene-lower Oligocene to determine the limits of species variability. Numerous sporadically occurring species were determined to be intraspecific variations of more abundant species and are placed in synonymy with these species.
\end{abstract}

\section{INTRODUCTION}

Leg 71 of the Deep Sea Drilling Project rotary drilled or hydraulically piston cored four sites in subantarctic regions of the Southwest Atlantic Ocean (Fig. 1). Two sites are located on the Falkland Plateau-Site 511 in the basin province of the Plateau and Site 512 on the northeastern part of the Maurice Ewing Bank. Sites 513 and 514 are located on the lower west flank of the MidAtlantic Ridge, east of the Argentine Basin. Sites 511 and 512 lie within the present-day Antarctic Convergence zone (Gordon et al., 1977; Ciesielski, 1978), whereas Sites 513 and 514 are approximately 240 and $400 \mathrm{~km}$, respectively, north of the Antarctic Convergence.

Deep Sea Drilling Project Leg 71 was the fifth cruise of the Glomar Challenger to the southern high latitudes. Three of the previous cruises were to the Pacific sector of the Southern Ocean: Legs 28 and 29 went to the Southwest Pacific and Leg 35 to the Southeast Pacific. The fourth high-latitude cruise, Leg 36, drilled in the Southwest Atlantic Ocean, on or in the vicinity of the Falkland Plateau.

A number of investigators have described the silicoflagellate assemblages recovered by the previous DSDP Legs to the Southern Ocean (Bukry, 1975a, b, 1976a; Ciesielski, 1975; Perch-Nielsen, 1975; Busen and Wise,

\footnotetext{
${ }^{1}$ Ludwig, W. J., Krasheninnikov, v. A., et al., Init. Repts. DSDP, 71: Washington (U.S, Govt. Printing Office).

2 Present address: P.O, Box 2189, Exxon Company USA, Houston, Texas, 77001.
}

1977; and Haq and Riley, 1976). To date, silicoflagellate assemblages have been described from Southern Ocean sediments representing each of the Tertiary epochs; however, most of the studied stratigraphic sections are replete with disconformities and difficult to correlate from one region to another.

In this chapter we describe the silicoflagellate assemblages present in the Tertiary sediments recovered during DSDP Leg 71; these range in age from the middle Eocene to Holocene (Fig. 2). Particular emphasis is placed on a detailed quantitative description of silicoflagellate taxa present in upper Eocene through lower Miocene sediments from Holes 511 and 513A (Fig. 2), which represent a composite reference section of the upper Eocene-lower Miocene that is apparently uninterrupted by major disconformities and more complete than any other section of equivalent age in the southern high latitudes.

Another major goal of this study is to attempt to determine the range of intraspecific variability exhibited by Paleogene silicoflagellates. To do this we made a detailed quantitative study of all silicoflagellate skeletal morphotypes present in the middle Eocene of Hole 512 and the upper Eocene-lower Oligocene of Hole 511. An evaluation of the quantitative assemblage data for these stratigraphic sections (taxonomic section, this chapter) reveals evidence for a high degree of specific skeletal variability. A number of recently described species appear to be intraspecific variations of previously described species and are herein placed in synonoymy with these species. 


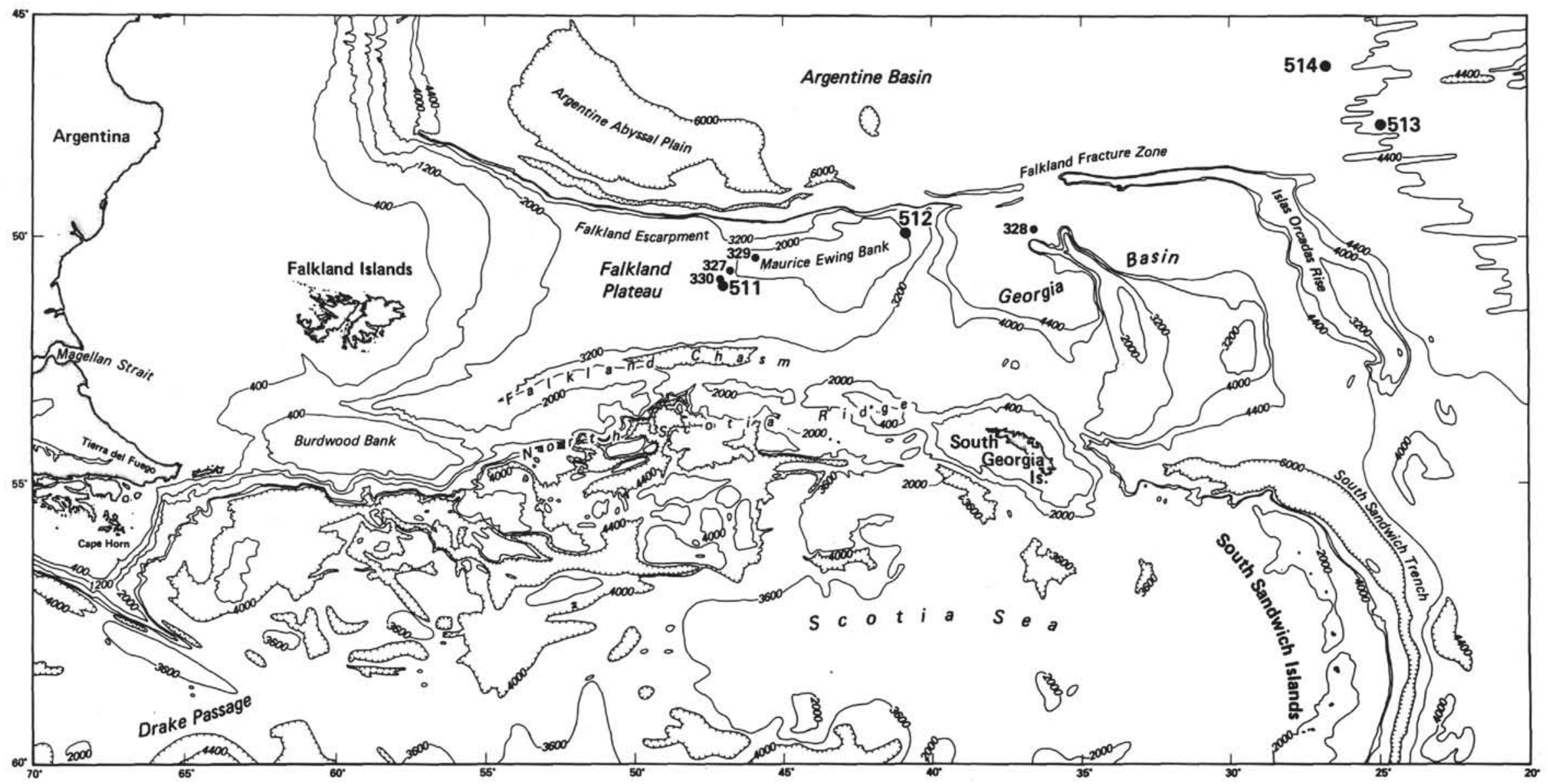

Figure 1. Location of DSDP Leg 71 sites. 

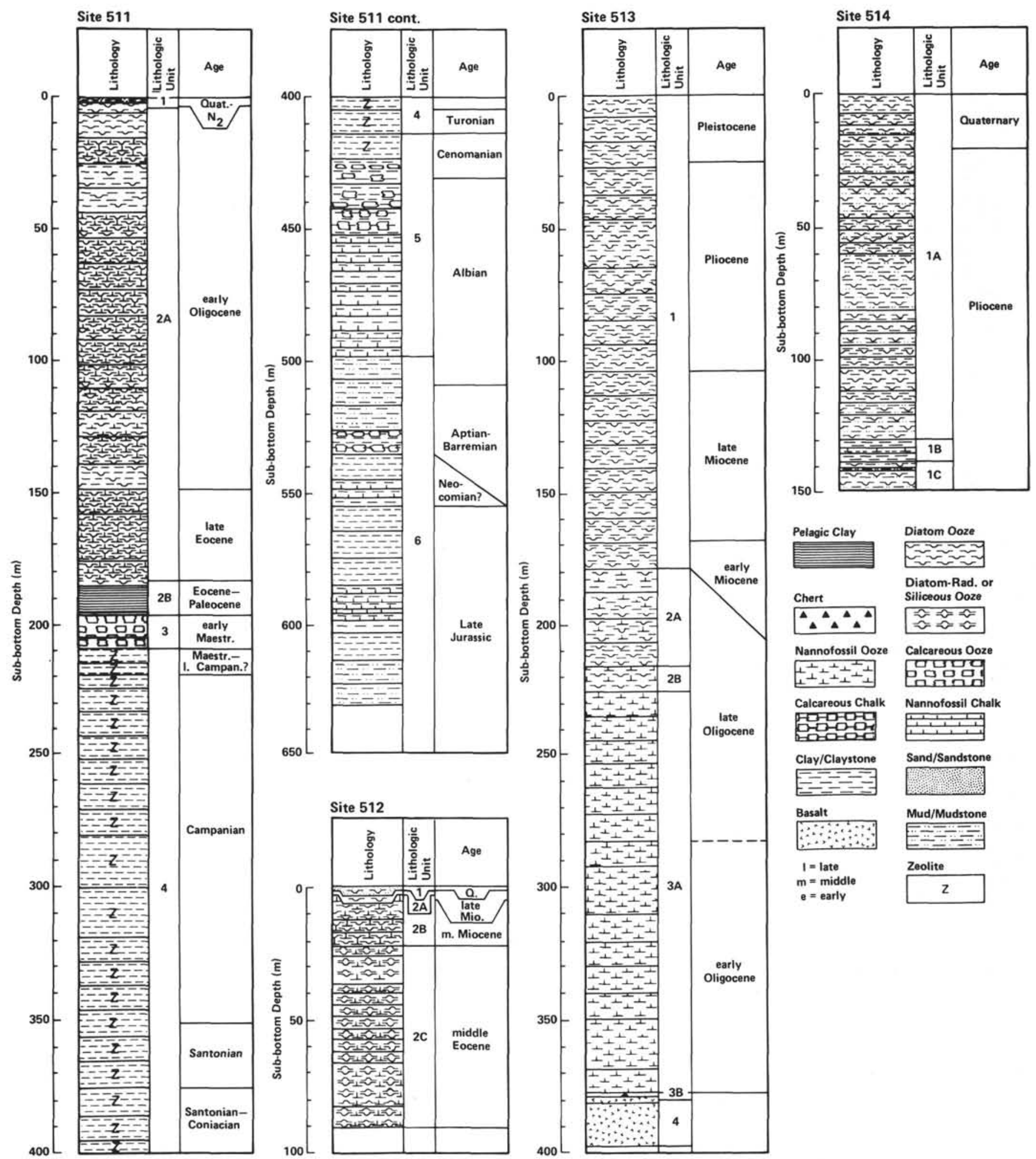

Figure 2. Lithological sections of Sites 511-514.

\section{PREPARATION OF SAMPLES AND METHOD OF STUDY}

All samples used in this study were collected by Ciesielski during Leg 71. A total of 316 samples were processed for shore-based investigations using the following technique: Raw samples were placed in 200 $\mathrm{ml}$ beakers and heated with diluted hydrogen peroxide to disassociate the sediment and remove the organic carbon. Hydrochloric acid was then added to dissolve any carbonate present in the samples. The undissolved residues were diluted with distilled water, centrifuged, and decanted to remove the acid. This procedure was repeated three times. Next, the samples were washed with sodium pyrophosphate, centrifuged, and decanted to remove a significant proportion of the clay 
present in the samples. This step was repeated until the sediment suspension obtained a neutral $\mathrm{pH}$. Processed residues were diluted with distilled water and stored in $50 \mathrm{ml}$ plastic bottles.

Strewn slides of all samples were prepared by shaking bottles containing the sediment and water until all sediment was in solution, and a small amount of the suspension was pipetted from the middle of the bottle. A few drops of the pipetted solution were placed on a slide and dispersed uniformly. After the slides dried, cover slips were mounted using Hyrax (n.d. $=1.71$ ) as the mounting medium.

Selected samples were sieved after preparation of the whole-fraction slides in order to concentrate silicoflagellates and eliminate the clay fraction of the sediment. The sieve sizes used varied with sediment type and were either $38 \mu \mathrm{m}, 45 \mu \mathrm{m}$, or $63 \mu \mathrm{m}$ size, or a combination of the three sizes. Slides were prepared of all sieved fractions; those intervals were sieved fractions were examined are indicated in the species occurrence tables by an asterisk beside the sample designations. Sieved fractions were examined to delineate species ranges more accurately. For a more detailed discussion of the advantage of this technique the reader is referred to Gombos and Ciesielski (this volume).

The authors shared the responsibility of examining the silicoflagellate assemblages of Leg 71 sediments as follows: Hole 511, upper Eocene-lower Oligocene, Shaw; Pliocene-Holocene, Ciesielski; Hole 512, middle Eocene, Shaw; middle Miocene-Holocene, Ciesielski; Hole 513, Ciesielski; Hole 514, Ciesielski.

Two separate techniques were employed to determine the abundance of silicoflagellates in Leg 71 sediments. Shaw made a quantitative determination of silicoflagellate abundances in 95 samples from the middle Eocene sediments of Hole 512 and upper Eocene-lower Oligocene sediments of Hole 511 to assist in determining the limits of species variability. Species abundances represent either the total number of specimens present on the entire slide or the number present from the $\sim 300$ specimens counted. Specimen counts were made using a Leitz Dialux 20 light microscope at a magnification of $125 \times$. All specimens which consisted of more than half a skeleton were counted. Sieved samples of core-catcher sediments were examined to check for rare species not present in strewn (whole-fraction) slides.

Ciesielski used a slightly different technique in his tabulation of silicoflagellate abundances in the lower Oligocene-lower Miocene of Hole 513A. Both sieved ( $>45 \mu \mathrm{m})$ and whole-fraction slides of each sample were examined because of the stratigraphic importance of large silicoflagellate species (e.g., Corbisema archangelskiana) and the high clay content of most samples. Whole-fraction and sieved-fraction slides were examined by the same technique that Shaw used, except that a maximum of 150 specimens was counted per slide, resulting in a count of 300 specimens per interval.

Ciesielski recorded the abundance of silicoflagellate taxa in all other stratigraphic intervals he examined as relative abundances. Relative abundances are based on an examination of the entire whole-fraction slide (at $125 \times$ ) and are designated as follows: $\mathrm{A}=$ abundant, at least one specimen in every field of view; $\mathrm{C}=$ common, at least one specimen in every two to five fields of view; $\mathrm{F} / \mathrm{C}=$ intermediate between few and common, at least one specimen in every six to ten fields of view; $F=$ few, several specimens observed on the entire slide; $R=$ rare, only one or two specimens observed on the entire slide.

\section{ZONATION}

Eleven silicoflagellate zones and three subzones were recognized in the middle Eocene through Holocene sediments recovered by Leg 71 . Only four of these zones, the middle-upper Miocene Mesocena circulus Zone, upper Miocene Mesocena circulus/M. diodon Zone, $M$. diodon Zone, and the Pliocene Distephanus boliviensis Zone, were previously recognized elsewhere. A new zonation has been constructed for the middle Eocene of Hole 512 and the apparently continuous upper Eocenelowermost Miocene of Holes 511 and 513A. The middle Eocene of Hole 512 is assigned to the Dictyocha grandis Zone and is divided into three subzones. From oldest to youngest, these are the Dictyocha stelliformis Subzone, the D. stelliformis-M. apiculata Interval Subzone, and the $M$. apiculata Subzone. Six new zones have been established for the composite upper Eocene-lowermost Miocene section of Holes 511 and 513A: the M. occidentalis Zone, Naviculopsis trispinosa Zone, N. constricta/D. deflandrei Zone, $N$. constricta-Corbisema archangelskiana Interval Zone, C. archangelskiana Zone, and Naviculopsis biapiculata Zone.

Figure 3 compares the Eocene-Oligocene zonation of this study with age correlative zonations of other workers and reveals the lack of a cosmopolitan silicoflagellate zonation for the Eocene-Oligocene. Difficulties we encountered in correlating silicoflagellate zonal schemes of this age from one region to another are related to several factors, including the incompleteness of previously studied stratigraphic sections; definition of previous zones based on rare, sporadic, or poorly silicified species; and establishment of new zones based on few samples from short stratigraphic sections.

The silicoflagellate zonation of the middle Eocene through lower Miocene is presented in Figures 4 and 5 . Figure 4 presents the composite upper Eocene-lower Miocene stratigraphic section of Holes 511 and 513A. The two holes are correlated on the basis of the extinction or highest stratigraphic occurrence of the calcareous nannofossil Isthmolithus recurvus. In Hole 513A the $I$. recurvus datum occurs at the top of Core 31, in Hole 511 at the top of Core 4 (Wise, this volume). The occurrence of the $I$. recurvus datum and other datums in the lower portion of Hole 513A and upper portion of Hole 511 (this chapter; Gombos and Ciesielski, this volume) indicate that Cores 28 through 33 of Hole 513A are stratigraphic correlatives of Cores 1 through 6 of Hole 511 (Fig. 5).

The presence of siliceous and calcareous microfossils throughout the upper Eocene-lower Miocene of Sites 511 and 513A enabled us to correlate the silicoflagellate zonation of this chapter with zonal schemes based on foraminifers, calcareous nannofossils, radiolarians, and diatoms. These correlations are not discussed in the text but instead are presented in Figures 6 and 7, later.

\section{Dictyocha grandis Range Zone}

Authors. Shaw and Ciesielski, this chapter.

Base. Lowest occurrence of Dictyocha grandis n. $\mathrm{sp}$.

Top. Highest occurrence of $D$. grandis.

Remarks. The uppermost and lowermost occurrences of the named species occur at a disconformity and the base of the hole, respectively. The local range of $D$. grandis in Hole 512 does not, therefore, represent the entire stratigraphic range of this species. Correlation of this zone to magnetostratigraphy does indicate, however, a minimum range of 3.0 m.y. for the species, certainly a sufficient length of time to make the zone easily recognized in age-equivalent sections elsewhere.

We select $D$. grandis as the zonal indicator species because even though it constitutes a small percentage of the total assemblage it occurs frequently in almost all samples. Because of its large size $(\sim 100-150 \mu \mathrm{m}, 4-5 \times$ the size of $D$. hexacantha) and robust skeleton it is quickly recognized in a scan of several fields of view with a low magnification objective $(10 \times)$; therefore, it 


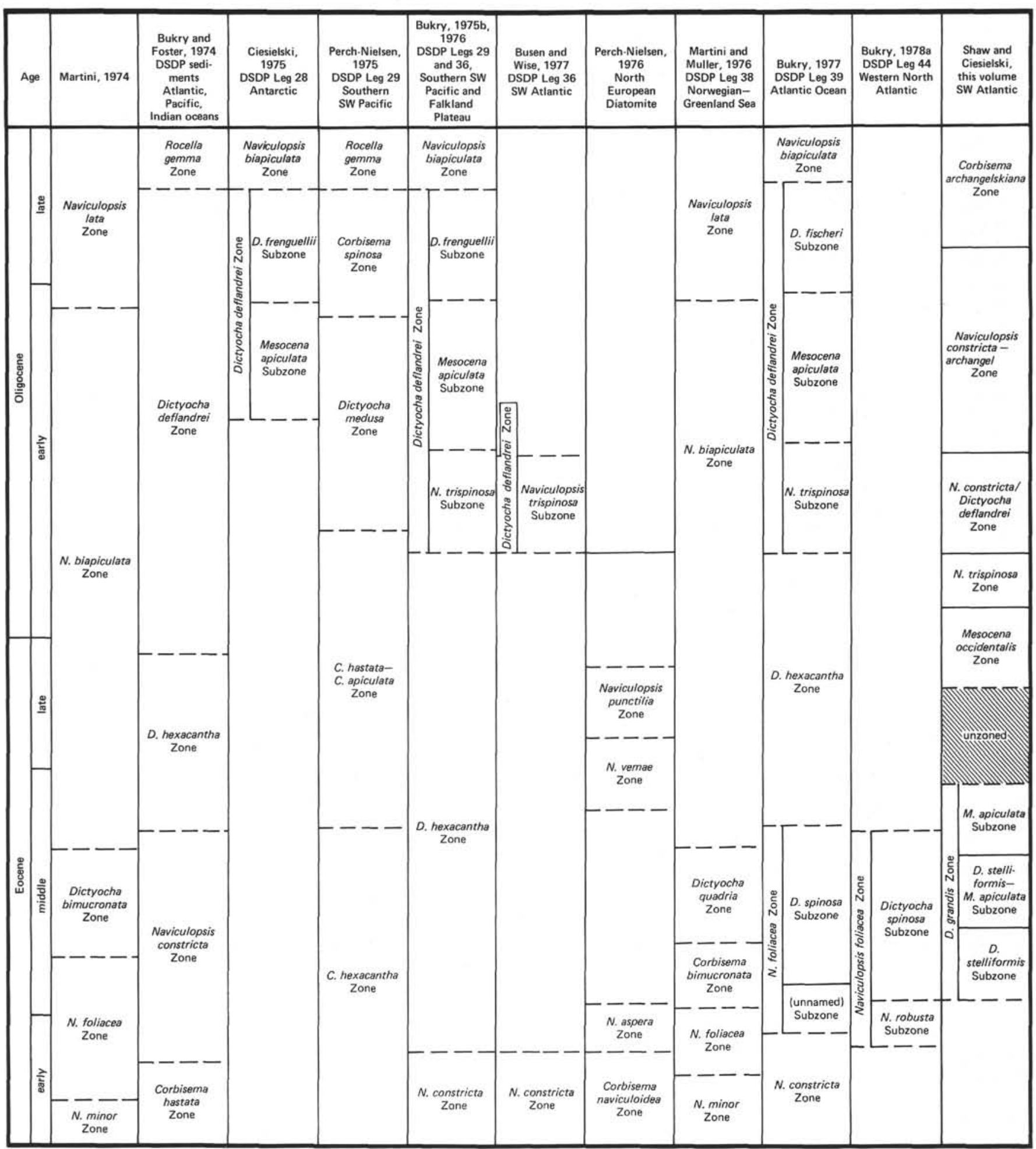

Figure 3. Comparison of the Eocene/Oligocene silicoflagellate zonation of this study and those of other authors.

can be recognized as quickly as smaller, more common species can be at higher magnifications $(40 \times$ or $100 \times)$. In addition, the more common species (e.g., Naviculopsis biapiculata) are long-ranging and unsuitable for stratigraphic subdivision of the middle Eocene.

This is the first recording, in the scientific literature, of $D$. grandis n.sp., which is common to abundant throughout the middle Eocene of Site 512. This species has also been noted from Eocene piston cores of the Falkland Plateau by Gombos (pers. comm. to P. Ciesielski, 1981). The Eocene section recovered at Site 512 represents a portion of the stratigraphic record which has been sampled only rarely (Table 1). Further sampling of the middle Eocene will be necessary to document further the total range of $D$. grandis.

Age. Middle Eocene, 40.9-43.7 Ma. 


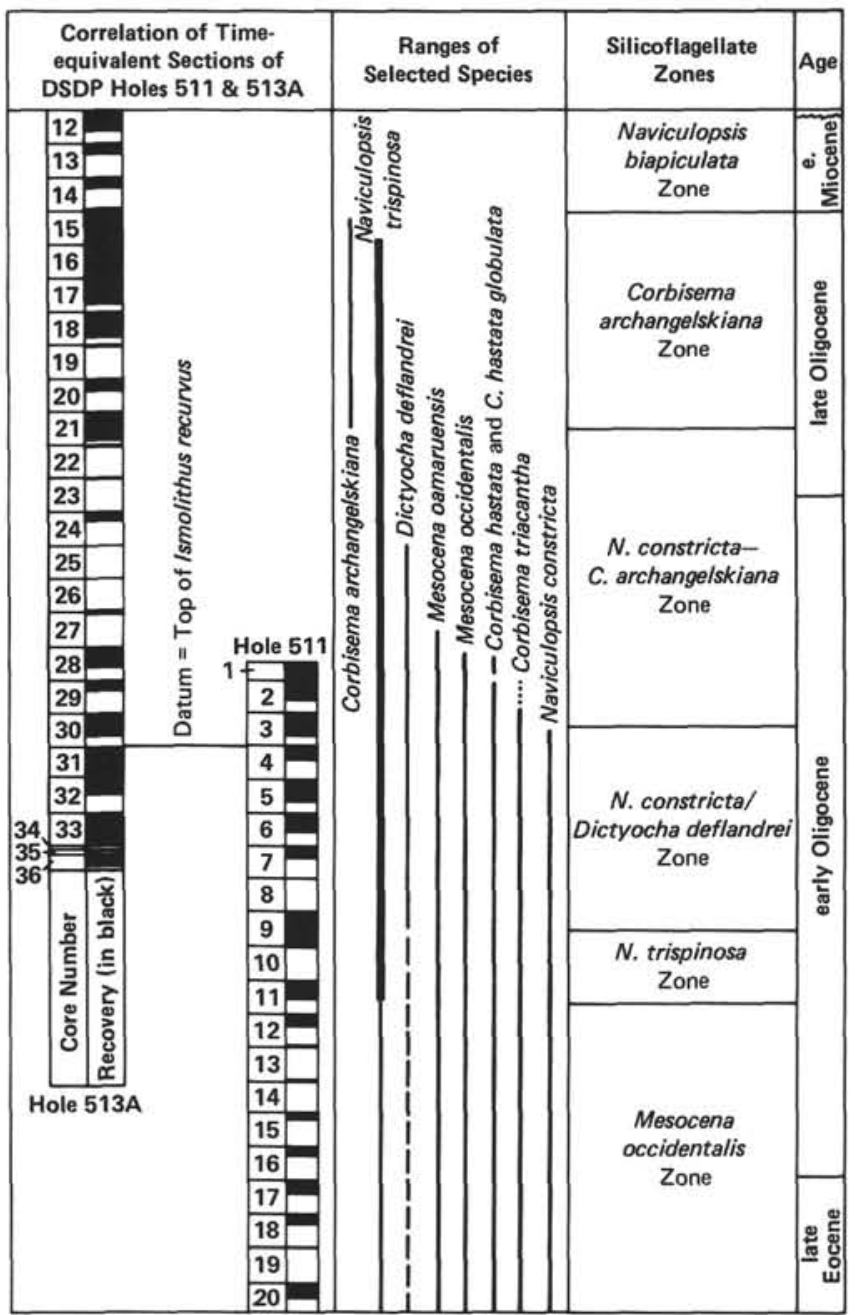

Figure 4. Correlation of the lower Oligocene to lower Miocene sections of Holes 511 and 513A with the ranges of selected silicoflagellates and the designated silicoflagellate biostratigraphic zones. Correlation of Holes 511 and 513A based on the occurrence of the Ismolithus recurvus datum.

Characteristics. Characterized by the presence of Dictyocha grandis n.sp. Species which are consistently present, in varying abundance, include Corbisema apiculata, C. hastata globulata, C. triacantha, Dictyocha aspera aspera, D. fibula, D. spinosa, Distephanus speculum s.1., Mesocena oamaruensis, M. occidentalis, Naviculopsis biapiculata, $N$. constricta, and $N$. foliacea. Also present, less consistently and in lower abundance (generally $<2 \%$ ), are $C$. bimucronata, $C$. flexuosa, $C$. geometrica, C. hastata hastata, Dictyocha anguinea $\mathrm{n}$. sp., $D$. aspera martinii, $D$. deflandrei, $D$. hexacantha, D. pentagona, D. stelliformis n.sp., Distephanus antiquus, D. crux crux, D. quinquangellus, M. apiculata, $N$. nordica hyalina, and $N$. trispinosa.

Within the Dictyocha grandis Zone three subzones are identified (Fig. 5). The lowermost is the $D$. stelliformis Subzone, the top of which is defined at the highest occurrence of $D$. stelliformis n.sp. in Sample 512-17-1, $28-30 \mathrm{~cm}$, and the base at the lowest occurrence of $D$. grandis in Sample 512A-2-5, 93-94 cm, the basal sample of Hole 512A. D. stelliformis generally constitutes 1-
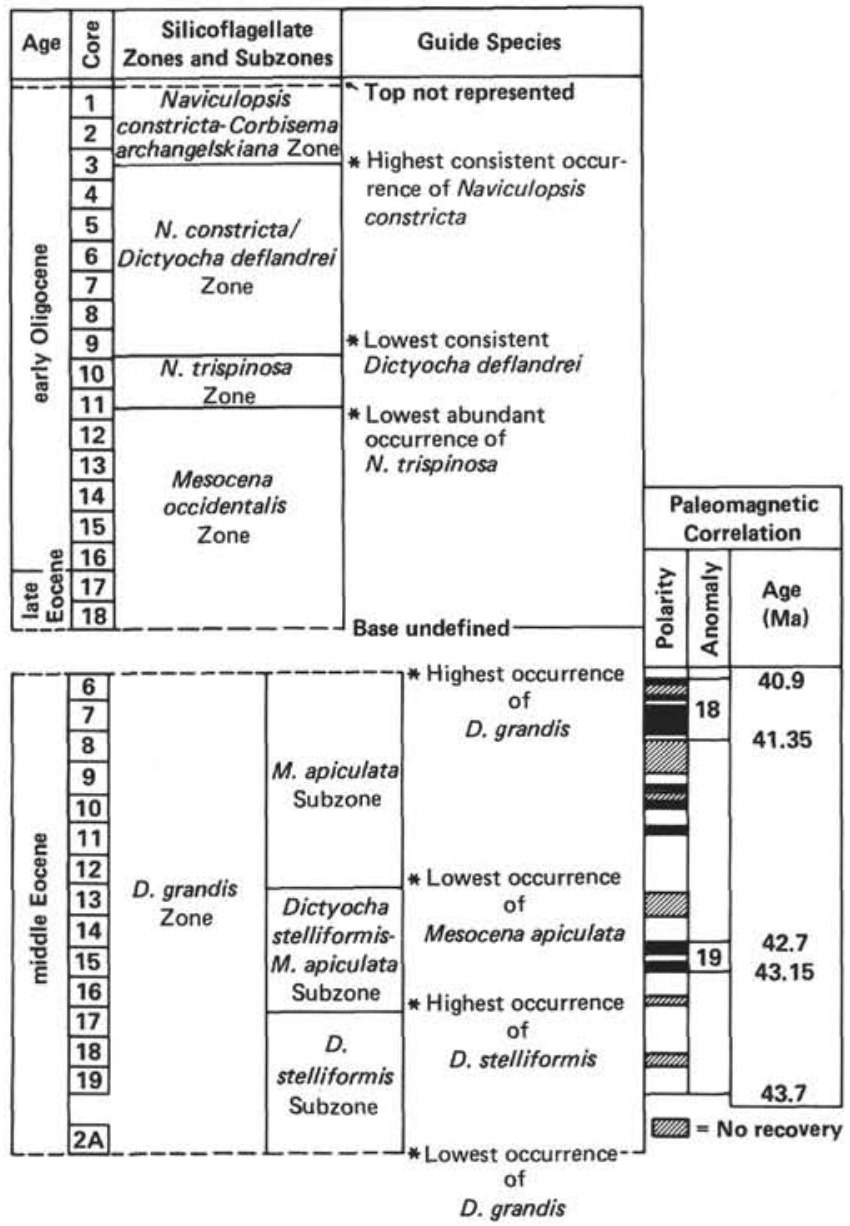

Figure 5. Silicoflagellate zones, subzones, and guide species datums from the Paleogene of Holes 511 (above) and 512 (below). Hole 512 is correlated to the magnetic polarity sequence as identified by Ledbetter (this volume).

Table 1. DSDP reports on middle Eocene silicoflagellates, Legs 1-71.

\begin{tabular}{clccc}
\hline $\begin{array}{c}\text { DSDP Leg and } \\
\text { Location }\end{array}$ & \multicolumn{1}{c}{ Author(s) } & Site & $\begin{array}{c}\text { No. } \\
\text { Cores }\end{array}$ & $\begin{array}{c}\text { No. } \\
\text { Samples }\end{array}$ \\
\hline $\begin{array}{c}\text { Leg 29, southern } \\
\text { southwest Pacific }\end{array}$ & $\begin{array}{l}\text { Bukry, 1975b } \\
\text { Perch-Nielsen, 1975 }\end{array}$ & 283 & 1 & 2 \\
$\begin{array}{c}\text { Leg 38, Norwegian- } \\
\text { Greenland Sea }\end{array}$ & $\begin{array}{l}\text { Bukry, 1976b } \\
\text { Martini and Müller, } \\
\quad 1976\end{array}$ & 339 & 1 & 1 \\
$\begin{array}{l}\text { Bukry, 1977 } \\
\text { Leg 39, Western }\end{array}$ & 343 & 2 & 3 \\
$\quad$ North Atlantic & Bukry, 1978b & 386 & 4 & 10 \\
$\begin{array}{c}\text { Leg 43, Western } \\
\quad \text { North Atlantic }\end{array}$ & Bukry, 1978 & 386 & 2 & 4 \\
$\begin{array}{c}\text { Leg 44, Western } \\
\quad \text { North Atlantic }\end{array}$ & Bukry, 1978a & $390 \mathrm{~A}$ & 2 & 6 \\
$\begin{array}{l}\text { Leg 71, Southwest } \\
\text { Atlantic }\end{array}$ & This chapter & 512 & 15 & 41 \\
\hline
\end{tabular}

$2 \%$ of the subzonal assemblage but, as with $D$. grandis, occurs frequently in all preparations and is quickly recognized because of its large size and robust skeleton.

The middle subzone of the $D$. grandis Zone is the $D$. stelliformis-M. apiculata Interval Subzone. The top and base of this subzone are defined, respectively, by the lowest occurrence of $M$. apiculata and the highest oc- 
currence of $D$. stelliformis n.sp. Few $D$. anguinea n.sp. are present in the sieved core-catcher slides throughout the subzone. The $D$. stelliformis-M. apiculata Subzone is present in Hole 512 from Sample 512-16-2, 15-17 cm through Sample 512-13-2, 43-45 cm.

The $M$. apiculata Subzone is the youngest of the $D$. grandis subzones. Its top is the highest occurrence of $D$. grandis, the disconformity between Core 5 and Core 6 , and its base is defined by the lowest occurrence of $M$. apiculata. At Hole 512, the M. apiculata Subzone is found in Sample 512-13-1, 42-44 cm through Sample $512-6-1,78-80 \mathrm{~cm}$.

Reference section. Site $512 ; 49^{\circ} 52.19^{\prime} \mathrm{S}, 40^{\circ} 50.71^{\prime} \mathrm{W}$.

Occurrence of zone. Sample 512A-2-5, 93-94 cm through Sample 512A-2-1, 93-94 cm and Sample 512$19-3,27-29 \mathrm{~cm}$ through Sample 512-6-1, 78-80 cm.

Correlation. Relatively few deep sea middle Eocene silicoflagellate localities have previously been studied (Table 1) and all of these are short stratigraphic sections of no more than four cores. For this and other reasons a number of problems were encountered in correlating the middle Eocene of Hole 512 with established middle Eocene silicoflagellate zones.

Bukry (1977) recognizes two middle Eocene silicoflagellate zones, the Naviculopsis foliacea Zone and the Dictyocha hexacantha Zone. Bukry (1977) defines the lower and upper boundaries of the $N$. foliacea Zone by the first occurrence of $N$. foliacea and the first occurrence of $D$. hexacantha, respectively. Bukry uses the first occurrence of $D$. spinosa to further subdivide the $N$. foliacea Zone into a lower $N$. robusta Subzone (Bukry, 1978a) and upper D. spinosa Subzone (Bukry, 1977, 1978a, b).

$N$. foliacea is present throughout the middle Eocene section of Hole 512 and rare $D$. hexacantha occur above Sample 512-9-1, 92-94 cm. The interval above the initial occurrence of $D$. hexacantha, Sample 512-9-1, 92-94 cm through Samples 512-6-1, 78-80 cm, appears to correlate to the D. hexacantha Zone of Bukry and Foster (1974). The remainder of the $D$. grandis Zone below Sample 512-9-1, 92-94 cm contains D. spinosa throughout and, therefore, should correlate with the $D$. spinosa Subzone of the $N$. foliacea Zone.

In this chapter, we establish the $D$. grandis Zone and reject other middle Eocene silicoflagellate zones for several reasons. First, our $D$. grandis Zone probably represents a portion of the $D$. hexacantha and $N$. foliacea zones not previously recovered elsewhere, because the Hole 512 assemblage contains a number of species not present in previously described sections. Furthermore, we cannot definitively determine the first occurrence of $D$. hexacantha in Hole 512 because of its rarity and cannot, therefore, confidently recognize the $N$. foliacea/D. hexacantha zonal boundary. We recognize several major problems in using $D$. hexacantha as a zonal indicator.

$D$. hexacantha was first used as an Eocene zonal marker by Bukry and Foster (1973), who defined the middle Eocene $D$. hexacantha Zone as the interval represented by the total range of this species. Other workers (Fig. 3) have subsequently used the first and/or last occurrence of $D$. hexacantha in other zonal schemes of the Eocene, even though its occurrence is often sporadic and rare. In the middle Eocene of Hole 512, D. hexacantha occurs occasionally and is rare, never more than $2 \%$. Rare $(<1 \%) D$. hexacantha are also recorded in two samples from uppermost upper Eocene and lowermost lower Oligocene sediments of Hole 511. Specimens observed here and elsewhere are small, extremely hyaline, and susceptible to dissolution. Through $D$. hexcantha does have a limited stratigraphic range, it is a species which is easily destroyed or overlooked, and the full extent of its range is difficult to delineate property. For these reasons, we believe $D$. hexacantha should not be used as a zonal indicator when other more suitable species may be used; it is not used as such in this study. If $D$. hexacantha is utilized as a zonal indicator elsewhere, record of its occurrence should be based on detailed sampling and analysis of the studied stratigraphic section.

Correlation with magnetostratigraphy. Because Hole 512 was recovered undisturbed by hydraulic piston coring, it is possible to assign absolute ages to the zonal boundaries presented here (Fig. 5) by correlating the stratigraphy to Ledbetter's (this volume) magnetostratigraphic record of the Hole 512 section. Ledbetter has correlated the middle Eocene section of Hole 512 with the time scale from Magnetic Anomaly 18 to slightly younger than Magnetic Anomaly 20 (40.9-43.7 Ma). Anomaly 18 occurs in the upper portion of the Mesocena apiculata Subzone and Anomaly 19 occurs in the mid to lower portion of the Dictyocha stelliformis- $M$. apiculata Interval Subzone. By interpolation it is possible to assign an age of $\sim 42.4 \mathrm{Ma}$ to the boundary between these two subzones. In a similar fashion, an age of $43.0 \mathrm{Ma}$ is assigned to the boundary between the $D$. stelliformis Subzone and the D. stelliformis-M. apiculata Interval Subzone.

\section{Mesocena occidentalis Zone}

Author. Shaw, this chapter.

Base. Undefined.

Top. Lowermost abundant occurrence $(>10 \%)$ of Naviculopsis trispinosa.

Age. Late Eocene-early Oligocene.

Characteristics. Naviculopsis trispinosa never exceeds $10 \%$ of the silicoflagellate population in this zone or in the middle Eocene Dictyocha grandis Zone of Hole 512.

Common species in the zone include Corbisema hastata globulata, C. triacantha, Distephanus boliviensis, $D$. crux crux, Mesocena apiculata, M. oamaruensis, $M$. occidentalis, $N$. biapiculata, and $N$. constricta. Species which are present less consistently and in varying abundance include $C$. apiculata, $C$. bimucronata, C. flexuosa, C. geometrica, C. hastata hastata, Dictyocha aspera aspera, $D$. deflandrei, $D$. fibula, $D$. cf. D. fibula, $D$. hexacantha, D. pentagona, $D$. cf. D. stelliformis, Distephanus crux paulii, and $D$. quinquangellus.

Reference section. Site $511 ; 51^{\circ} 00.28^{\prime} \mathrm{S}, 46^{\circ} 58.30^{\prime} \mathrm{W}$.

Occurrence of zone. Sample 511-11,CC through Sample 511-18,CC.

Correlation. It is impossible to recognize age-equivalent silicoflagellate zones of other workers in Hole 511 
because of the scarcity or absence of their zonal indicator species, including Dictyocha quadria, Naviculopsis punctilia, N. lauta, and D. hexacantha. Rare $D$. hexacantha in Samples 511-17,CC and 511-18-2, 18-20 cm suggest that this portion of the Mesocena occidentalis Zone may correspond to the upper portion of the $D$. hexacantha Zone recognized by Bukry and Foster (1974) and Bukry (1975a, 1976a, 1977). As we discussed earlier, the $D$. hexacantha Zone was not employed here because of difficulties in recognizing the natural range of this species.

\section{Naviculopsis trispinosa Oppel Zone}

Author. Shaw, this chapter.

Base. Lowest abundant $(>10 \%)$ occurrence of $\mathrm{Navi}$ culopsis trispinosa.

Top. Lowest consistent occurrence of Dictyocha deflandrei.

Age. Early Oligocene.

Characteristics. This zone is characterized by the abundant occurrence of Naviculopsis trispinosa and the absence of consistently occurring Dictyocha deflandrei. Other species consistently present in varying amounts include Corbisema hastata globulata, C. triacantha, D. aspera aspera, D. cf. D. fibula, Distephanus crux crux, D. quinquangellus, Mesocena apiculata, M. occidentalis, $N$. biapiculata, and $N$. constricta. Species generally scarce to few and present less consistently include C. hastata hastata, Dictyocha deflandrei, D. fibula, Distephanus boliviensis, and $M$. oamaruensis.

Reference section. Site $511 ; 51^{\circ} 00.28^{\prime} \mathrm{S}, 46^{\circ} 58.30^{\prime} \mathrm{W}$.

Occurrence of zone. Sample 511-11-4, 5-6 cm through Sample 511-9-5, 80-81 cm.

Correlation. The stratigraphic interval of this zone and the Mesocena occidentalis Zone is probably a portion of the uppermost Eocene-lowermost Oligocene not previously analyzed for silicoflagellates. Bukry and Foster (1974) defined the boundary between the Dictyocha deflandrei and $D$. hexacantha zones by the last common occurrence of $D$. hexacantha and the first common occurrence of $D$. deflandrei. At DSDP Site 283, Bukry (1975a) found both of the above datums occurring between 283-7-6, $125 \mathrm{~cm}$ and 283-8-1, $75 \mathrm{~cm}$. Since the Naviculopsis trispinosa and $M$. occidentalis zones occur well above the last common occurrence of $D$. hexacantha (it occurs only rarely in and below Sample 511-17, $\mathrm{CC}$ ) and below the first occurrence of $D$. deflandrei (not at the same stratigraphic level as in Hole 283), it appears that the entire $N$. trispinosa and $M$. occidentalis zones of Hole 511 occur at a stratigraphic position between Bukry's (1975a) D. hexacantha and $D$. deflandrei zones. If this assertion is correct, the boundary between the $D$. hexacantha and $D$. deflandrei zones in Hole 283 is a disconformable one.

\section{Naviculopsis constricta/Dictyocha deflandrei Concurrent Range Zone}

Author. Shaw and Ciesielski, this chapter.

Base. Lowest consistent occurrence of Dictyocha deflandrei.
Top. Highest consistent occurrence of Naviculopsis constricta.

Age. Early Oligocene.

Characteristics. The Naviculopsis constricta Zone is characterized by the consistent occurrence of $N$. constricta and $D$. deflandrei. Other species generally common and consistently present throughout most of the zone in Holes 511 and 513A include Corbisema hastata globulata, C. triacantha, Distephanus crux crux, D. quinquangellus, Mesocena apiculata, M. occidentalis, $N$. biapiculata, and $N$. trispinosa. Species which occur less consistently and are generally rare to sparse include Corbisema apiculata, C. geometrica, C. hastata hastata, Dictyocha alta, D. aspera aspera, D. aspera martinii, D. fibula, $D$. pentagona, $D$. spinosa, $D$. sp. 1 , Distephanus boliviensis, $M$. oamaruensis, and $N$. punctilia.

Reference section. Site $511 ; 51^{\circ} 00.28^{\prime} \mathrm{S}, 46^{\circ} 58.30^{\prime} \mathrm{W}$.

Occurrence of zone. Sample 511-9-4, 80-81 cm through Sample 511-3-4, 65-55 cm and Sample 513A-337, 55-57 cm through Sample 513A-31-2, 21-23 cm.

Correlation. We find it difficult to correlate the Naviculopsis constricta/Dictyocha deflandrei Zone to any of the three subzones of the lower Oligocene $D$. deflandre $i$ Zone described by Ciesielski (1975), Bukry (1975a, 1975b, 1976a, 1977), and Busen and Wise (1977) (Fig. 3 ). It appears that the top of the $N$. constricta/D. deflandrei Zone correlates to the base of the Mesocena apiculata Subzone (Bukry, 1975b) of the D. deflandrei Zone because the highest occurrence of $N$. constricta is coincident with these boundaries (Bukry, 1975a). We find an abundance increase of $M$. apiculata, roughly beginning at the top of our $N$. constricta/D. deflandrei Zone, which may correspond to the acme of this species used by Bukry (1975b) to define the base of his $M$. apiculata Subzone. Definitive correlation to the $M$. apiculata acme referred to by Bukry (1975b) is not possible because our detailed work on the lengthy Oligocene section of Hole 511 reveals several increases in the abundance of this species and no single acme. We believe, therefore, the present definition of the base of the $M$. apiculata Subzone is unsuitable. If this subzone is to be maintained for use in other regions, we suggest that the uppermost occurrence of $N$. constricta be used to define its base.

The base of the $N$. constricta/D. deflandrei Zone, defined here as the first consistent occurrence of $D$. deflandrei, may correlate with the base of Bukry's (1975a) $D$. deflandrei Zone, recognized by him to be the consistent occurrence of $D$. deflandrei above the last common occurrence of $D$. hexacantha. If such a correlation is correct, however, the base of our $N$. constrictal $D$. deflandrei Zone should also correlate to the base of the $N$. trispinosa Subzone (Bukry, 1975b) of Bukry and Foster's (1974) D. deflandrei Zone. The $N$. trispinosa Subzone of Bukry (1975b) is not identifiable in our material because $N$. constricta is not dominant over $M$. apiculata and because $N$. trispinosa is a major instead of a minor component of the assemblage.

Busen and Wise (1977) partially defined the $N$. trispinosa Subzone of the $D$. deflandrei Zone by the initial 
occurrence of $N$. trispinosa, thus making the initial occurrence of $N$. trispinosa coincident with the initial consistent occurrence of $D$. deflandrei. The results of this study reveal Naviculopsis trispinosa present throughout the middle Eocene of Hole 512, well below the early Oligocene initial consistent occurrence of $D$. deflandrei.

In summary, our $N$. constricta/D. deflandrei Zone correlates with the lower portion of Bukry and Foster's $D$. deflandrei Zone. We cannot recognize the $N$. trispinosa Subzone, and we question its stratigraphic value, because it is bounded at the base by a disconformity (see discussion of the $N$. trispinosa Zone) and bounded at the top by one of several known abundance increases of $M$. apiculata, any of which could be mistaken for an acme in an incomplete section. We are also unable to recognize the $N$. trispinosa Subzone by the relative abundance of $N$. constricta to $M$. apiculata or by the initial occurrence of $N$. trispinosa.

\section{Naviculopsis constricta-Corbisema archangelskiana Interval Zone}

Author. Bukry, 1974; modified, Ciesielski and Shaw, this chapter.

Base. Highest occurrence of Naviculopsis constricta.

Top. Lowest occurrence of common Corbisema archangelskiana.

Age. Late early Oligocene-early late Oligocene.

Characteristics. This Interval Zone is present in its entirety in Hole 513A, whereas only the lower portion of the zone is present at Hole 511 (Figs. 4-7). In both holes the zone is characterized by consistent and abundant Naviculopsis trispinosa, $N$. biapiculata, Mesocena apiculata, and Distephanus crux crux. Other species occurring sporadically or only ranging partially through the zone, with varying abundances, include Corbisema apiculata, C. flexuosa, C. geometrica, C. hastata globulata, C. hastata hastata, C. triacantha, Dictyocha aspera aspera, D. aspera martinii, D. pentagona, Distephanus boliviensis, $D$. quinquangellus, $M$. oamaruensis, and $M$. occidentalis.

Many species exhibit their last occurrence in the newly defined $N$. constricta-C. archangelskiana Zone of Hole 513A. These include $C$. apiculata, C. hastata globulata, $C$. hastata hastata, and $M$. occidentalis (all in Sample 513A-29-2, 20-22 cm); D. aspera martinii and $M$. oamaruensis (Sample 513A-28-1, 17-19 cm); and $D$. deflandrei (Sample $51325, \mathrm{CC}$ ). A new species, D. alta, has its highest and most abundant occurrence in Sample 513A-26,CC. Common $M$. bispicata n.sp. is found only in Sample 513A-26,CC.

This zone is characterized by the single greatest change in the relative generic composition of the entire middle Eocene and late Eocene-early Miocene. Within the middle to upper portion of the zone the genera Corbisema, Dictyocha, and Mesocena (with the exception of $M$. apiculata) diminish greatly as components of the silicoflagellate assemblage. The upper Oligocene portion of the zone is dominated by Distephanus spp., $M$. apiculata, $N$. biapiculata, and $N$. trispinosa.

Reference sites. Hole $511 ; 51^{\circ} 00.28^{\prime} \mathrm{S}, 46^{\circ} 58.30^{\prime} \mathrm{W}$. Hole $513 \mathrm{~A} ; 47^{\circ} 34.99^{\prime} \mathrm{S}, 24^{\circ} 36.40^{\prime} \mathrm{W}$.
Occurrence of zone. Samples 511-3-3, 65-66 cm through 511-1-4, 15-16 cm and Samples 513A-30-2, 29$31 \mathrm{~cm}$ through 513A-22-1, 14-16 cm.

Correlation. For reasons previously discussed in our description of our Naviculopsis constricta/Dictyocha deflandrei Zone, the base for the $N$. constricta-Corbisema archargelskiana Interval Zone is probably correlative to the base of the Mesocena apiculata Subzone of Bukry and Foster's $D$. deflandrei Zone. In our interval it is not possible to recognize the $M$. apiculata Subzone, $D$. frenguellii Subzone, or $D$. fischeri Subzone of the $D$. deflandrei Zone because of the absence of $D$. fischeri, the scarcity of $D$. frenguellii, and the lack of a single $M$. apiculata acme. No correlation is made with the Oligocene silicoflagellate zones of Martini and Müller (1976) or Perch-Nielsen (1975) because of the absence of their indicator species in Holes 511 and 513A.

\section{Corbisema archangelskiana Range Zone}

Author. Ciesielski, this chapter.

Base. Lowest occurrence of Corbisema archangelskiana.

Top. Highest occurrence of Corbisema archangelskiana.

Age. Late Oligocene.

Characteristics. The Corbisema archangelskiana Zone is characterized by the consistent presence of few to common $C$. archangelskiana, Mesocena apiculata, Distephanus boliviensis hemisphaericus, and D. quinquangellus, common D. crux crux, and a few D. speculum and $D$. boliviensis. Occurring sporadically and rare to few in abundance are $C$. triacantha, Dictyocha frenguellii, $D$. cf $D$. frenguellii, D. pentagona, D. quadria, and Naviculopsis trispinosa. Macrora barbadensis and $M$. stella occur in the upper portion of the zone. The last occurrence of $N$. trispinosa occurs in Sample 513A-15-3, $119-121 \mathrm{~cm}$, immediately below the Oligocene/Miocene boundary.

Reference site. Hole 513A; $47^{\circ} 34.99^{\prime} \mathrm{S}, 24^{\circ} 38.40^{\prime} \mathrm{W}$.

Occurrence of zone. Sample 513A-21-1, 70-72 cm through Sample 513A-15-3, 119-121 cm.

Correlation. Correlation of this zone to the foraminiferal and calcareous zonations (Wise, this volume; Basov and Krasheninnikov, this volume) of this site reveals that the Corbisema archangelskiana Zone encompasses most of the upper Oligocene (Fig. 3) and represents the most complete upper Oligocene section yet recovered in the southern high latitudes. The upper boundary of the zone coincides with the Oligocene/Miocene boundary.

The $C$. archangelskiana Zone is equivalent to the basal portion of DSDP Hole 278, which Perch-Nielsen (1975) assigns to the Rocella gemma ( $=R$. gelida) Zone and $C$. spinosa Zone. This is verified by the presence in Hole 278 of an acme of $R$. gelida (now considered a diatom) in Sample 278-31-2, $110 \mathrm{~cm}$ and the range of $R$. vigilans from Sample 278-32-3, 50-51 cm through 278$33-1,50-51 \mathrm{~cm}$. Correlation of the $C$. archangelskiana Zone to the diatom zonation of Gombos and Ciesielski (this volume) indicates that the acme of $R$. gelida and the entire range of $R$. vigilans occurs within the upper 
portion of the C. archangelskiana Zone. Correlation of the $C$. archangelskiana Zone of Hole 513A with Hole 278 suggests that the zone of poor preservation below the base of the zone in Hole 513A (Cores 22-25) corresponds to a similar zone of poor preservation at the base of Hole 278 (Cores 32-34).

An abbreviated section of late Oligocene sediment in Cores 267B-4 and 267B-5 also appears to be correlative to our $C$. archangelskiana Zone. Sediments from these cores contain $C$. archangelskiana and the diatom $R$. vigilans (Bukry, 1975a; Ciesielski, 1975), thus indicating a stratigraphic position in the middle portion of the $C$. archangelskiana Zone.

Bukry (1975a) assigns the upper Oligocene silicoflagellate assemblage of Hole 267B to his Naviculopsis biapiculata Zone (Bukry, 1975b), the base of which is defined by the first common occurrence of Naviculopsis biapiculata. In Leg 71 sediments, common N. biapiculata occur much lower in the section than reported by Bukry (1975b), occurring commonly throughout the Oligocene, upper Eocene, and middle Eocene.

\section{Naviculopsis biapiculata Partial Range Zone}

Authors. Bottom: Bukry, 1975b; revised Ciesielski, this volume. Top: Bukry, 1975b.

Base. Highest occurrence of Corbisema archangelskiana.

Top. Highest occurrence of Naviculopsis biapiculata.

Age. Early Miocene.

Characteristics. The entire Naviculopsis biapiculata Zone is not present in Hole 513A; however, the portion represented is characterized by common $N$. biapiculata, Distephanus boliviensis hemisphaericus, and D. crux crux. Also present, less consistently and in lower abundance are $D$. boliviensis, $D$. quinquangellus, $D$. speculum, Macrora barbadensis, and Mesocena apiculata.

Reference section. Hole $513 \mathrm{~A}, 47^{\circ} 34.99^{\prime} \mathrm{S}, 24^{\circ} 38.40^{\prime}$ W.

Occurrence of zone. Sample 513A-12-3, 128-130 cm through 513A-14-6, 46-48 cm.

Correlation. Bukry (1975b) defines the base of the upper Oligocene Naviculopsis biapiculata Zone as the first common occurrence of $N$. biapiculata. Within Leg 71 sediments, common $N$. biapiculata are found throughout most of the middle Eocene and upper Eocene through lower Miocene; therefore, the first common $N$. biapiculata is not a suitable upper Oligocene biostratigraphic marker in our study area. We substitute the last Corbisema archangelskiana as the definition for the base of the $N$. biapiculata Zone, thus making the zone earliest Miocene in age.

In Hole 513A, the acme of the diatom Rocella gelida occurs immediately below the $N$. biapiculata Zone. Bukry (1975a) notes the acme of $R$. gelida (=Bukry's $R$. gemma) within his $N$. biapiculata Zone; therefore, our $N$. biapiculata Zone correlates with the portion of his zone above the acme of $R$. gelida.

\section{Mesocena circulus Partial Range Zone}

Authors. Bottom: Ciesielski, 1975. Top: Busen and Wise, 1977.
Base. Lowest consistent occurrence of Mesocena circulus.

Top. Lowest occurrence of Mesocena diodon.

Age. Late middle-late Miocene.

Zonal assemblage. Mesocena circulus is rare or sparse throughout most of the zone at Hole 512, occurring commonly only in Samples 512-5-1, 61-63 cm and 512$5-2,70-72 \mathrm{~cm}$. Few other silicoflagellates are present throughout most of the zone, except in Samples 512-4-3, 3-5 $\mathrm{cm}$ and 512-5-2, 61-53 cm, where Dictyocha spp. are abundant.

Occurrence of zone. In Leg 71 materials the Mesocena circulus Zone occurs only in Sample 512-1-1, 100$101 \mathrm{~cm}$ through 512-5,CC.

Correlation. The Mesocena circulus Zone was previously noted in other Maurice Ewing Bank sediments recovered by several piston cores (Ciesielski, 1978) and DSDP Hole 329. To the west-southwest of Hole 512, where the Miocene sediments of the Maurice Ewing Bank are much thicker, the $M$. circulus Zone was encountered in Samples 329 13-3, 30-32 cm through 329$15-5,30-32 \mathrm{~cm}$ (Busen and Wise, 1977).

At Hole 512 the boundary between the Nitzschia denticuloides and Denticulopsis lauta/D. hustedtii diatom zones occurs within the $M$. circulus silicoflagellate zone. In addition, the first occurrence of the foraminifer Neogloboquadrina acostaensis also occurs within the zone (Thunnell, pers. comm., 1981), in Sample 512-2-1, $106 \mathrm{~cm}$. This foraminifer datum closely approximates the middle/late Miocene boundary, thereby placing this boundary within the $M$. circulus Zone.

Correlation with magnetostratigraphy. Site 512 was hydraulic piston cored and detailed paleomagnetic measurements were made of the recovered sediment by Ledbetter (this volume). The magnetic polarity record of the Hole 512 Mesocena circulus Zone is correlated to early Chron 10 through late Chron 11, representing an interval from $\sim 11.3$ to $11.8 \mathrm{Ma}$ (Ledbetter, this volume, Fig. 2). The middle/upper Miocene boundary occurs within the zone and correlates with lowermost Chron 10 , immediately above the Chron 10 / Chron 11 boundary $(\sim 11.35 \mathrm{Ma})$.

At Hole 512 the upper and lower boundaries of the $M$. circulus Zone are disconformities separating the zone from lower Pliocene and middle Eocene sediments. The incomplete nature of the $M$. circulus Zone at Hole 512 prevents correlation of the upper and lower boundaries of the zone with magnetostratigraphy. On the basis of other paleomagnetically dated piston cores, Ciesielski (this volume) correlates the top of the zone to within late Miocene Chron 9 and within the upper portion of the Denticulopsis hustedtii/D. lauta Diatom Zone. The lower boundary of the $M$. circulus Zone occurs within the middle Miocene Nitzschia denticuloides Diatom Zone at DSDP Site 278.

\section{Mesocena circulus/M. diodon Concurrent Range Zone}

Authors. Busen and Wise, 1977.

Base. Lowest consistent occurrence of Mesocena diodon. 
Top. Highest consistent occurrence of Mesocena circulus.

Age. Late Miocene.

Zonal assemblage. Consistent rare to common Mesocena circulus occur throughout the zone, except in samples from the basal core of the zone (Core 513A-11) where it is found only in Sample 513A-11-2, 53-55 cm and elsewhere as fragments. All other species of silicoflagellates occur sporadically throughout the zone, including rare to common $M$. diodon, rare $M$. elliptica, rare Distephanus crux crux, and few D. boliviensis. Dictyocha spp. are rare to common in several samples; major acmes occur in Samples 513A-7-2, 57-59 and 513A$11-2,53-55$.

Occurrence of zone. In the present study the Mesocena circulus/M. diodon Zone occurs only in Samples $513 \mathrm{~A}-11-2,120-122 \mathrm{~cm}$ through $513 \mathrm{~A}-7-4,70-72 \mathrm{~cm}$.

Correlation. The concurrent range of the species has previously been noted in upper Miocene sediments of DSDP Site 329 (Busen and Wise, 1977) and piston cores (Ciesielski, 1978), all recovered from the Maurice Ewing Bank of the Falkland Plateau. At Site 329 the zone occurs between Samples 329-1-1, 35-37 cm and 329-12-3, $30-32 \mathrm{~cm}$; it is apparently conformable with the Mesocena circulus Zone. This thick Site 329 sequence and occurrences in piston cores of the $M$. circulus $/ M$. diodon Zone are all correlative with the late Miocene Denticulopsis hustedtii/D. lauta Diatom Zone (Ciesielski, 1978,1980 , this volume). The base of the Hole $329 M$. circulus $/ M$. diodon Zone also occurs within the $D$. hustedtii/D. lauta Diatom Zone, the top is at a boundary disconformable with Pliocene sediment.

At Site 513A the lower boundary of the $M$. circulus/ $M$. diodon Zone in Core 11 is disconformable with lower Miocene sediment encountered in Core 12; however, the upper boundary of the zone is conformable with the overlying Mesocena diodon Zone. The upper part of the $M$. circulus $/ M$. diodon zone, between 513A$9-1,69-71 \mathrm{~cm}$ and $513 \mathrm{~A}-7-4,70-72 \mathrm{~cm}$, is correlative with the lower portion of the Denticulopsis hustedtii Diatom Zone (Ciesielski, this volume). The boundary between the $D$. hustedtii/D. lauta Diatom Zone and $D$. hustedtii Diatom Zone is recognized within the $M$. circulus/M. diodon Zone between Samples 513A-10-1, $13-15 \mathrm{~cm}$ and 513A-9-1, 69-71 cm.

Correlation with magnetostratigraphy. Correlation of the base of the $M$. circulus $/ M$. diodon Zone with magnetostratigraphy was given in the previous discussion of the $M$. circulus Zone. Ciesielski (this volume) correlates the top of the $M$. circulus $/ M$. diodon Zone and the top of the Denticulopsis hustedtii/D. lauta Diatom Zone to within paleomagnetic Chron 6 .

\section{Mesocena diodon Partial Range Zone}

Authors. Bottom: Busen and Wise, 1977. Top: Ciesielski, 1975.

Base. Highest consistent occurrence of Mesocena circulus.

Top. Lowest common occurrence of Distephanus pseudofibula.

Age. Late Miocene-early Pliocene.
Zonal assemblage. Rare to few Mesocena diodon occur sporadically throughout the zone. Distephanus boliviensis is the sole species occurring consistently and is sparse to common. Species that occur sporadically, and are generally rare to few include $D$. boliviensis (cannopilean), $D$. crux crux, D. quinquangellus, D. pseudofibula, and D. cf. D. boliviensis. Rare Dictyocha pygmaea and D. pumila are present only in Sample 513-9-5, 66-68 cm. All other Dictyocha spp. occur sporadically in the zone and are rare to few, except between Samples 513-9-7, 6-8 cm and 513A-4-7, 4-6 cm, where they are common.

Correlation. The highest occurrence of the Mesocena diodon Zone has previously been shown to occur in the vicinity of the upper Sidufjall Subchron of the paleomagnetic Gilbert Chron (Ciesielski, 1975, 1978, 1980; Weaver, 1976). Recent study by Ciesielski of Islas Orcadas Piston Core 11-66 places the last occurrence of $M$. diodon near the top of the Sidufjall Subchronozone. It is difficult reliably to place the top of the $M$. diodon Zone in Hole 513 because of the sporadic and scarce occurrence of $M$. diodon; however, its upper occurrence is noted in 513-9-6, 6-8 cm. Since the upper occurrence of M. diodon occurs within the uppermost Denticulopsis hustedtii Zone (Ciesielski, this volume), it is correlative with the lower Gilbert Chronozone, thereby making the sub-Antarctic upper boundary of the $M$. diodon Zone about the same as in the Antarctic.

\section{BIOSTRATIGRAPHY}

\section{Site 511 (Tables 2-4; Figures 4-6, Appendix)}

Hole 511 was continuously drilled to a sub-bottom depth of 632 meters $\left(51^{\circ} 00.28^{\prime} \mathrm{S}, 46^{\circ} 58.30^{\prime} \mathrm{W} ; 2589 \mathrm{~m}\right.$ water depth) to establish the age and nature of the basin province of the Falkland Plateau. Silicoflagellates are sparse to common and well preserved in the Quaternary and Pliocene sediment of Core 1 . Lower Oligocene through upper Eocene sediments from Sample 511-1-3,

Table 2. Relative abundances of silicoflagellates from the Pliocene to the Quaternary, Hole 511, Core 1.

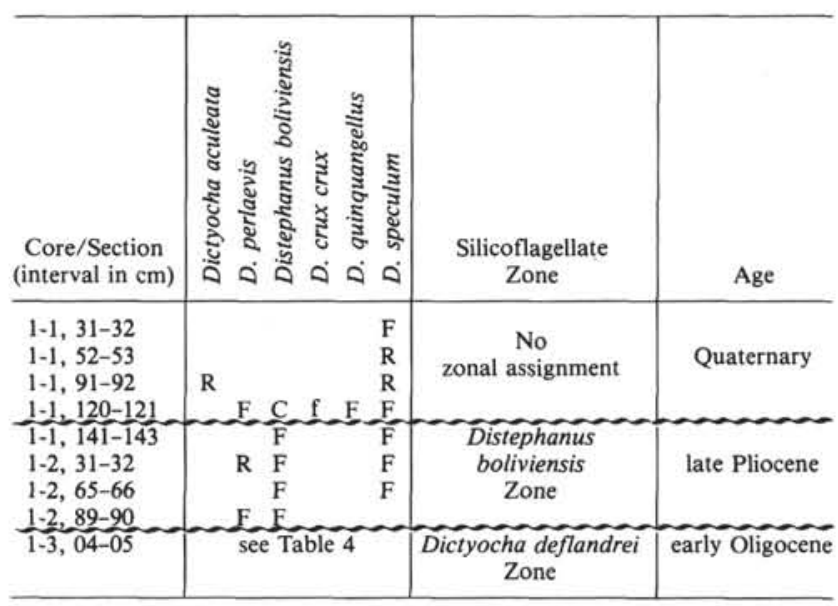

Note: $R$, rare (1-2 specimens/slide); $F$, few (several specimens/slide); $C$, common (at least 1 specimen/2-5 fields of view); a lower-case letter indicates that the specimen is considered reworked. 
Table 3. Abundances of all silicoflagellate skeletal morphotypes, Hole 511.

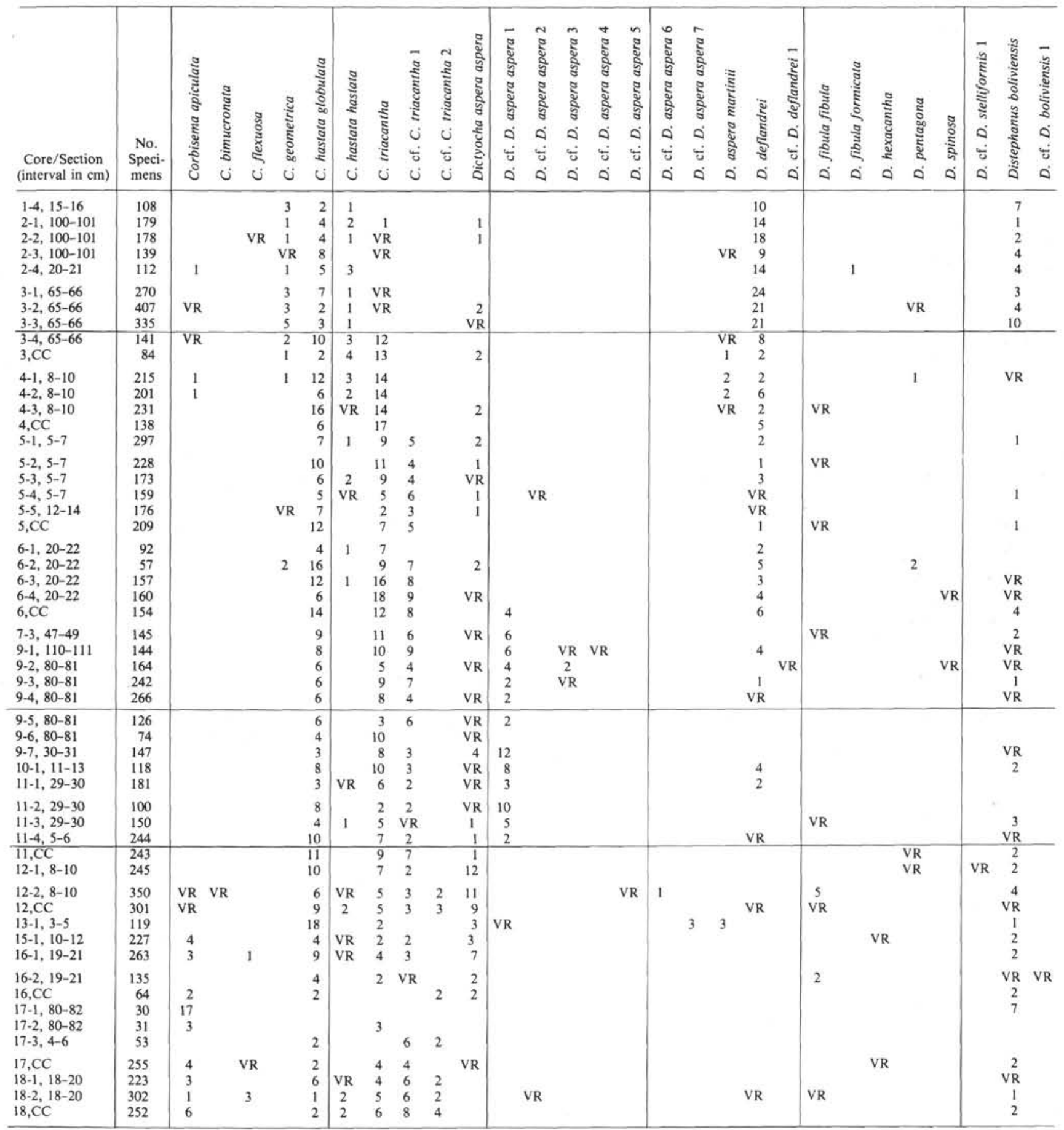

Note: Refer to Appendix for definitions or figures of each morphotype. Abundances are recorded as percentages. VR $=$ species abundance of $<1 \%$.

4-5 cm through Sample 511-20,CC contain common and well-preserved silicoflagellates; below Sample 51120, CC they are absent. Species diversity is low in the Quaternary and Pliocene sediments and high in the lower Oligocene-upper Eocene.

No age assignment is made for Samples 511-1-1, $31-32 \mathrm{~cm}$ through 511-1-1, 91-92 $\mathrm{cm}$ because of the presence of only rare Dictyocha aculeata and rare to few Distephanus speculum (Table 2). Ciesielski (this vol- ume) finds diatoms within this interval that are indicative of portions of several diatom zones correlative with the Brunhes and lower Matuyama chronozones.

Samples from the siliceous gravelly sand of Samples 511-1-1, 120-121 cm through 511-1-2, 89-90 cm contain a limited assemblage which includes Dictyocha perlaevis, Distephanus speculum, $D$. boliviensis, $D$. quinquangellus, and reworked (?) D. crux crux. Ciesielski (this volume) assigns this interval to the Nitzschia weaverii 
Table 3. (Continued).

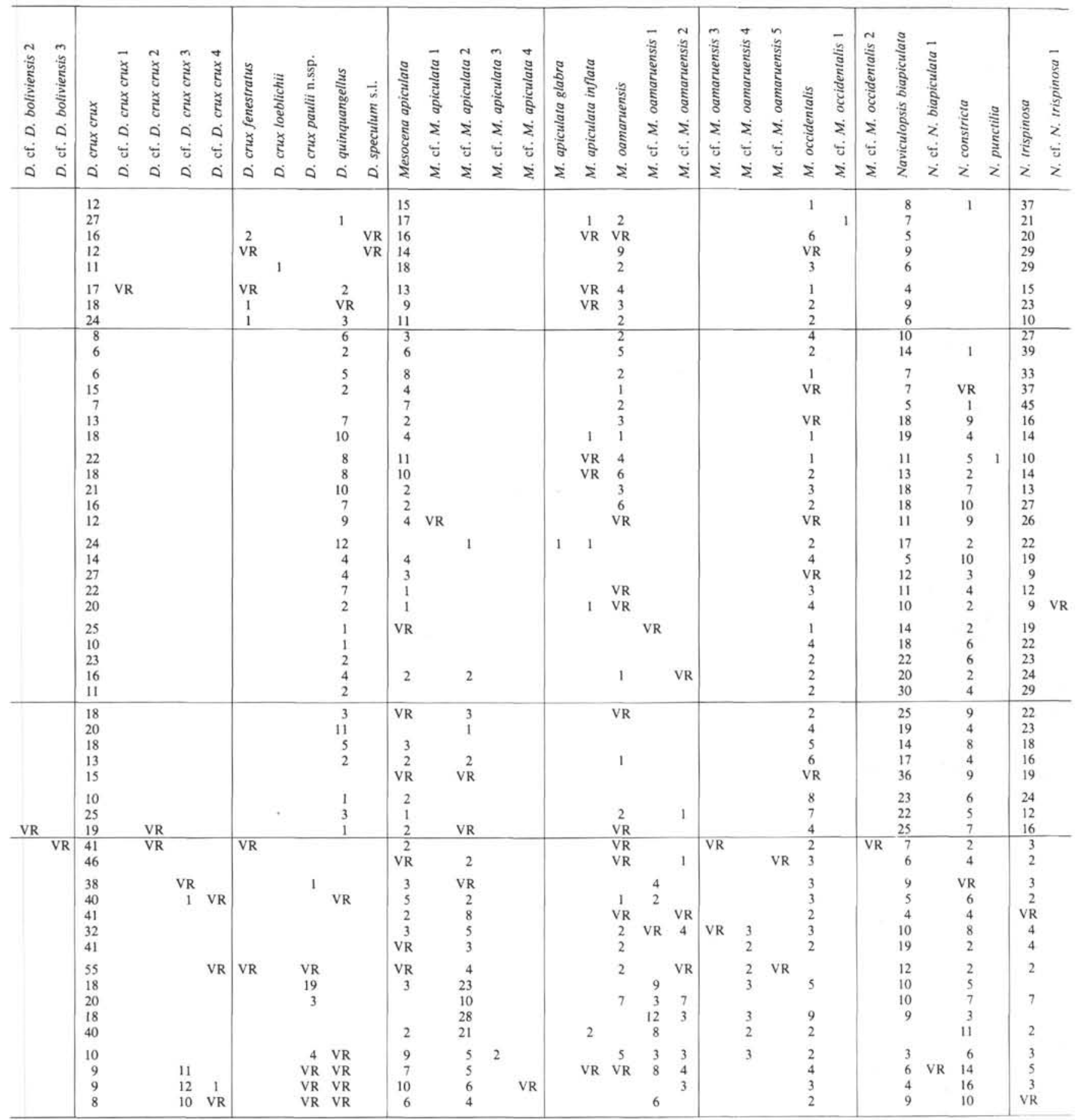

and $N$. interfrigidaria/Coscinodiscus vulnificus diatom zones, indicating a stratigraphic position within the upper to middle portion of the Gauss Chronozone of the upper Pliocene. The diatom stratigraphy indicates that the sparse silicoflagellate assemblage of this interval is correlative with the $D$. boliviensis Zone of Ciesielski (1975). A sharp lithologic boundary at 511-1-2, $144 \mathrm{~cm}$, separating siliceous gravelly sand above from diatom ooze below, is a disconformity between the upper Pliocene (Sample 511-1-2, 89-90 cm) and lower Oligocene (Sample 511-1-3, 4-5 cm).
Tables 3 and 4 list the silicoflagellate assemblage present in the continuous lower Oligocene through upper Eocene section present below this disconformity. Table 3 lists all skeletal morphotypes present as a percentage of the entire assemblage of each sample; descriptions of each morphotype are given in the Appendix. Those morphotypes from Table 3 which are considered to be valid species are included in the final species occurrence chart of Table 4. All other morphotypes are considered intraspecific variations of these species. 
Table 4. Silicoflagellate abundances, Hole 511. Intraspecific variations (Table 3 and Appendix) are combined.

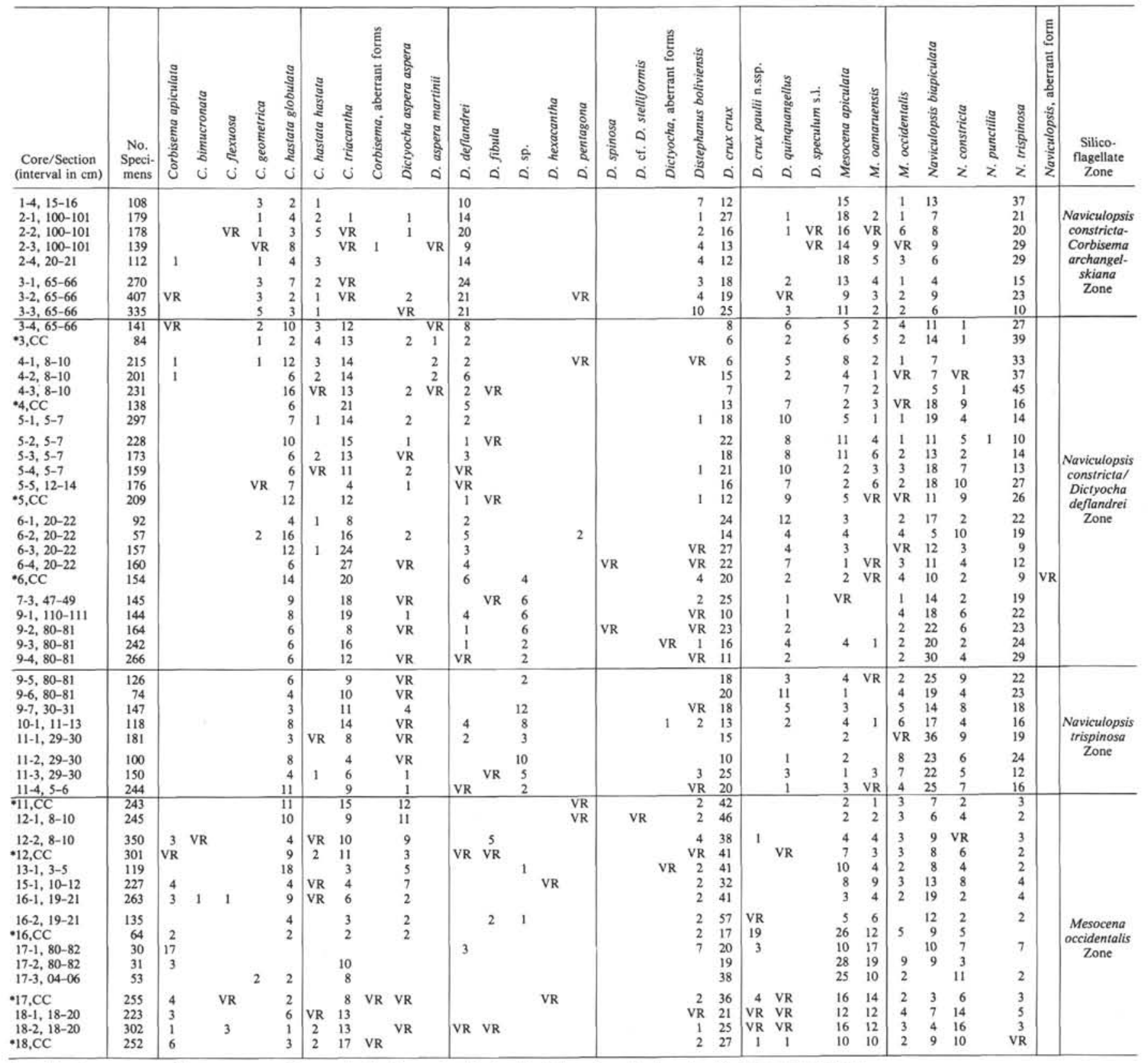

Note: Abundances are recorded as percentages. $\mathrm{VR}=$ species abundances of $<1 \%$. Asterisk indicates intervals where sieved fractions were examined.

Samples 511-1-3, 4-5 cm through 511-3-3, 65-66 cm are assigned to the Naviculopsis constricta-Corbisema archangelskiana Interval Zone of the lower Oligocene. The dominant silicoflagellate flora throughout this interval are $N$. trispinosa, $N$. biapiculata, Distephanus crux, and Dictyocha deflandrei. Other species commonly present in this zone include: $C$. apiculata, $C$. flexuosa, C. geometrica, D. aspera martinii, Distephanus crux loeblichii, and others.

Samples 511-3-4, 65-66 cm through 511-9-4, 80-81 $\mathrm{cm}$ contain the new $N$. constricta/Dictyocha deflandrei Zone. The well-preserved and diverse assemblage in these lower Oligocene sediments includes $N$. constricta, N. biapiculata, N. trispinosa, C. geometrica, C. apiculata, D. aspera martinii, Mesocena occidentalis, and others. Sediment recovery in Core 8 was poor and it was not sampled for study.

Samples 511-9,CC through 511-11-4, 5-6 cm are placed in the newly defined Naviculopsis trispinosa Zone of the lower Oligocene. This interval is characterized by abundant $N$. trispinosa. The first consistent occurrence of $D$. deflandrei marks the top of this zone; only few to rare $D$. deflandrei occur sporadically within the zone. Other species common in this interval include $N$. trispinosa, C. hastata globulata, C. triacantha, $M$. apiculata, M. occidentalis, $N$. biapiculata, and $N$. constricta.

Samples 511-11,CC through 511-18,CC are placed in the newly defined $M$. occidentalis Zone. The rich silicoflagellate assemblage of this upper Eocene-lowermost 


\begin{tabular}{|c|c|c|c|c|c|c|c|}
\hline के & Age & $\begin{array}{c}\text { Foraminifer } \\
\text { Zones } \\
\text { (Krasheninnikov) }\end{array}$ & $\begin{array}{c}\text { Calcareous } \\
\text { Nannofossil Zones } \\
\text { (Wise) }\end{array}$ & $\begin{array}{c}\text { Radiolarian } \\
\text { Zones } \\
\text { (Weaver) }\end{array}$ & $\begin{array}{c}\text { Silicoflagellate } \\
\text { Zones } \\
\text { (Shaw and Ciesielski) }\end{array}$ & $\begin{array}{c}\text { Diatom Zones } \\
\text { (Gombos and Ciesielski) }\end{array}$ & $\begin{array}{c}\text { New Zealand } \\
\text { Stages }\end{array}$ \\
\hline 1 & \multirow{13}{*}{$\begin{array}{c}\text { early } \\
\text { Oligocene }\end{array}$} & \multirow{12}{*}{$\begin{array}{l}\text { Globigerina } \\
\text { angiporoides Zone } \\
\text { and upper } \\
\text { G. brevis Zone } \\
(=\mathrm{P} 18-\mathrm{P} 20)\end{array}$} & E. huxleyi & Mixed assemblage & None & Several & \multirow{13}{*}{ Whaingaoran } \\
\hline \begin{tabular}{|l|}
2 \\
3
\end{tabular} & & & $\begin{array}{l}\text { Reticulofenestra } \\
\text { daviesii }\end{array}$ & $\begin{array}{c}\text { T. tuberosa } \\
\text { to early }\end{array}$ & $\begin{array}{c}\text { Naviculopsis constricta- } \\
\text { Corbisema }\end{array}$ & $\begin{array}{l}\text { Coscinodiscus } \\
\text { superbus Group }\end{array}$ & \\
\hline 4 & & & C. fenestrata & $\begin{array}{l}\text { D. ateuchus zonal } \\
\text { equivalent }\end{array}$ & archange/skiana & & \\
\hline 5 & & & \multirow{10}{*}{$\begin{array}{l}\text { Blackites } \\
\text { spinosus }\end{array}$} & \multirow{10}{*}{$\begin{array}{c}\text { Theocyrtis tuberosa } \\
\text { zonal equivalent }\end{array}$} & & \multirow{5}{*}{ Rhizosolenia gravida } & \\
\hline 6 & & & & & N. constricta/ & & \\
\hline \begin{tabular}{|l|}
7 \\
8
\end{tabular} & & & & & Dictyocha deflandrei & & \\
\hline 9 & & & & & & & \\
\hline 10 & & & & & \multirow[t]{2}{*}{ N. trispinosa } & & \\
\hline 11 & & & & & & Brightwellia spiralis & \\
\hline 12 & & & & & \multirow{7}{*}{$\begin{array}{c}\text { Mesocena } \\
\text { occidentalis }\end{array}$} & & \\
\hline 13 & & & & & & $\begin{array}{c}\text { Melosira } \\
\text { architecturalis }\end{array}$ & \\
\hline 14 & & & & & & & \\
\hline$\frac{15}{16}$ & & early Oligocene & & & & $\begin{array}{l}\text { Asterolampra } \\
\text { insignis }\end{array}$ & \\
\hline 17 & \multirow{3}{*}{$\begin{array}{c}\text { late } \\
\text { Eocene }\end{array}$} & late Eocene? & Barren & \multirow{3}{*}{$\begin{array}{c}\text { Thyrocyrtis bromia } \\
\text { zonal equivalent }\end{array}$} & & & \multirow{3}{*}{ Runangan } \\
\hline \begin{tabular}{|l|}
18 \\
19
\end{tabular} & & $\begin{array}{l}\text { Lower G. brevis Zone } \\
\text { and G. linaperta Zone }\end{array}$ & Reticulofenestra & & & $\begin{array}{c}\text { Rylandsia } \\
\text { inaequiradiata }\end{array}$ & \\
\hline 20 & & $(=\mathrm{P} 15-\mathrm{P} 16)$ & & & & 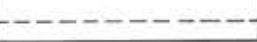 & \\
\hline
\end{tabular}

Figure 6. Correlation of Site 511 late Eocene-early Oligocene calcareous and siliceous microfossil zones and assemblages to each other and to New Zealand stages.

Oligocene interval includes common $C$. hastata globulata, C. triacantha, Distephanus boliviensis, D. crux crux, M. apiculata, M. oamaruensis, M. occidentalis, $N$. biapiculata, and $N$. constricta. $N$. trispinosa is present $(<10 \%)$ but is significantly less abundant than in younger strata of this site.

\section{Site 512 (Tables 5 and 6, Figure 5, Appendix; Ciesielski, this volume, Table 2)}

Site $512\left(49^{\circ} 52.19^{\prime} \mathrm{S}, 40^{\circ} 50.71^{\prime} \mathrm{W} ; 1846 \mathrm{~m}\right.$ water depth) lies on the northeastern part of the Maurice Ewing Bank at a location chosen to investigate further the depositional and erosional history of the Falkland Plateau. Hole 512 was continuously hydraulic piston cored to a sub-bottom depth of 77.9 meters, where coring was suspended because sediments became too indurated to penetrate. A second hole, $512 \mathrm{~A}$, was rotary cored after being washed to 80 meters. Only one core was recovered from Hole 512A, to a sub-bottom depth of 89.3 meters, before bad weather and sea conditions forced abandonment of the site.

Silicoflagellates are sparse throughout the Quaternary to upper middle Miocene sediments of Cores 1 through 5 and common to abundant in the middle Eocene sediments of Cores 6 to 19. Preservation is poor and diversity low in Section 512-1-1. Upper to upper middle Miocene sediments examined between Samples 512-1-1, 100-101 cm and 512-5, CC contain an excellently preserved but low-diversity assemblage of silicoflagellates. Cores 6 through 19 contain an assemblage of middle Eocene silicoflagellates that is characterized by high diversity, great abundance, and excellent preservation.

Six samples from the thin Quaternary-Pliocene sequence of Section 512-1-1 were examined for their silicoflagellate content. Five of the samples (512-1-1, 13-14 cm; 512-1-11, 24-25 cm, 512-1-1, 34-35 cm, 512-1-1, $64-65 \mathrm{~cm}$, and $512-1-1,80-81 \mathrm{~cm}$ ) contain a sparse assemblage of silicoflagellates consisting of rare to few Distephanus speculum and rare Dictyocha aculeata, D. perlaevis, Distephanus polyactis, $D$. boliviensis and $D$. quinquangellus. No zonal designation is given to this interval, which Ciesielski (this volume) correlates to the Matuyama Chronozone and middle portion of the Gauss Chronozone. Sample 512-1-1, 88-89 cm contains a few D. boliviensis, Mesocena diodon, and Dictyocha perlaevis. Ciesielski (this volume) assigns this sample to the Nitzschia angulata Diatom Zone of the paleomagnetic Gilbert Chronozone, indicating that Mesocena diodon is reworked.

Sample 512-1-1, 100-101 cm contains $M$. circulus and a diatom and radiolarian assemblage indicative of the upper Miocene. Thus, a disconformity exists between this sample and the lower Pliocene of Sample 512-1-1, $88-89 \mathrm{~cm}$. The disconformity between 89 and $100 \mathrm{~cm}$ of Section 1 probably coincides with a change in lithology at $93 \mathrm{~cm}$ from diatomaceous quartz sand above to diatomaceous ooze below.

Samples 512-1-1, 100-101 cm through 512-5,CC are assigned to the $M$. circulus Zone. The paleomagnetic polarity record of this sequence is presented by Ledbetter (this volume).

The lithologic boundary between Lithologic Subunits $2 \mathrm{~B}$ and $2 \mathrm{C}$ corresponds to a disconformity separating the upper middle Miocene of Core 5 from the middle Eocene of Core 6. Samples from 512-6-1, 78-80 cm to the base to Hole 512 and all of Hole 512A are assigned to the new Dictyocha grandis Zone. The silicoflagellate assemblage of this middle Eocene siliceous nannofossil ooze is characterized by the presence of $D$. grandis n.sp.

The $D$. grandis Zone is subdivided into three subzones; the $D$. stelliformis Subzone, the $D$. stelliformis$M$. apiculata Interval Subzone, and the $M$. apiculata Subzone. Samples 512-6-1, 78-80 cm through 512-13-2, 43-45 cm contain the $M$. apiculata Subzone. The remainder of Core 13 through Sample 512-16-2, $15-17 \mathrm{~cm}$ contains a silicoflagellate flora characteristic of the $D$. stelliformis-M. apiculata Interval Subzone, which lies between the last occurrence of $D$. stelliformis n.sp. and 
Table 5. Abundances of all silicoflagellate skeletal morphotypes, Site 512.

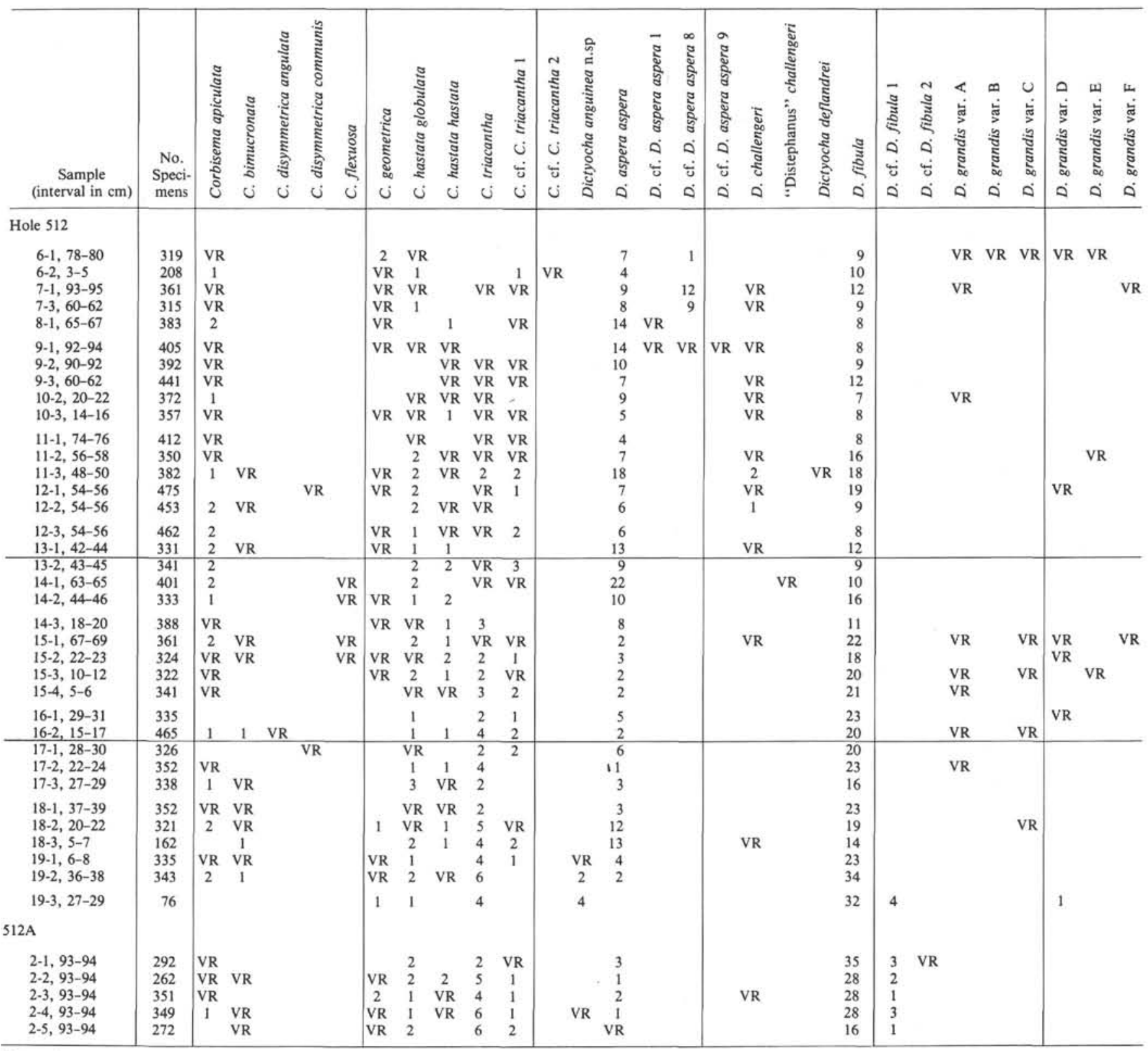

Note: Abundances are recorded as percentages. VR $=$ species abundance of $<1 \%$.

the first occurrence of $M$. apiculata. The D. stelliformis Subzone is present in Cores 17 through 19, and in Hole 512A. The last occurrence of $D$. stelliformis n.sp. in Sample $512-17-1,28-30 \mathrm{~cm}$ marks the top of the latter subzone.

Ledbetter (this volume) has determined the polarity reversal pattern for the middle Eocene section recovered from Hole 512 and correlated the results to the paleomagnetic time scale. Based on the foraminiferal biostratigraphy derived from these sediments (Krasheninnikov and Basov, this volume), the paleomagnetic polarity of the sediment from Cores 6 through 19 was compared with the magnetic anomaly reversal pattern for Anomalies 16-20 of LaBrecque et al. (1977) and Ness et al. (1980). On the basis of Ledbetter's results, it can be seen that the section of Hole 512 from Cores 6 through
19 correlates with the interval from Magnetic Anomaly 18 to slightly younger than Magnetic Anomaly 20, spanning from $43.7 \mathrm{Ma}$ to $40.9 \mathrm{Ma}$. (Fig. 5).

\section{Site 513 (Tables 7 and 8, Figures 4 and 7)}

Site $513\left(47^{\circ} 34.99^{\prime} \mathrm{S}, 24^{\circ} 38.40^{\prime} \mathrm{W} ; 4383 \mathrm{~m}\right.$ water depth) is located on the lower western flank of the MidAtlantic Ridge, near the southeastern margin of the Argentine Basin. Two holes were rotary drilled and continuously cored to basement at a sub-bottom depth of 387 meters. The first hole at Site 513 was drilled to a depth of 1040 meters sub-bottom; however, sediment recovery below 56.5 meters was limited to Core 9 (75.5$85.0 \mathrm{~m}$ ). The second hole, 513A, filled in the drilling gap of the first hole $(56.5$ to $75.5 \mathrm{~m})$ and then was continuously drilled to basement. 
Table 5. (Continued).

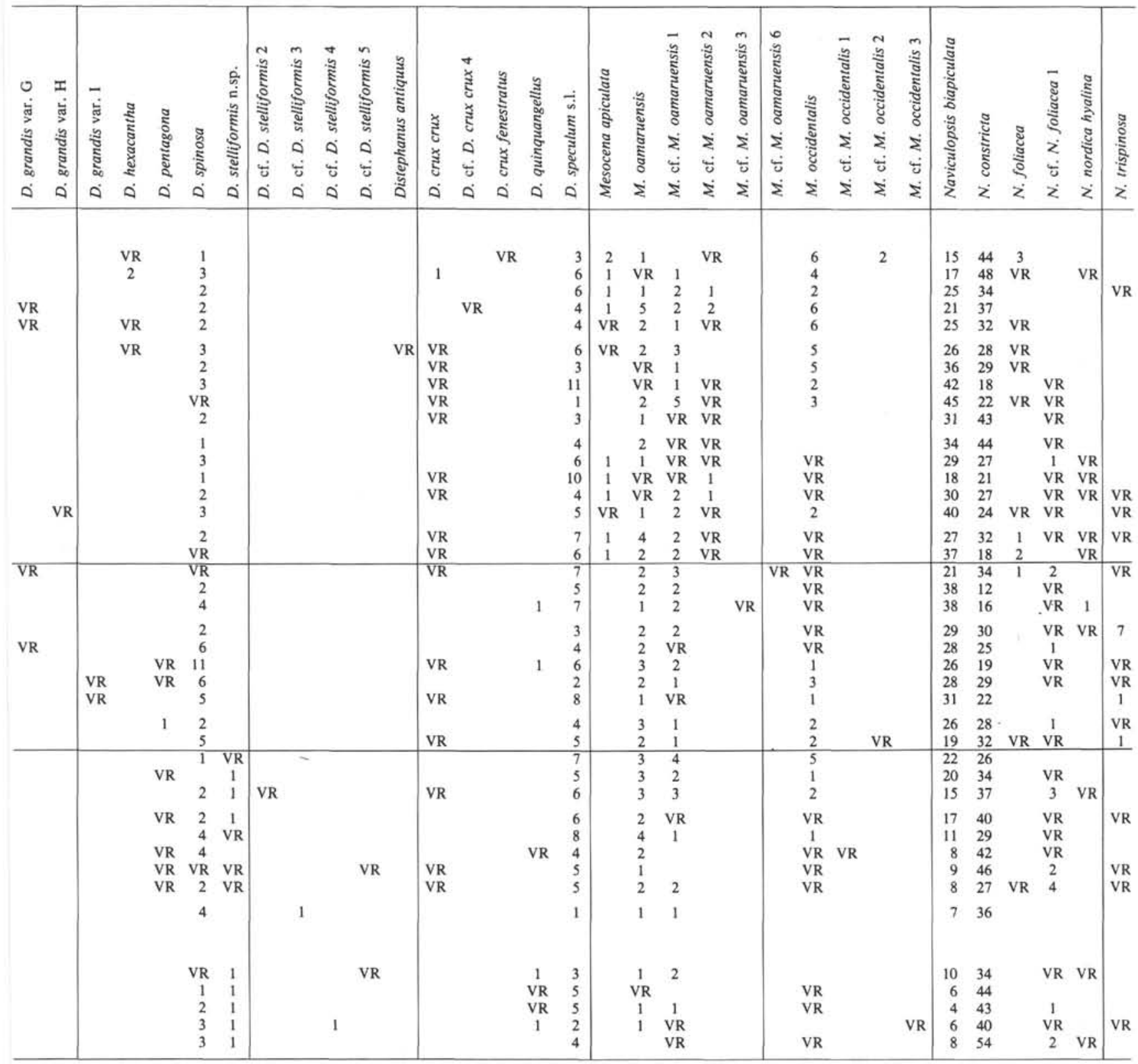

Only a few sporadic occurrences of silicoflagellates are found in Quaternary and lower to upper Pliocene sediments between $513-1-1,123-125 \mathrm{~cm}$ and 513A-1-3, $40-42 \mathrm{~cm}$. No zonal assignment was made for this interval because of the low species diversity and abundance.

Silicoflagellates are generally common and consistently present in the upper Miocene through lower Pliocene between Samples 513A-2-1, 5-7 and 513A-11-7, $46-48 \mathrm{~cm}$. The Mesocena diodon zone is identified between 513-9-6, 6-8 $\mathrm{cm}$ and 513A-7-2, 57-59 $\mathrm{cm}$ and the M. circulus $/ M$. diodon Zone occurs between $513 \mathrm{~A}-7-4$, $70-72 \mathrm{~cm}$ and $513 \mathrm{~A}-11-2,120-122 \mathrm{~cm}$. Samples 513A$11-3,142-144$ through 513A-12-1, 9-11 cm contain mostly reworked silicoflagellates and a few $M$. circulus. $M$. diodon is absent in this latter interval, but this may be because of the poor preservation of the interval, which may represent either the $M$. circulus Zone or the $M$. diodon/M. circulus Zone.

Diatoms and other microfossil groups indicate the presence of a disconformity between 513A-12-1, 9-11 $\mathrm{cm}$ and 513A-12-1, 123-125 cm, separating upper Miocene from lower Miocene sediment (Gombos and Ciesielski, and others, this volume). Core 12 through Core 33 contain a succession of lower Oligocene through lower Miocene sediments, apparently free of major disconformities.

Samples 513A-12-3, 128-130 through 513-14-6, 46-48 $\mathrm{cm}$ are assigned to the newly defined Naviculopsis biapiculata Zone. The age of this zone is early Miocene, according to the planktonic foraminifer studies of Basov and Krasheninnikov (this volume) and the base of the zone approximates the Oligocene/Miocene boundary. 
Table 6. Silicoflagellate abundances, Site 512. Intraspecific variations (Table 5 and Appendix) are combined.

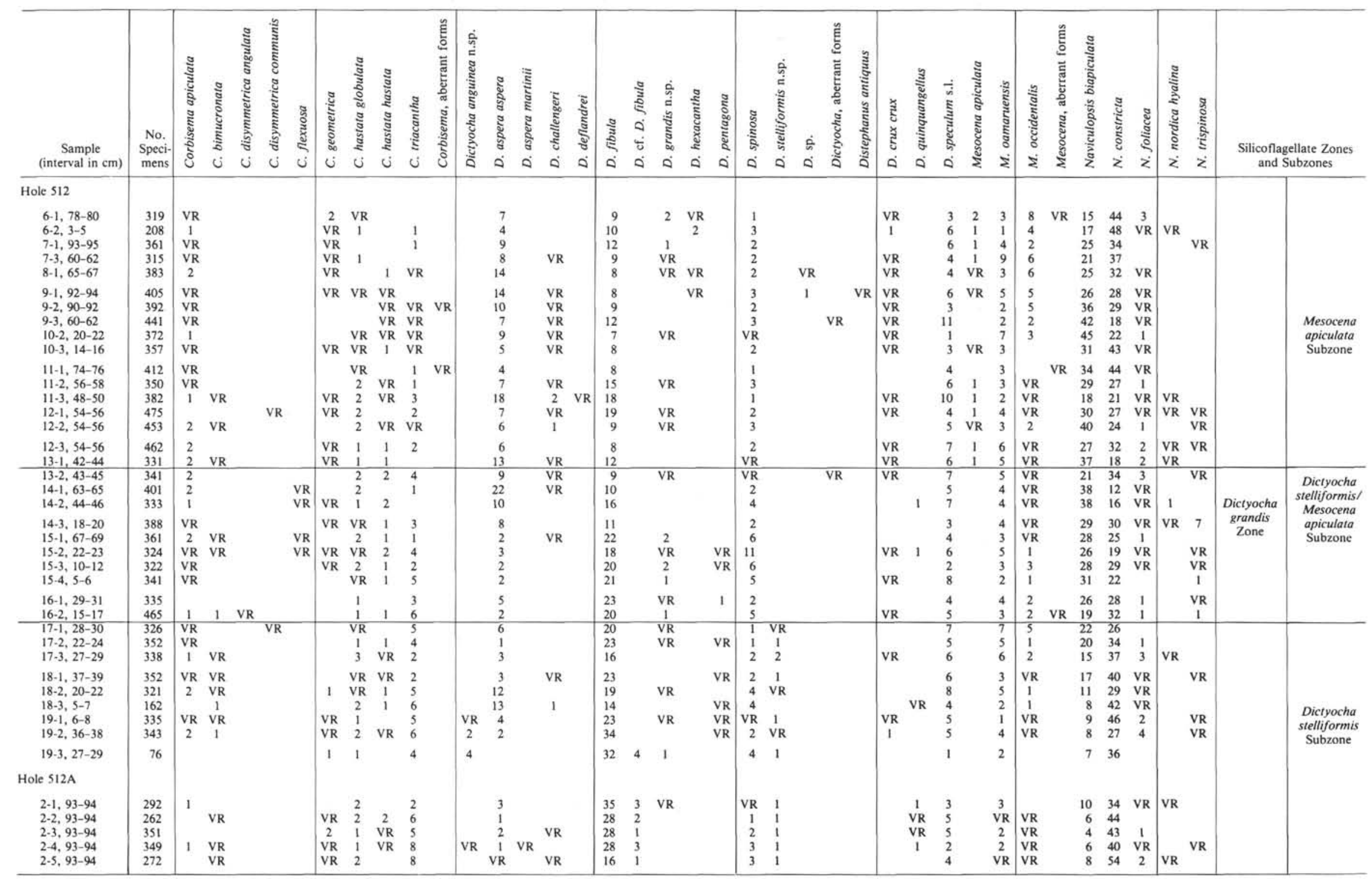

Note: Abundances are recorded as percentages. $\mathrm{VR}=$ species abundances of $<1 \%$. 


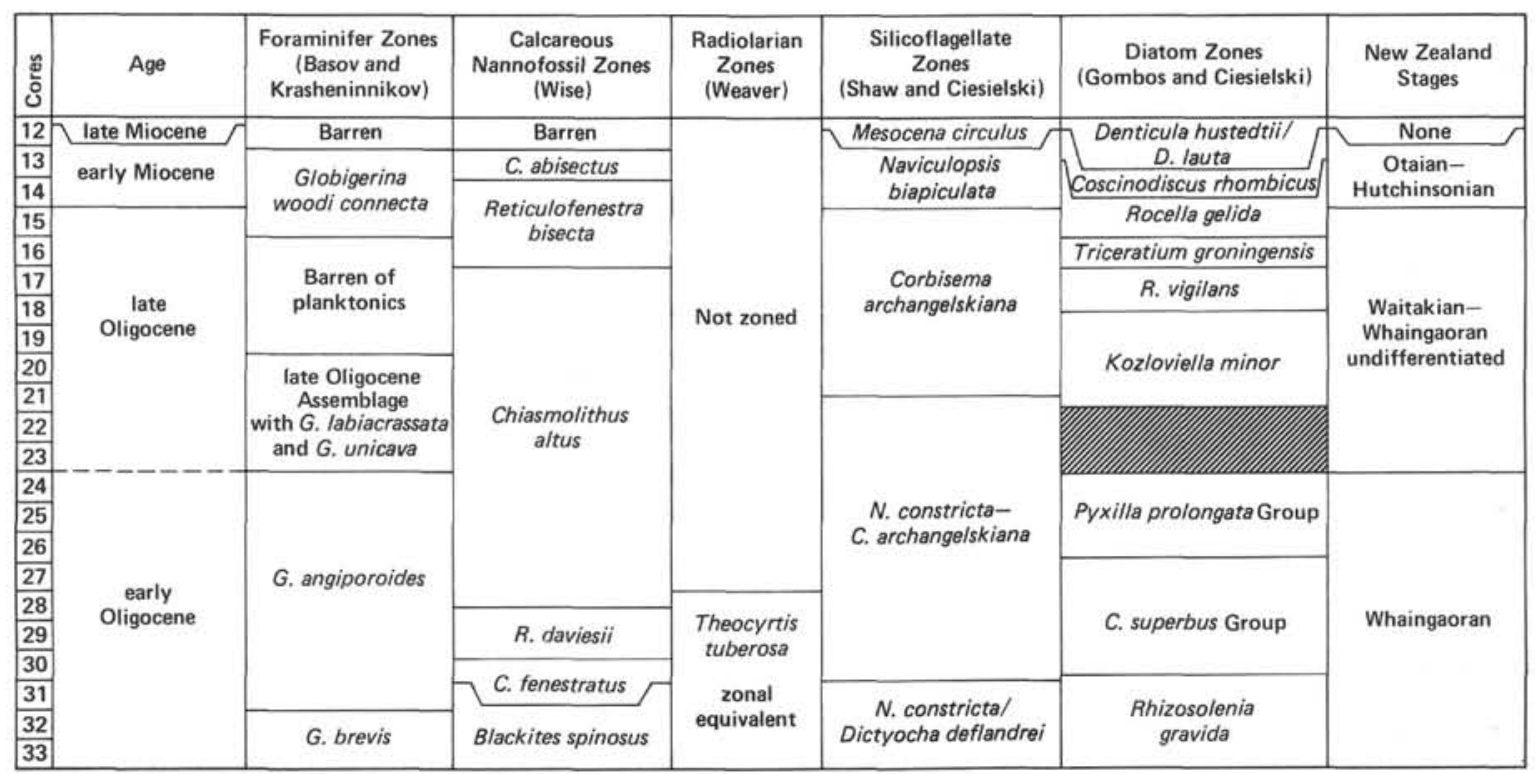

Figure 7. Correlation of Site 513 early Oligocene-early Miocene calcareous and siliceous microfossil zones and assemblages to each other and to New Zealand stages.

Silicoflagellates are rare and poorly preserved in Core 513A-12; however, they are common and well preserved in Cores 513A-13 and 513A-14. Diversity within the $N$. biapiculata Zone is low; Distephanus crux crux, D. boliviensis hemisphaericus, and Naviculopsis biapiculata dominate the assemblage.

Samples 513A-15-3, 119-121 cm through 513-21-1, $70-72 \mathrm{~cm}$ are placed in the newly established Corbisema archangelskiana Zone of the upper Oligocene. Silicoflagellates from this interval are moderately diverse and well preserved. The most abundant species occurring within this interval include $C$. archangelskiana, Distephanus boliviensis hemisphaericus, D. crux crux, D. quinquangellus, M. apiculata, and N. biapiculata. N. trispinosa has its last occurrence in Sample 513A-16-3, 23-25 $\mathrm{cm}$ and the diatom Rocella gelida, formerly thought to be a silicoflagellate (Gombos and Ciesielski, this volume), has its uppermost Oligocene acme in Core 513A15.

Samples 513A-22-1, 14-16 cm through 513A-30-2, 29-31 cm are assigned to the $N$. constricta-C. archangelskiana Interval Zone which brackets the lower/upper Oligocene boundary. The remainder of the hole, from $513 \mathrm{~A}-31-2,21-23 \mathrm{~cm}$ through $513 \mathrm{~A}-33-7,55-57 \mathrm{~cm}$, is placed in the newly defined Naviculopsis constricta/ Dictyocha deflandrei Zone. The detailed assemblage characteristics of the $N$. constricta-C. archangelskiana Interval Zone and $N$. constricta/D. deflandrei Zone are presented in the preceding discussion of zonations.

\section{Site 514 (Ciesielski, this volume, Table 4)}

Site $514\left(46^{\circ} 02.77^{\prime} \mathrm{S}, 26^{\circ} 51.30^{\prime} \mathrm{W} ; 4318 \mathrm{~m}\right.$ water depth) is east of the Argentine Basin on the lower west flank of the Mid-Atlantic Ridge. A continuous Pliocene-Quaternary sequence of diatomaceous clays and muddy diatomaceous oozes was hydraulic piston cored to a sub-bottom depth of 150.8 meters. Site 514 is about $400 \mathrm{~km}$ north of the present-day position of the Polar
Front and about $240 \mathrm{~km}$ north of Site 513. A major objective at both sites was to determine the late Cenozoic history of the Polar Front.

Hole 514 has a low-diversity assemblage of silicoflagellates which has been tabulated by Ciesielski with the diatom assemblage of this hole (Ciesielski, this volume). Silicoflagellates are sparse throughout most of Cores 110 and sparse to common throughout most of Cores 1133 , except for a few abundant occurrences.

Distephanus speculum s.l. is the only species consistently present in Cores 514-1-10. A few Dictyocha aculeata occur in Sample 514-1,CC, rare to few Mesocena quadrangula occur in samples between Sample 514-4-1, $123-125 \mathrm{~cm}$ and 514-4,CC, and common Distephanus polyactis are found between Sample 514-6-1, 77-79 cm through $514-6-3,77-79 \mathrm{~cm}$.

The occurrences of Dictyocha aculeata, M. quadrangula and Distephanus polyactis are consistent with the paleomagnetic record Salloway and Bloemendal (this volume) have identified for Cores 514-1-10. Dictyocha aculeata occurs only in the Brunhes Chronozone of Core 1. Ciesielski has also noted a restricted occurrence of this species in upper Brunhes Chronozone sediments of the Falkland Plateau. The range of $M$. quadrangula brackets a normal subchron within Core 514-4. At lower latitudes this species is a reliable stratigraphic marker with a restricted stratigraphic range, occurring in upper Matuyama Chronozone sediments of several ocean basins. Burckle (1977) noted that the range of M. quadrangula (1.3-0.78 Ma) brackets the Jaramillo Subchron $(0.98-0.91 \mathrm{Ma})$ of the Matuyama. Thus, the range of $M$. quadrangula agrees with the designation of the short normal-polarity interval within Core $514-4$ as the Jaramillo Subchron of the Matuyama Chron. Distephanus polyactis is present within and slightly below a short normal-polarity interval in lower Core 514-5 and upper Core 514-6. Ciesielski (1975, and unpublished data) noted the occurrence of $D$. polyactis within the Olduvai 
Subchronozone and lower Matuyama Chronozone, agreeing with a designation of the normal-polarity zone within Cores 514-5 and 514-6 as the Olduvai Subchron.

The interval from Sample 514-11-1, 100-102 cm to the base of the hole is identified as the Distephanus boliviensis Zone of Ciesielski (1975). Few to common $D$. boliviensis occur throughout the zone. More sporadically present are $D$. boliviensis (cannopilean) and $D$. quinquangellus; both occur more consistently and are more common near the Gauss/Matuyama Chronozone boundary and in Gilbert Chronozone sediments below the Cochiti Subchronozone. D. crux occurs only below the Cochiti Subchronozone. A few M. elliptica are present in Cores 26 and 27. Dictyocha species occur sporadically above the upper Gilbert-lower Gauss disconformity between Cores 514-26 and 514-27 but are more consistently present below the disconformity.

Only one significant occurrence of reworked silicoflagellates occurs in Hole 514. Rare $N$. biapiculata and few $M$. apiculata occur in two samples, 514-19-1, 20-22 $\mathrm{cm}$ and $514-19-1,72-74 \mathrm{~cm}$. In both samples these reworked silicoflagellates are accompanied by common reworked diatoms from the late Oligocene and earliest Miocene (Ciesielski, this volume). These common reworked siliceous microfossils occur within the upper normal paleomagnetic polarity zone of the Gauss Chronozone, a portion of the Hole 514 sequence with an extremely high sediment accumulation rate. Deposition of the reworked late Oligocene-earliest Miocene siliceous microfossils in Core 19 immediately preceded a major northward migration of the Polar Front over Site 514 (Ciesielski and Weaver, this volume).

Dictyocha species are common in all, or portions of Cores 2, 28, 29, 31, and 33-35. In all cases, common occurrences of Dictyocha species are accompanied by a radiolarian biofacies indicative of a Polar Front position south of the site at the time of deposition (Ciesielski and Weaver, this volume).

\section{SYSTEMATIC PALEONTOLOGY \\ Order SIPHONOTESTALES Lemmermann, 1901 Genus CANNOPILUS Haeckel, 1887 \\ Cannopilus sphaericus Gemeinhardt, 1931b (Plate 18, Figs. 1-5)}

Cannopilus sphaericus Gemeinhardt, 1931b, p. 104, pl. 10, figs. 3-4. Remarks. This species was recorded in only one sample, $513 \mathrm{~A}-26$, $\mathrm{CC}$, from the lower Oligocene portion of the Dictyocha deflandrei Zone.

Genus CORBISEMA Hanna, 1928, emend. Frenguelli, 1940

The generic concept and application of Corbisema is loose. The genus was originally defined by Hanna (1928) as having a triangular basal ring. Frenguelli (1940) emended the definition of Corbisema to consider the position of the accessory spines. According to Frenguelli, representatives of the genus have accessory spines that are directly connected to the lateral bars instead of the basal ring, distinguishing it from the genus Dictyocha.

The position of the accessory spines is the single most important characteristic of the genus; however, some specimens do not possess accessory spines but otherwise closely resemble Corbisema species. As can be seen in Plate 1, Figure 2, in a specimen which in every other way is a Corbisema species, accessory spines may even be attached to the basal ring. In cases such as these, affiliation to either Dictyocha or Corbisema is made on basis of other similarities to species of the two genera (Busen and Wise, 1977). As other workers have found out, strict adherence to the generic definitions is not practical because of the skeletal variability of the silicoflagellates.

\section{Corbisema apiculata (Lemmermann) Hanna, 1931}

(Plate 1, Figs. 1-3)

Dictyocha triacantha var. apiculata Lemmermann, 1901, p. 259, pl. 10, figs. 19-20 (fide Loeblich et al., 1968, p. 117). Corbisema apiculata (Lemmermann), Hanna, 1931, p. 198, pl. D, fig. 2 (fide Loeblich et al., 1968, p. 30). D. triacantha var. apiculata f. apiculata Glezer, 1966, p. 245, pl. 6, fig. 5.

Remarks. This species is recognized by its mildly globular triangular shape with short to moderately long spines at the apices. It bears a strong resemblance to Corbisema hastata globulata but can be distinguished by its equilaterally triangular shape. Accessory spines are generally not present, but in some specimens (see Plate 1, Fig. 2) small accessory spines are attached to the basal ring at the juncture with the lateral rods. C. apiculata is sporadically present in small quantities in Hole 511; it is absent in Cores 5 through 11. At Site 512, it is consistently present but rare throughout the middle Eocene. In Hole 513A it occurs sparsely in the lower Oligocene.

Corbisema archangelskiana (Schulz) Frenguelli, 1940 (Plate 19, Figs. 1-4, 6; Plate 20, Fig. 1)

Dictyocha triacantha var. archangelskiana Schulz, 1928, pp. 250, 251, fig. 33a-c; p. 281, fig. 77-78(?). Gemeinhardt, 1930, pp. 45, 46, fig. 37a, b(?). Corbisema archangelskiana Frenguelli, 1940, fig. 12a.

Remarks. In Leg 71 samples the range of Corbisema archangelskiana is restricted to the upper Oligocene of Hole 513A. This large species exhibits considerable morphologic variation of the apical and basal apparatus. All specimens have equilateral indented sides, bluntly rounded apices, and no accessory or basal spines. The apical bars may be equal (Plate 20, Fig. 1) or unequal in length (Plate 19, Figs. 1-4, 6), relatively straight (Plate 19, Figs. 1, 3-4, 6; Plate 20, Fig. 1) or irregular (Plate 19, Fig. 2), and may connect with the mid-point of each side of the basal apparatus (Plate 19, Figs. 4 and 6; Plate 20, Fig. 1) or closer to one apex than the other of the basal apparatus (Plate 19, Figs, 1-3). The degree of indentation and geometry of the sides of the basal apparatus is highly variable: in some specimens portions of it exhibit an irregular, wavy appearance (Plate 19, Figs. 1-2). Aberrant skeletal formation, particularly of the basal apparatus, was frequently seen (Plate 19, Figs. 2 and 4). Thickenings occasionally occur on the abapical side of the basal apparatus where the lateral rods connect (Plate 19, Fig. 4). The stratigraphic ranges of all skeletal morphotypes were recorded and no range differences were noted; all morphotypes are, therefore, considered intraspecific variations of $C$. archangelskiana.

\section{Corbisema bimucronata Deflandre, 1950}

(Plate 1, Figs. 4-6)

Corbisema bimucronata Deflandre, 1950, p. 63, figs. 174-177 (fide Loeblich et al., 1968, p. 75). Dictyocha bimucronata (Deflandre) Tsumura, 1963, p. 50, pl. 9, fig. 6 (fide Loeblich et al., 1968, p. 33). C. bimucronata Ling, 1972, p. 153, pl. 24, fig. 1.

Remarks. This species has a triangular basal ring with sharply truncated apices. The specimens seen here have no short spines at the edge of the truncated margins. Corbisema bimucronata is present sporadically in rare quantities at Site 512 . In Hole 511, a few specimens of C. bimucronata are present in Cores 12 and 16 .

\section{Corbisema disymmetrica angulata Bukry, 1976a}

(Plate 1, Fig. 8)

Corbisema disymmetrica angulata Bukry, 1976a, p. 891, pl. 1, figs. 5-9. C. cuspis Busen and Wise, 1977, p. 711, pl. 1, figs. 4-6.

Remarks. A sole specimen of this boat-shaped species is present in Core 16 at Hole 512. The basal ring shows no constriction at the juncture of the basal ring and the apical bar. Bukry (1976a) and Busen and Wise (1977) described this species from the upper Paleocene through lower Eocene at Hole 327A. The presence of one specimen in Hole 512 could indicate an extended range for Corbisema disymmetrica angulata up into, at least, the middle Eocene at Hole 512, but could also in- 
Table 7. Relative abundance of silicoflagellates from the Neogene of Holes 513 and 513A.

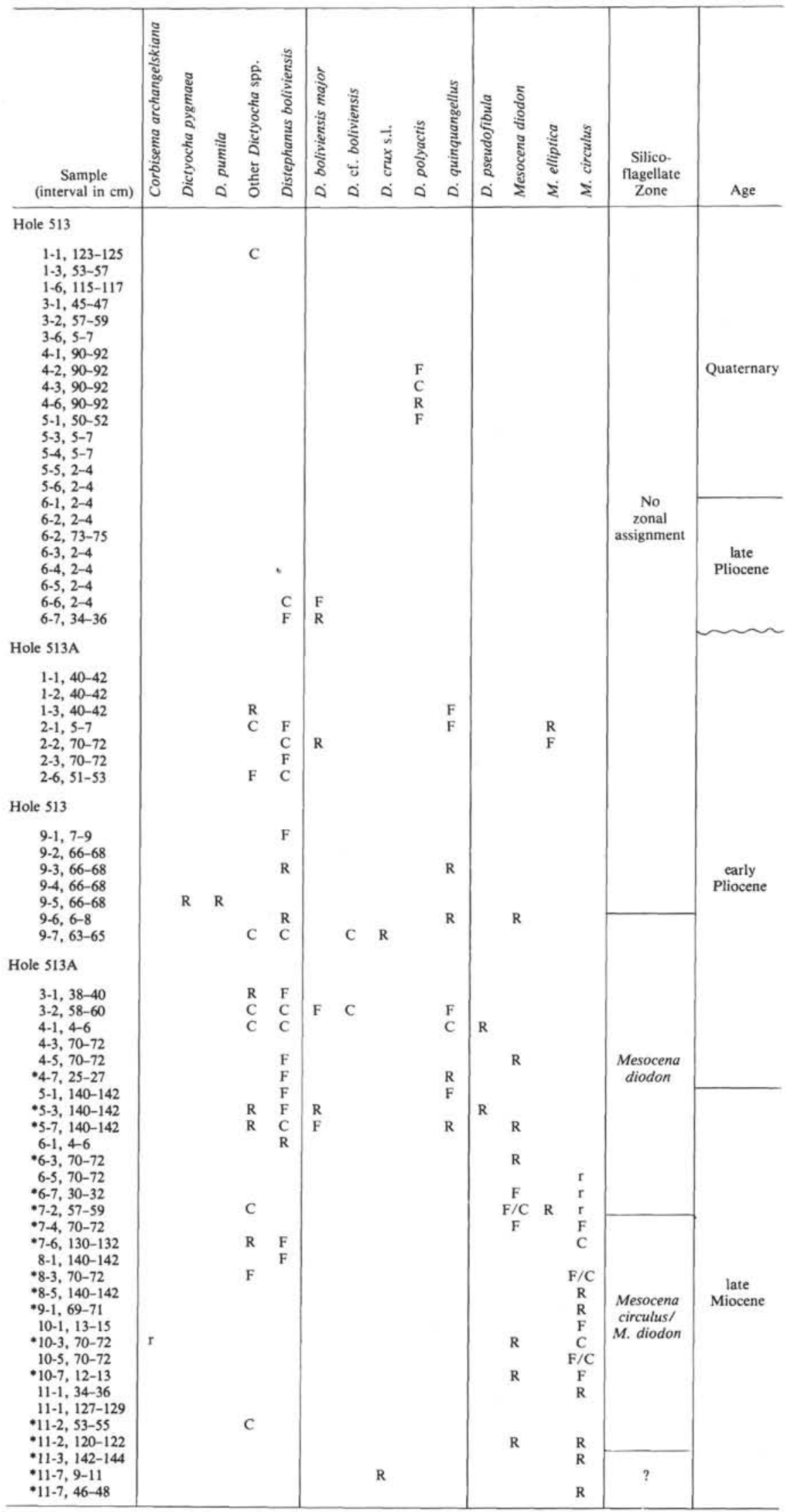

Note: $R$, rare (1-2 specimens/slide); F, few (several specimens/slide); C, common (at least 1 specimen/2-5 fields of view). Asterisk indicates intervals where sieved fractions were examined. 
Table 8. Silicoflagellate abundances, Hole 513A.

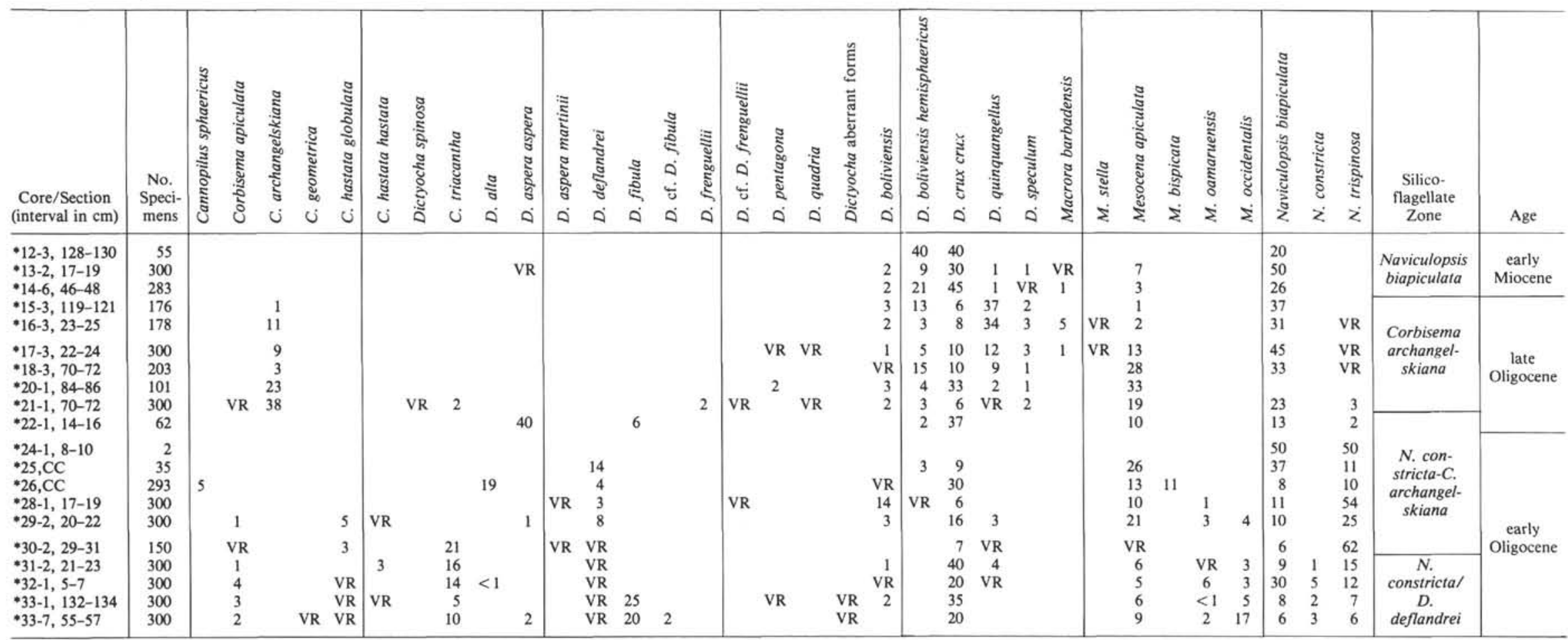

Note: Abundances are recorded as percentages. $V R=$ species abundance of $<1 \%$. Asterisk indicates intervals where sieved fractions were examined. 
dicate reworking of Paleocene material into the middle Eocene. Until the range of Corbisema disymmetrica angulata has been properly delineated, it will not be possible to explain its presence in Hole 512 with certainty.

\section{Corbisema disymmetrica communis Bukry, 1976b}

(Plate 2, Fig. 1)

Corbisema disymmetrica communis Bukry, 1976a, p. 891, pl.1, figs. 1-4. Dictyocha navicula (Ehrenberg) Schulz, 1928 (in part), p. 243, fig. 16a; Glezer, 1966 (in part), vol. 7, pp. 251-252, pl. 9, figs. 4-5; Tsumura, 1963, pp. 43-44, pl. 7, fig. 4 (fide Busen and Wise, 1977, p. 712). C. navicula navicula (Ehrenberg) Busen and Wise, 1977 , p. 712, pl. 2, figs. 7-9.

Remarks. This species occurs rarely, in two samples from Hole 512 (Cores 12 and 17, respectively), and is recognized by its oval to elliptical basal ring, bisected by a narrow apical bar. Sustaining spines were not observed in either specimen. The species was restricted to the Paleocene of nearby Falkland Plateau Hole 327 (Busen and Wise, 1977). Its presence in the middle Eocene of Hole 512 may, therefore, be due to reworking.

\section{Corbisema flexuosa (Stradner) Perch-Nielsen, 1975}

(Plate 1, Figs. 7, 9)

Corbisema triacantha var. flexuosa Stradner, 1961, p. 89, pl. 1, figs. 1-8, fig. 1C (fide Loeblich et al., 1968, p. 76-77). C. flexuosa (Stradner) Perch-Nielsen, 1975, p. 685, pl. 3, fig. 10.

Remarks. This small species is characterized by a distinctly indented equal-sided body and moderately long spines at the body-ring apices. The specimens seen at Sites 511 and 512 do not possess a broad triangular plate. We suggest that the distinctive outline of the basal ring is sufficient to distinguish the species, and that it should not be subdivided according to whether the specimen possesses a broad hyaline plate or a simple juncture of three lateral rods.

Corbisema flexuosa is present only rarely at Sites 511 and 512: in Cores 511-2, and 511-16-18, and in Cores 512-14-15.

\section{Corbisema geometrica Hanna, 1928}

(Plate 1, Figs. 10-12)

Corbisema geometrica Hanna, 1928, no. 4, p. 261, pl. 41, figs. 1, 2 (fide Loeblich et al., 1968, p. 75). Glezer, 1966, pp. 271-272, pl.9, fig. 7.

Remarks. This species is recognized by its trilobate to almost circular outline. Most specimens possess three small apical spines. Generally, the specimens have three apical bars with a simple juncture (Plate 1, Figs. 10,12), but specimens with a triangular apical plate are also present (Plate 1, Fig. 11).

In Hole 511, rare to few Corbisema geometrica are present consistently in Cores 511-1 through 3, and sporadically below that. C. geometrica is present sporadically throughout Holes 512 and $512 \mathrm{~A}$ and has a single rare occurrence at the base of Hole 513A.

\section{Corbisema hastata globulata (Lemmermann) Bukry, 1976a} (Plate 1, Figs. 13-16)

Dictyocha triacantha var. hastata Lemmermann, Glezer, 1966 (in part), p. 248, pl. 7, fig. 1 (fide Bukry, 1976b, p. 892). Corbisema hastata (Lemmermann) Ling, 1972, p. 155, pl. 24, fig. 5. C. hastata globulata (Lemmermann) Bukry, 1976a, p. 892, pl. 4, figs. 1-8.

Remarks. The specimens identified from Sites 511 and 512 support, in part, subdivision of the Corbisema hastata (Lemmermann) group. C. hastata globulata is recognized by its lobate outline and short spines at the basal ring apices. It is distinguished from $C$. apiculata by its isosceles basal outline and from $C$. hastata hastata by the latter's generally smaller size and straighter short side of the basal ring. $C$. hastata globulata is commonly present, though few in number, throughout Hole 511. At Site 512, it is present in smaller numbers. In Hole 513A, few to sparse specimens occur in the lower Oligocene between Samples 513A-29-2, 20-22 cm and 513A-33-7, 55-57 cm.

\section{Corbisema hastata hastata (Lemmermann) Bukry, 1975b}

$$
\text { (Plate 2, Figs. 2-4) }
$$

Dictyocha triacantha hastata Lemmermann, 1901, p. 259, pl. 10, figs. 16-17 (fide Loeblich et al., 1968, p. 117). Corbisema hastata hastata (Lemmermann) Bukry, 1975b, pp. 853-854. C. hastata minor
(Schulz) Bukry, 1975b, p. 854, pl. 1, fig. 10. Bukry, 1975a, pp. 716-717, pl. 1, fig. 5 .

Remarks. At Hole 511 and Site 512, there were small specimens of Corbisema hastata hastata with distinctly isosceles basal ring outlines. The short side is generally straight though it can also be moderately to severely indented. The long sides are moderately scalloped. The two spines at the end of the short side are generally perpendicular to it. In addition to the simple apical juncture of thin lateral rods usually shown by $C$. hastata hastata (Plate 2, Figs. 3-4), there are a small number of specimens which have an apical apparatus composed of flat, thickened, hyaline lateral rods (Plate 2, Fig. 2). It was impossible to distinguish Bukry's $C$. hastata minor from $C$. hastata hastata in the samples studied because of the variability in size and straightness of the short side and all specimens fitting this description were named $C$. hastata hastata.

This species is present sporadically in small quantities throughout Hole 511 and Site 512. It also occurs sporadically in the lower Oligocene of Hole 513A.

\section{Corbisema triacantha (Ehrenberg) Hanna, 1931}

(Plate 2, Figs. 5-7)

Dictyocha triacantha Ehrenberg, 1844a, p. 80 (fide Loeblich et al., 1968, p. 116). Corbisema triacantha (Ehrenberg) Hanna, 1931, pl. D, fig. 1 (fide Loeblich et al., 1968, p. 30). D. triacantha var. triacantha f. triacantha Glezer, 1966, pp. 243-244, pl. 4, figs. 1-6; pl. 5, figs. 2, 4, NOT 1, 3. D. lamellifera var. lamellifera Glezer, 1966 , vol. 7 , pp. $252-253$, pl. 10, figs. $11-13$, 14; pl. 32, fig. 3 .

Remarks. This species is recognized by its triangular basal ring, which lies in one plane, and by radial spines which can be short to moderately long. The outline of the basal ring can be straight or slightly convex. The radial spines generally extend straight out in the same line as the corresponding apical bar but may be slightly askew because the apical apparatus may be slightly twisted. Corbisema triacantha shows wide variability in wall structure. Specimens may be hollow throughout (Plate 2, Fig. 5), flatly hyaline (Plate 2, Fig. 7), or possessing a tubular basal ring and flat, hyaline apical apparatus (Plate 2, Fig. 6). These three different wall types were counted throughout Sites 511 and 512 and no difference was noted in the stratigraphic range of each type. This supports Busen and Wise's suggestion (1977) that $C$. triacantha exhibits a high degree of skeletal variability. It should be subdivided only after careful evaluation. C. triacantha is ubiquitous throughout Hole 511 and Site 512, though it is present in larger quantities at Hole 511. It is common to abundant through the lower portion of the lower Oligocene of Hole 513A.

\section{Aberrant forms of Corbisema}

(Plate 2, Figs. 8-9)

From Hole 512, two specimens which most closely resemble Corbisema are listed in this chapter as aberrant forms of Corbisema. Both specimens possess large, heavily silicified skeletons similar to those of Dictyocha grandis $\mathrm{n} . \mathrm{sp}$. and $D$. anguinea $\mathrm{n} . \mathrm{sp}$.. Their presence at Hole 512 could be related to this apparently unique flora seen throughout the site.

\section{Genus DICTYOCHA Ehrenberg, 1837, emend. Frenguelli, 1940}

This genus as originally defined by Ehrenberg (1837) contained the subsequently named genus Naviculopsis and many of the species of the genera Corbisema and Distephanus. The definition presently in use is the revised version of Frenguelli (1940) and Deflandre (1950).

The specimens of Dictyocha studied here all possess a tubular skeleton composed of a polygonal basal ring and an apical apparatus which consists of lateral rods and either an apical plate or apical rods. Supporting spines, if present, appear on the basal ring only.

Three new species of Dictyocha are presented here; all are restricted to Site 512 .

\section{Dictyocha aculeata (Lemmermann) Dumitriča, 1973}

Dictyocha fibula var. aculeata Lemmermann, 1901, p. 261, pl. 11, figs. 1-2. D. aculeata (Lemmermann) Dumitricà, 1973, p. 907, pl. 9, figs. 5-10. D. aculeata aculeata (Lemmermann) Bukry, 1980, pl. 1, figs. 1-3. D. aculeata subaculeata (Lemmermann) Bukry, 1980 , pl. 1, figs. 8-17.

Remarks. The species is rare in Quaternary sediments of Leg 71. Bukry's (1980) subspecies are not individually tabulated; however, our 
piston core studies support his contention that Dictyocha aculeata subaculeata is the ancestor of $D$. aculeata aculeata.

Dictyocha alta n.sp.

(Plate 17, Figs. 1-3, 5-9)

Description. The basal ring is usually rhomboid but may also be five- or six-sided. The total diameter (including spines) is usually 65 to $75 \mu \mathrm{m}$. The length of each side of the basal ring, between basal spines, varies from 31-36 $\mu \mathrm{m}$, whereas the distance between adjacent spine tips is generally $46-53 \mu \mathrm{m}$. Basal spines are thick, 9-12.5 $\mu \mathrm{m}$ long, and taper slightly.

The distinctive characteristic of the species is the great height of the apical apparatus, which usually reaches $35-45 \mu \mathrm{m}$ above the basal ring (Figs. 3, 5-7). Lateral rods rise from near the mid-point of the dorsal region of each side of the basal ring. The lateral rods extend almost vertically from the basal ring and toward their maximum height curve inward to form the apical apparatus (Fig. 5). Since the lateral rods also extend slightly outward, at mid-height they are beyond the outside of the basal ring by 2 to $4 \mu \mathrm{m}$ (Figs. 1, 2, 5-7, 9). In rhombic specimens, the lateral rods join to form a single 5-18 $\mu \mathrm{m}$ apical bar. Five-and six-sided specimens have two or three apical bars, each 3 to $6 \mu \mathrm{m}$ wide. Some lateral rods exhibit a strong sinuosity (Figs. 2, 6-7).

Holotype measurements. Total specimen diameter, $66 \mu \mathrm{m}$; length of basal ring sides between spines, $33 \mu \mathrm{m}$; spine tip to adjacent spine tip distance, $47 \mu \mathrm{m}$; basal spine length, $9 \mu \mathrm{m}$.

Holotype. Plate 17, Figure 1, USNM no. 340391.

Paratypes. Plate 17, Figure 2, USNM no. 340392; Plate 17, Figure 3, USNM no. 340393; Plate 17, Figure 4, USNM no. 340394; Plate 17, Figure 5, USNM no. 340395; Plate 17, Figure 6, USNM no. 340396; Plate 17, Figure 7, USNM no. 340397; Plate 17, Figure 8, USNM no. 340398; Plate 17, Figure 9, USNM no. 340399;

Type locality. DSDP Sample 513A-26,CC.

Stratigraphic occurrence. Common in the lower Oligocene Dictyocha deflandrei Zone and rare (reworked?) in Naviculopsis constricta Zone.

Authorship. Ciesielski.

Dictyocha anguinea n.sp.

(Plate 7, Figs. 1-5; Plate 8, Figs. 1, 3)

Description. This species possesses a fairly large polygonal basal ring $(74-87 \mu \mathrm{m})$ which may have four to six sides. Radial spines varying in length from $14-23 \mu \mathrm{m}$ are present at the corners of the basal ring. The apical apparatus is variable and consists of a serpentlike maze of apical bars. All members of the species have short accessory spines $(11-17 \mu \mathrm{m})$ which rise up almost vertically from the junctures of the apical bars with the basal ring into the plane of the apical apparatus. Members of this species vary not only in the number of sides of the basal ring but also in surface microstructure. Some specimens have none (Plate 7, Figs. 2, 5); others possess a complex system of ridges and bosses on their skeletons.

Remarks. Dictyocha frenguellii bears the closest resemblance to this species. However, $D$. anguine $a$ is considerably larger and heavier than $D$. frenguellii. In addition, $D$. anguinea rarely assumes the quadrangular form that characterizes $D$. frenguellii. $D$. anguinea is present only in the lower portion of the section at Site 512. In sieved corecatcher samples, it is present in Cores 512-13 through 512-19. In one sieved sample, 512-19,CC, 186 specimens of $D$. anguinea were encountered.

Stratigraphic occurrence. Middle Eocene.

Holotype measurements. Maximum diameter $86.5 \mu \mathrm{m}$; radial spine length $14.4 \mu \mathrm{m}$; accessory spine length $11 \mu \mathrm{m}$; thickness of the basal ring $6.6 \mu \mathrm{m}$; thickness of the apical apparatus $5.8 \mu \mathrm{m}$.

Holotype. Plate 7, Figure 3, USNM no. 340400.

Paratypes. Plate 7, Figure 1, USNM no. 340401; Plate 7, Figure 2, USNM no. 340402

Type locality. Falkland Plateau, Sample 512-18,CC.

Authorship. Ciesielski and Shaw.

Dictyocha aspera aspera (Lemmermann) Perch-Nielsen, 1975

(Plate 2, Figs. 10-12; Plate 3, Figs. 1-2, 4, 6, 9)

Dictyocha fibula Ehrenberg, 1839, p. 129 (fide Busen and Wise, 1977).

NOT D. fibula Ehrenberg, Glezer, 1966, pp. 264-270, pl. 13, figs.
6-9; pl. 14, figs. 1-9; pl. 15, figs. 4, 5, 8-10. NOT D. fibula Ehrenberg, Loeblich et al., 1968, p. 90, pl. 9, figs. 7-12. D. fibula perlaevis (Frenguelli) Bukry, 1975b, p. 855, pl. 3, fig. 5. D. aspera (Lemmermann) Perch-Nielsen, 1975, p. 686, pl. 4, figs. 10, 15, NOT fig. 9. D. fibula Ehrenberg, Busen and Wise, 1977, p. 713, pl. 5, fig. 1, 2, NOT pl. 4, figs. 7-8.

Remarks. One of the largest sources of confusion in the silicoflagellate literature is the distinction and subdivision of Dictyocha aspera aspera and $D$. fibula. Both species are tetragonal, possessing four radial spines and an apical bar. The confusion arises in determining whether the basal outline is square or rhombic, whether the apical bar is axially or transversely aligned with the long axis (in the case of a rhombic basal outline), and finally, whether the specimen possesses elevated spines at the distal ends of the apical struts.

In distinguishing the taxonomy of the specimens used in this study, we have attempted to rely, as much as is possible, on the original descriptions and have been guided by the principles of simplicity and clarity. It is oftentimes not possible when viewing four-sided silicoflagellates to distinguish between a square and rhombic basal outline without the aid of measurements. In this study, rhombic and square $D$. aspera aspera and D. fibula were tallied, but no biostratigraphic significance for either form emerged, and in the final computation of species ranges no distinction was made between these shapes.

$D$. aspera aspera is distinguished from $D$. fibula by its scalloped outline of the basal ring and parallel alignment of the apical bar with either axis of the specimen. No distinction is made between axial or transverse alignment of the apical bar with the long axis because, in the case of the square specimens, both axes are equal. Many workers have named specimens meeting this description as $D$. fibula, but the literature does not support this and the two forms are distinct enough to warrant two separate species. In Plate 3, Figures 6 and 9, the two forms of $D$. aspera aspera shown clearly demonstrate the skeletal variability of silicoflagellates. Both specimens are recognizable as $D$. aspera aspera, but both are also quite different from the original definition of $D$. aspera aspera.

D. aspera aspera occurs sporadically and in rare numbers throughout the cores at Hole 511. At Site 512, it occurs in common numbers consistently throughout the cores.

\section{Dictyocha aspera martinii Bukry, 1975b (Plate 5, Figs. 3, 6)}

Dictyocha aspera martinii Bukry, 1975b, p. 854, pl. 2, figs. 5-8. D. fibula formicata Bukry, 1975 b, p. 854 , pl. 3, figs. 7-8.

Remarks. This species is recognized by the elevated spines at the distal ends of the apical struts, extending above the margin of the basal ring. Bukry (1975b) defines this species as having the apical bar transverse to the long axis of the basal ring. However, as with $D$. aspera aspera, we made no distinction was made between axial and transverse alignment of this bar. We suggest that the two different subspecies which are distinguished on the basis of this alignment be further investigated before a definite distinction is made between these two similar forms.

D. aspera martinii is present only in Cores $511-2$ through $511-4$, and 513A-28, and 513A-30.

Dictyocha challengeri Martini and Müller, 1976

(Plate 5, Figs. 1-2, 4, 5, 9-10; Plate 6, Fig. 7)

Dictyocha challengeri Martini and Müller, 1976, p. 870, pl. 2, fig. 8; pl. 5 , fig. 10 ; pl. 8 , fig. 3 .

Remarks. This species is recognized by its large pentagonal form and simple apical structure. The outline of the basal ring is strongly concave at the connecting points with the apical rods and all specimens possess five radial spines of short to moderate length. The slightly raised apical structure is triradiate in the central part with two bifurcating rods and one straight rod leading to the basal ring. This structure results in one large, two medium, and two small apical windows. A pustulate surface ornamentation is visible on the skeletal surface. Two specimens of Dictyocha challengeri (Sample 512-14-1, 63-65 cm and Sample 512-8,CC) possess an apical structure consisting of an apical ring and five lateral rods (PI. 6, Fig. 7).

$D$. challengeri is present sporadically throughout Site 512 but occurs more consistently in and above Core 512-13. 


\section{Dictyocha deflandrei Frenguelli ex Glezer, 1966} (Plate 6, Fig. 8)

Dictyocha deflandrei Frenguelli, 1940, p. 65, figs. 14a-d (fide Loeblich et al., 1968, p. 34). D. deflandrei Frenguelli ex Glezer, 1966, p. 262. D. deflandrei var. deflandrei Glezer, 1966, p. 262, pl. 12, fig. 13,16 ; pl. 32 , fig. 4 .

Remarks. This species is recognized by its square to rhombic basal outline with almost straight sides. The apical apparatus is a square to $\mathrm{H}$-shaped flat hyaline plate, and all specimens possess four radial spines of equal length. Dictyocha deflandrei can be distinguished from Dictyocha sp. by the short apical bar and larger body size of the latter.

$D$. deflandrei is present throughout Hole 511, has one isolated occurrence in Core 512-11, and is present in Hole 513A from Sample $513 \mathrm{~A}-25, \mathrm{CC}$ to the base of the hole. In Hole 511, Dictyocha deflandrei is consistent and common in Core 511-9 and above, but rare and intermittent below. At Hole 513A it is common only within the Naviculopsis constricta-Corbisema archangelskiana Interval Zone.

\section{Dictyocha fibula Ehrenberg, 1839}

(Plate 4, Figs. 1-4)

Dictyocha fibula Ehrenberg, 1839, p. 129 (fide Loeblich et al., 1968, p. 90, figs. 7-12); (fide Glezer, 1966, pp. 264-270, pl. 13, figs. $6-9$, pl. 14 , figs. $1-9$, pl. 15 , figs. $4,5,8-10$ ). D. sp. 4 PerchNielsen, 1975 , p. 687 , pl. 5, fig. 18. D. cf. D. perlaevis Frenguelli, Perch-Nielsen, 1975 , p. 687 , p. 687 , pl. 5, fig. 16 , NOT figs. $9-10$, 17. D. sp. 2 Perch-Nielsen, 1975 , p. 687 , pl. 4, fig. 11, NOT fig. 12. D. fibula fibula Ehrenberg, Bukry, 1975 b, p. 854, pl. 3, figs. 2-3. D. fallacia Busen and Wise, 1977, p. 713, pl. 4, figs. 2-6. D. fibula augusta Bukry, 1976a, pp. 893-894, pl. 6, figs. 4-5, NOT figs. 1-3.

Remarks. This species is recognized by its square or rhombic straight-sided basal outline. Generally, the apical bar is not aligned parallel to either axis of the basal ring, though in some cases the apical bar does lie in the same line as one of the axes. All specimens possess four radial spines of moderate length.

In the literature, similar specimens have been given different names. However, Dictyocha fibula appears to be a species which is capable of a great deal of morphologic variation. Subdivision of this species should be done only with concrete evidence that its variants are of some value stratigraphically.

D. fibula is rarely present, sporadically, through Hole 511. At Site $512, D$. fibula occurs consistently throughout the site and is a major component of the silicoflagellate assemblage.

\section{Dictyocha cf. D. fibula \\ (Plate 4, Fig. 5)}

Remarks. A number of specimens resemble Dictyocha fibula in shape of the basal outline and characteristics of the apical apparatus. However, these specimens have shorter radial spines and possess very heavily silicified skeletons, similar to those seen in the two aberrant forms of Corbisema (Plate 2, Figs. 8-9) and congruous with the unique flora present at Site 512 .

The occurrence of $D$. cf. D. fibula is restricted to Cores 512-19 and Core $512 \mathrm{~A}-2$, where it occurs rarely and appears to have had no effect on the abundance of $D$. fibula.

\section{Dictyocha frenguellii Deflandre, 1950}

Dictyocha frenguellii Deflandre, 1950, p. 194, figs. 188-193.

Remarks. Dictyocha frenguelli, though usually common in the Oligocene (Ciesielski, 1975; Bukry, 1975a; Perch-Nielsen, 1975; and others), was found only in Sample 513A-21-1, 70-72 cm. Two specimens recorded as $D$. cf. $D$. frenguelli (Samples 513A-21-1, 70-72 cm and 513A-28-1, 17-19 cm) appear to be transitional forms between $D$. delfandrei and $D$. frenguellii; similar forms were noted by Ciesielsk (1975).

\section{Dictyocha grandis n.sp.}

(Plate 8, Figs. 2, 4-5; Plate 9, Figs. 1-4; Plate 10, Figs. 1-4)

Description. This huge species (109-148 $\mu \mathrm{m})$ is recognized by its heavy skeleton and rough surface ornamentation. The basal outline displays much variation and is generally hexagonal, though it can also be roughly pentagonal. The apical apparatus is slightly raised and also displays much variability. It generally has a thinner diameter $(4 \mu \mathrm{m})$ than the basal ring $(7 \mu \mathrm{m})$ and shows many different combinations of bifurcating struts, lateral rods, and apical junctures. Common intraspecific variations include specimens with a triradiate apical junction with three bifurcating struts (Plate 8, Figs. 2, 4-5), specimens with two bifurcating struts and two lateral rods, the latter located either opposite (Plate 9, Fig. 1) or adjacent (Plate 9, Figs. 2-3) to one another. Pentagonal specimens (Plate 9, Fig. 4) posses a triradiate apical junction with two bifurcating struts and one lateral rod.

All specimens possess short, irregular, radial spines (6.1-14.4 $\mu \mathrm{m})$ that lie in the plane of the basal ring and extend from the apices of the loosely hexagonal or pentagonal form. Along the inner margin of the basal ring, opposite the radial spines, some specimens have short spines $(2-4 \mu \mathrm{m})$ which also lie in the plane of the basal ring. In addition to these more or less regularly spaced radial spines, the species can also have smaller, irregularly placed spines along the periphery of the basal ring (Plate 8, Fig. 5; Plate 9, Fig. 3). Septae are present at some corners of the basal ring of some specimens.

All specimens possess micro-ornamentation on the surface of their skeletons. Generally, the basal ring exhibits parallel ridges and purtules. The apical apparatus may be unornamented or have pustulate surface micro-ornamentation.

Remarks. Dictyocha grandis does not resemble any silicoflagellate species presently recorded in the scientific literature, though Gombos (pers. comm. to P. F. Ciesielski, 1981) claims to have seen similar specimens in piston cores from the Falkland Plateau.

Though $D$. grandis displays much variability, and the possibility exists for extreme subdivision based on apical differences alone, we oppose the subdivision of the species. During the initial species counting, at least nine different $D$. grandis morphotypes were identified and recorded throughout Site 512 (Table 8). The resulting ranges of each of these different forms show little stratigraphic significance and to subdivide the species would serve no useful purpose.

Holotype measurements. Spine to spine diameter 134-148.3 $\mu \mathrm{m}$; minimum basal ring diameter $111.2 \mu \mathrm{m}$; radial spine length 12.4-16.5 $\mu \mathrm{m}$; inner spine length 8.2-10.7 $\mu \mathrm{m}$.

Holotype. Plate 8, Figure 4, USNM no. 340403.

Paratypes. 1. Plate 9, Figure 1, USNM no. 340404. 2. Plate 9, Figure 4, USNM no. 340405. 3. Plate 9, Figure 3, USNM no. 340406. 4. Plate 9, Figure 2, USNM no. 340407

Type locality. Falkland Plateau, Sample 512-9,CC.

Authorship. Ciesielski and Shaw,

\section{Dictyocha hexacantha Schulz, 1928} (Plate 4, Figs. 8-9)

Dictyocha hexacantha Schulz, 1928, p. 255, fig. 43 (fide Glezer, 1966, pp. 256-257, pl. 10, fig. 12). Corbisema hexacantha Deflandre, 1950, pp. 65-66, figs. 183-187 (fide Ciesielski, 1975, p. 659). Dictyocha hexacantha Schulz, Ciesielski, 1975, p. 659, pl. 6, figs. 10-11.

Remarks. This species is recognized by its six-sided basal ring, which has an inflated triangular form, and by its six radial spines, three of which are extensions of the apical apparatus. The radial spines all lie essentially in the plane of the basal ring, distinguishing it from Dictyocha spinosa. Three lateral rods form the apical apparatus and also lie in the plane of the basal ring or slightly above it. $D$. hexacantha appears to be a small, fragile species which is susceptible to dissolution. Most of the specimens encountered in this study were totally hyaline and were difficult to discern in the slides.

$D$. hexacantha is rare in Holes 511 and 512. Two solitary occurrences of this species were recorded in Cores 511-17 and 511-18, and it was seen in Cores 512-6, 512-8, and 512-9.

\section{Dictyocha pentagona (Schulz) Ciesielski, 1975}

(Plate 4, Figs. 12-13)

Dictyocha fibula var. pentagona Schulz, 1928, pp. 225-292 (fide Bukry, 1976a, p. 894). Glezer, 1966, pp. 268-269, pl. 15, figs. 1-3. D. pentagona (Schultz) Ciesielski, 1975, p. 659, pl. 7, figs. 6-7. D. variabilis (Hanna) Ciesielski, 1975, p. 660. pl. 7, figs. 12-15. D. deflandrei Frenguelli ex Glezer, Bukry, 1975a, pl. 1, fig. 8 ONLY.

Remarks. This species is recognized by its pentagonal basal ring with five radial spines which lie in the same plane as the basal ring. The apical apparatus in some specimens consists of five lateral rods 
joined in a flat apical plate whereas others show a basic plan of five lateral rods which meet to form a triradiate apical junction.

Dictyocha pentagona is rare in Holes 511, 512, and 513A. It occurs sporadically in Hole 511, Hole 513A, and Cores 512-15 through $512-19$.

\section{Dictyocha perlaevis Frenguelli, 1951}

Dictyocha perlaevis Frenguelli, 1951, p. 279, figs. 4b, c. D. perlaevis perlaevis Frenguelli, Bukry, 1979, p. 984, pl. 3, figs. 6-11.

Dictyocha pumila (Ciesielski) Bukry, 1978c

Dictyocha fibula var. pumila Ciesielski, 1975, p. 656, pl. 5, figs. 5-10; pl. 6, figs. 1-2. D. pumila (Ciesielski) Bukry, 1978c, p. 642 .

Dictyocha pygmaea (Ciesielski) n. comb.

Dictyocha aspera var. pygmaea Ciesielski, 1975, p. 655, pl. 4, figs. 1, $3,4,6$.

\section{Dictyocha quadria (Mandra) Martini and Müller, 1976}

$$
\text { (Plate 20, Figs. 3-5) }
$$

Hannaites quadria Mandra, 1969, p. 3, figs. 1-7. H. quadria Mandra, Perch-Nielsen, 1975 , p. 688 , pl. 8, figs. 9-10, 12, 14. Dictyocha quadria (Mandra) Martini and Müller, 1976, p. 870, pl. 2, fig. 4; pl. 10, figs. 1, 2; pl. 5, fig. 9.

Remarks. Only a few specimens of this species were found in the present study; these occur in Samples 513A-17-3, 22-24 cm and 513A$21-1,70-72 \mathrm{~cm}$. D. quadria occurs only in the Corbisema archangelskiana Zone of the upper Oligocene. All the specimens are characterized by an unequal division of the basal apparatus and an asymmetrical apical apparatus. The asymmetry of the skeleton and the co-occurrence of the species with $C$. archangelskiana suggest to us that $D$. quadria may be an intraspecific variation of $C$. archangelskiana.

\section{Dictyocha spinosa (Deflandre) Glezer, 1966} (Plate 5, Figs. 7-8)

Corbisema spinosa Deflandre, 1950, p. 65, figs. 178-182 ( fide Glezer, 1966). Dictyocha spinosa (Deflandre) Glezer, 1966, p. 256, pl. 10, figs. 6-8.

Remarks. This species is recognized by its triangular basal ring and by three lateral rods which are in a plane above the basal apparatus, joined only where they cross over the basal apparatus. The species has six needlelike radial spines, three of which are in the plane of the basal ring and extend from the apices of the triangular basal ring. The other three spines are extensions of the apical rods and extend beyond the basal ring.

Dictyocha spinosa is consistently present through Site 512 and is rare to few in abundance. There are two solitary occurrences of $D$. spinosa in Cores 511-6 and 511-9 and a single occurrence in Hole 513A-21-1, 70-72 cm.

\section{Dictyocha stelliformis n.sp.}

(Plate 6, Figs. 1-6)

Description. This species is recognized by its distinctly massive quadrate or stellate outline. Common to all members of the species is the presence of one or two short, tail-like, radial spines $(23-47 \mu \mathrm{m})$. At its other apices are thickened hyaline areas which resemble radial spines and range in size from apparent widenings of the basal ring to bulbous nodules. Generally, the quadrate specimens of Dictyocha stelliformis possess one tail-like spine and the stellate forms have two. The apical apparatus is considerably smaller in diameter $(6 \mu \mathrm{m})$ than the basal ring $(14 \mu \mathrm{m})$. Four or five lateral rods support a straight or chevron-shaped apical bar.

Remarks. The specimens of Dictyocha stelliformis seen in this study support the assertion of Martini and Müller (1976) that the genus Hannaites Mandra is a junior synonym of Dictyocha. Mandra's $H$. quadria, which is apparently the closest relation of $D$. stelliformis, appears to be an end-member in a continum of forms which has at its other end $D$. quadria Martini and Müller, 1976. Within the specimens of $D$. stelliformis present at Site 512, all degrees of variation between radial spines and spherical protuberances can be seen (see Plate 6 , Figs. 1-4). Therefore, at this time, the designation of the genus Han- naites, based on the presence of spherical protuberances on the basal ring, is not considered valid.

D. stelliformis has a restricted range in the middle Eocene at Site 512 , appearing only in and below Core 512-17.

Holotype measurements. Maximum diameter $204 \mu \mathrm{m}$; minimum diameter $165 \mu \mathrm{m}$; tail length $35 \mu \mathrm{m}$; nodule size length $14.4 \mu \mathrm{m}$; nodule size width $20.6 \mu \mathrm{m}$.

Holotype. Plate 6, Figure 4, USNM no. 340408.

Paratypes. 1. Plate 6, Figure 1, USNM no. 340409. 2. Plate 6, Figure 2, USNM no. 340410. 3. Plate 6, Figure 5, USNM no. 340411.

Type locality. Falkland Plateau, Sample $512-18-1,37-39 \mathrm{~cm}$.

Authorship. Shaw and Ciesielski.

\section{Dictyocha cf. D. stelliformis}

(Plate 6, Fig. 9)

One highly deformed specimen is present in Sample 511-12-1, 8-10 $\mathrm{cm}$. The corners of the basal ring are marked by distinctive spherical nodules and an apical bar is visible. Dictyocha stelliformis is the only species recorded from Leg 71 which has sperical nodules and, for this reason, the aberrant specimen is listed as a form compared to $D$. stelliformis.

\section{Dictyocha sp.}

(Plate 3, Figs. 3, 5, 7-8)

Dictyocha medusa Haeckel, Perch-Nielsen, 1974, p. 686, pl. 4, fig. 4, 5; pl. 15, figs. 5-7. D. aspera Lemmermann (in part), Perch-Nielsen, 1975 , p. 686 , pl. 4 , fig. 9 , NOT figs. 10,15 . D. sp. 2 PerchNielsen, 1975, p. 687 , pl. 4, fig. 12, NOT fig. 11.

Remarks. These specimens appear to be transitional between Dictyocha aspera aspera or D. fibula and $D$. deflandrei. In size, they are similar to $D$. aspera aspera; however, the apical bar is very short and appears to be approaching the platelike apical apparatus of $D$. deflandrei. This suggestion is supported by the location of Dictyocha sp. in Hole 511. Specimens with shortened apical bars occur consistently in Cores 511-6-11, with two isolated occurrences in Cores 511-13 and 511-16. The first consistent occurrence of $D$. deflandrei is in Core 511-9. D. aspera aspera and $D$. fibula occur sporadically throughout Hole 511; however, in Cores 511-11 through 16 D. aspera aspera occurs consistently in greater numbers. This relationship must be observed elsewhere before it will be possible to assume the evolution of $D$. deflandrei from a variant of $D$. aspera aspera or $D$. fibula.

\section{Aberrant forms of Dictyocha \\ (Plate 4, Figs. 6-7, 10-11)}

Several strange forms of Dictyocha in the Site 512 samples attest to the extreme skeletal variability of the silicoflagellates. In Figure 7 of Plate 4, a Dictyocha specimen with an incomplete basal ring can be seen. The specimen seen in Figure 6 is an excellent example of skeletal variability. Figure 10 is a Dictyocha specimen which has characteristics of $D$. aspera aspera, D. aspera martinii, and $D$. fibula along with several of its own incomparable characteristics. The specimen shown in Figure 11 is perhaps most closely related to $D$. quadria; however, its basal outline is not so concave as $D$. quadria and radial spines are absent.

\section{Genus DISTEPHANUS Stohr, 1880}

The genus Distephanus also exhibits much skeletal variability. The basal ring is polygonal with 4 to 11 corners and possesses radial spines of varying length. Distephanus differs from the genus Dictyocha in having an apical ring, smaller than the basal ring, supported by lateral rods. The apical ring has one or more apical windows, sometimes with accessory spines. Specimens with a hexagonal basal ring and an apical apparatus of bars only (no windows) are also assigned to Distephanus.

A new subspecies of $D$. crux, present only in the lower portion of Hole 511 , is described here.

\section{Distephanus antiquus Glezer, 1964}

(Plate 9, Fig. 5)

Distephanus antiquus Glezer, 1964, p. 57, pl. 2, figs. 6-9 (fide Martini and Müller, 1976, p. 871, pl. 7, figs. 17-18).

Remarks. This species is recognized by its seven-sided basal ring and apical ring. The apical ring is slightly smaller than the basal ring, 
causing the lateral rods to be almost perpendicular to both rings. $D$. antiquus is present in only one sample, 512-9-1, 92-94 cm.

\section{Distephanus boliviensis (Frenguelli) Bukry and Foster, 1973}

(Plate 10, Figs. 5, 8)

Dictyocha boliviensis Frenguelli, 1940, p. 44, fig. 4 (fide Loeblich et al., 1968, p. 83, pl. 9, fig. 3). Distephanus boliviensis Bukry and Foster, 1973, p. 287, pl. 4, figs. 1-3. D. boliviensis Frenguelli, Perch-Nielsen, 1975 , p. 687 , pl. 6 , fig. 11. D. cf. D. boliviensis Busen and Wise, 1977 , p. 714 , pl. 5, fig. 6 .

Remarks. This species is recognized by its large six- or seven-sided basal ring with four short radial spines extending from the corners. Generally, the number of sides of the apical ring equals the number of sides of the basal ring. However, in some Distephanus boliviensis sixand seven-sided basal rings were accompanied by five- and six-sided apical rings, respectively. Many of the specimens are more robust than the typical Miocene-Pliocene $D$. boliviensis, but there are also many which are identical to younger representatives of the species.

\section{Distephanus boliviensis major (Frenguelli) Ciesielski, 1975}

Dictyocha boliviensis Frenguelli, 1940 (in part), p. 44, fig. 4b-d. $D$. boliviensis var. major Frenguelli, 1951, p. 277, fig. 3a-c. Distephanus boliviensis major (Frenguelli) Ciesielski, 1975, p. 660, pl. 8, figs. 6-7. D. boliviensis var. binoculus (Frenguelli) Ciesielski, 1975 , p. 660 , pl. 8 , figs. $1-5$.

Remarks. The species exhibits a highly variable apical apparatus and includes all specimens of the Distephanus boliviensis group with a subdivided apical structure.

\section{Distephanus crux crux (Ehrenberg) Haeckel, 1887} (Plate 10, Figs. 6-7; Plate 11, Fig. 1)

Dictyocha crux Ehrenberg, 1840, p. 207 (fide Loeblich et al., 1968, p. 85, pl. 8, figs. 29-32). Distephanus crux var. crux (Ehrenberg) Haeckel, 1887, p. 1563 (fide Glezer, 1966, pp. 279-280). D. crux Haeckel f. longispina Schulz, Loeblich, et al., 1968, p. 120, pl. 24 , fig. 29. D. crux (Ehrenberg) Haeckel, Perch-Nielsen, 1975, p. 687, pl. 6, figs. 2-4. D. crux hannai Bukry, 1975 b, p. 855 , pl. 4, figs. 4-6. D. crux darwinii Bukry, 1976a, p. 895, pl. 7, figs. 4-11, NOT figs. 12-13. D. crux darwinii Bukry, Busen and Wise, 1977, p. 714, pl. 6, figs. 1-2. D. crux loeblichii Bukry, 1978a, p. 817, pl. 3, figs. 12-13; pl. 4, figs. 1-6.

Remarks. This species shows a large amount of morphologic variation. It is characterized by having a square to rhombic basal outline, four or five radial spines of varying length, and an apical ring of varying size and shape, supported by four lateral rods. During the initial identification and counting of the specimens, all the minor variations shown by Distephanus crux s.l. were tallied. The variants occur randomly in such low numbers as to indicate that subdivisions of the group would be of little value for biostratigraphy.

Distephanus crux crux is consistently present throughout Holes 511 and $513 \mathrm{~A}$ and forms a major component of the middle EoceneOligocene assemblage. At Site $512, D$. crux crux occurs rarely throughout the section.

\section{Distephanus crux paulii n. subsp.}

$$
\text { (Plate 11, Figs. 2-3, 5-6) }
$$

Distephanus mesophthalmus (Ehrenberg) Dumitriča, 1973, p. 850, pl. 6, fig. 9 ONLY. D. crux darwinii Bukry (in part), 1976a, p. 895 , pl. 7 , figs. $12-13$.

Description. This species has a square to rhombic basal ring 43-64 $\mu \mathrm{m}$ in diameter. It is similar to Distephanus crux crux except that it possesses small spines (4-8 $\mu \mathrm{m})$ which extend upward from either the basal or apical ring. These small spines can be located at the juncture of the lateral rods with the basal ring, in which case they extend into the plane of the apical ring. More frequently, they extend from the apical ring at some point between the junctures of the lateral rods with the apical ring.

Remarks. Dumitrica (1973) has recorded the occurrence of a vaguely similar species, Distephanus mesophthalmus, from a restricted occurrence in the middle and late Miocene of Leg 21. D. crux paulii differs from $D$. mesophthalmus by having larger spines and a heavier skeleton.
D. crux paulii has a restricted stratigraphic occurrence, with a brief appearance in Core 511-12 and a more consistent occurrence in and below Core 511-16.

Holotype measurements. Basal ring diameter 42.9-55.2 $\mu \mathrm{m}$; radial spine length 9.9-17.3 $\mu \mathrm{m}$; accessory spine length $6.6 \mu \mathrm{m}$.

Holotype. Plate 11, Figure 2, USNM no. 340412.

Paratypes. 1. Plate 11, Figure 3, USNM no. 340413. 2. Plate 11, Figure 6, USNM no. 340414.

Type locality. Falkland Plateau, Sample 511-17,CC.

Authorship. Shaw and Ciesielski.

\section{Distephanus polyactis (Ehrenberg) Deflandre, 1932}

Dictyocha polyactis Ehrenberg, 1839, p. 129. Distephanus polyactis Deflandre, 1932, p. 501, fig. 40

Remarks. This species was found primarily in the lower Pleistocene sediments of Hole 513 and Hole 514. In the Southern Ocean the acme of this species is a useful stratigraphic marker, occurring between the Jaramillo and Olduvai Subchronozones of the Matuyama Chronozone. At Site $514 \mathrm{D}$. polyactis is common within and immediately below the Olduvai Subchronozone.

\section{Distephanus pseudofibula (Schulz) Bukry, 1976b}

Dictyocha speculum f. pseudofibula Schulz, 1928, p. 262, fig. 51a-b. Distephanus speculum f. varians Gran and Braarud, 1935, p. 390, fig. 68A-B. D. varians (Gran and Braarud) Bukry, 1976b, p. 849. D. pseudofibula Bukry, 1976b, p. 848.

\section{Distephanus quinquangellus Bukry and Foster, 1973 (Plate 11, Figs. 4, 7, 9)}

Distephanus speculum pentagonus Lemmermann, 1901, p. 264, pl. 11, fig. 19 (fide Loeblich et al., 1968, p. 122). D. quinquangellus Bukry and Foster, 1973, p. 828, pl. 5, fig. 4. D. speculum var. pentagonus Lemmermann, Ciesielski, 1975, p. 660, pl. 10, figs. 4-8. D. raupii Bukry, 1976 a, p. 895 , pl. 7 , figs. $14-15$. D. speculum pentagonus Lemmermann, Busen and Wise, 1977, pl. 6, fig. 9.

Remarks. This species is characterized by its five-sided basal and apical rings. The five radial spines which extend from the corners of the basal ring range in size from less than to greater than the length of a side of the basal ring. The sides of the basal and apical rings are generally straight and may be slightly convex.

Distephanus quinquangellus occurs predominantly in Core 511-11 and above, although it is also recorded sporadically below Core 51111 and throughout Site 512. The species has a split range in the Oligocene of Hole 513A and occurs sporadically throughout Leg 71 Miocene-Quaternary sediments.

\section{Distephanus speculum s.l. (Ehrenberg) Haeckel, 1887 (Plate 11, Fig. 8)}

Dictyocha speculum Ehrenberg, 1839, p. 129, table, and pl. 4, fig. 10n (fide Glezer, 1966, v.7, pp. 282-286). Distephanus speculum speculum (Ehrenberg) Haeckel, 1887, no. 2, p. 1565, (fide Glezer, 1966, pp. 282-286). D. speculum s.l., Perch-Nielsen, 1975, p. 688, pl. 6 , figs. $12-13$; pl. 7 , figs. $16-17$.

Remarks. This small species is characterized by much intraspecific variation, and no attempt was made to differentiate between its many varieties in this study. The criteria used to identify the Distephanus speculum group are the small size of the species, the six-sided basal ring, the presence of six radial spines, and an apical apparatus which processes one or more apical windows.

At Site $512, D$. speculum s.l. is consistently present in moderate quantities. At Site 511 it is present only in several samples from Cores 1 and 2 .

\section{Distephanus cf. D. speculum}

$$
\text { (Plate 11, Fig. 10) }
$$

Remarks. This is a variation of Distephanus speculum which was noted but not counted. It is generally $1.5 \times$ larger than $D$. speculum but in all other ways the two are similar.

\section{Genus MESOCENA Ehrenberg, 1843, emend. Deflandre, 1950}

The genus Mesocena was originally defined (Ehrenberg, 1843) to include skeletons consisting of an elliptic, triangular, or polygonal 
basal ring with or without radial spines. Deflandre (1950) emended this definition to remove all forms whose skeletons represent an undeveloped Distephanus species.

In this study, the genus Septamesocena Bachmann is not recognized. M. apiculata is capable of possessing one to three septae, or it may have no septae. Dumitriča (1973) suggests the oblique orientation of the radial spines toward the plane of the basal ring as a criterion for distinguishing the genus Septamesocena; however, it would be a difficult trait to quantify and record accurately. It most certainly should not warrant a separate genus.

\section{Mesocena apiculata (Schulz) Hanna, 1931}

(Plate 12, Figs. 1-7)

Mesocena oamaruensis var. apiculata Schulz, 1928, p. 240. fig. 11 (fide Loeblich et al., 1968, p. 129). M. apiculata (Schulz), Hanna, 1931, no. 2, pl. D, fig. 3; Ling, 1972, p. 173, pl. 28, figs. 2-4. $M$. aff. apiculata (Schulz), Glezer, 1966, p. 282, pl. 28, fig. 5; pl. 33, fig. 7. Septamesocena apiculata (Schulz) (in part), Perch-Nielsen, 1974, pp. 689-670, pl. 10, figs. 2, 6-7, 10. M. apiculata curvata Bukry, 1976 b, p. 849 , pl. 2, figs. 15-16. M. apiculata inflata Bukry, 1978a, p. 786, pl. 3, figs. 1-3.

Remarks. This species is characterized by its variable triangular form with small radial spines at the apices. Forms with three septae and those with none to two septae were tallied, but (see Table 3 and Appendix). it was not possible to discern a distinct stratigraphic occurrence for many of these forms. At Hole 511, M. cf. apiculata 2 occurs consistently in and below Sample $511-9-3,80-81 \mathrm{~cm}$, but, this apparent range most likely results from the fact that we did not specifically look for the variation until Sample 511-9-3, 80-81 cm. The rare occurrences and indefinite ranges of both $M$. apiculata curvata Bukry and $M$. apiculata inflata Bukry indicate that these subspecies should be included as $M$. apiculata; they are treated as such herein.

The distinction between $M$. apiculata and $M$. oamaruensis is a more difficult one. The original definitions do not suffice to describe and distinguish the two species. Obviously, the triangular outline is not a distinctive enough criterion for identification. Similarly, spines are not exclusive to $M$. apiculata and cannot be used to distinguish the two species. In this study, the distinction is based on a combination of the wall structure and the presence or absence of spines. Of the two species, all specimens without spines fall under $M$. oamaruensis and all specimens with a rough texture and spines fall under $M$. apiculata.

As can be seen here, the genus Mesocena is particularly susceptible to morphologic variation and the subdivision of $M$. apiculata is ill-advised because of the difficulty encountered in identifying these forms.

$M$. apiculata is present fairly consistently, in rare to few numbers, throughout Hole 511. At Site 512, M. apiculata is present, in rare quantities, sporadically in Cores $512-13$ and above. It is generally common and consistently present throughout the Oligocene of Hole 513A.

\section{Mesocena bispicata n.sp.}

(Plate 20, Figs. 3, 6-8)

Description. The basal ring is six to eight-sided; seven-sided forms are the most numerous. In most specimens, all sides of the basal ring are unequal in length, varying between 20 and $27 \mu \mathrm{m}$. The total diameter (less spine length) is unusually longer in one direction than in another (Figs. 3 and 7 ) by up to $15 \%$. The diameter varies between 52 and $62 \mu \mathrm{m}$ and the diameter of the basal skeletal rods is $2.6-3.0 \mu \mathrm{m}$. Each corner of the basal ring possesses two tapering spines which diverge from opposite sides of the basal ring to form an angle of $\sim 45^{\circ}$ with the plane of the basal ring. Spine lengths vary between 4 and 10 $\mu \mathrm{m}$.

Holotype measurements. Total specimen diameter (less spines), 54-62 $\mu \mathrm{m}$; lengths of the sides of the basal ring, 23-27 $\mu \mathrm{m}$; spine lengths, 7.2 to $10.3 \mu \mathrm{m}$; skeletal thickness, 2.6 to $3.1 \mu \mathrm{m}$.

Holotype. Plate 20, Figure 3, USNM no. 340415.

Paratypes. Plate 20, Figure 6, USNM no. 340416; Plate 20, Figure 7, USNM no. 340417; Plate 20, Figure 8, USNM no. 340418.

Type locality. DSDP Hole 513A-26,CC.

Stratigraphic occurrence. Found only in the lower Oligocene Dictyocha deflandrei Zone.

Authorship. Ciesielski.

\section{Mesocena circulus (Ehrenberg) Ehrenberg, 1844a}

Dictyocha circulus Ehrenberg, 1840, p. 208, fide Loeblich et al., 1968; pp. 34,84 . Mesocena circulus (Ehrenberg) Ehrenberg, 1844, p. 65. Remarks. The Mesocena circulus plexus was not subdivided in the present study.

\section{Mesocena diodon Ehrenberg}

Mesocena diodon Ehrenberg, 1844a, pp. 71, 84 (fide Loeblich et al., 1968 , p. 54, 128); Ehrenberg, 1854, pl. 33, fig. 18; Loeblich et al., 1968 , pl. 27, fig. 4. M. crenulata var. diodon Lemmermann, 1901, p. 255 , pl. 10, figs. 1-2; Schulz, 1928, p. 236, fig. 1a, b; Gemeinhardt, 1930, p. 26, fig. 10a; Deflandre, 1932, fig. 4. Mesocena elliptica diodon Dumitriča, 1973, p. 905 , pl. 1, fig. 3.

Remarks. All specimens tabulated as Mesocena diodon are circular to elongate elliptical, have distal spines aligned with the major axes, and a surface ornamentation usually of prominent transverse crests and/or pustules. In Hole 513A the first occurrence of the species is immediately below a volcanic ash dated as $8.7 \pm 0.2 \mathrm{Ma}$ (see Site 513 site chapter) and thus approximately at the Chron $8 / \mathrm{Chron} 9$ boundary.

\section{Mesocena elliptica (Ehrenberg)}

Dictyocha elliptica Ehrenberg, 1840, p. 208. Mesocena elliptica (Ehrenberg) Ehrenberg, 1844a, p. 71, 84; (Ehrenberg) Bukry and Foster, 1973, p. 828, pl. 6, figs. 2-4. Ciesielski, 1975, p. 661.

\section{Mesocena oamaruensis Schulz, 1928}

(Plate 12, Figs. 8-10; Plate 13, Figs. 1-9; Plate 14, Figs. 1-2)

Mesocena oamaruensis Schulz, 1928, p. 240, fig. 10a, b (fide Loeblich et al., 1968, p. 129). M. oamaruensis Schulz, Perch-Nielsen, 1975, p. 688 , pl. 10 , figs. $12-13,20$.

Remarks. Specimens assigned to this species are characterized by having a loosely triangular outline. There is some variation in surface texture and in accessory spines. Generally, the specimens have a smooth, tubular, and roughly triangular basal ring (Plate 12, Fig. 8), but some have a rough surface texture (Plate 13, Figs. 1-5, 7-8). Another variation within this species is the presence of three small accessory spines on the basal ring (Plate 13, Fig. 9; Plate 14, Figs. 1-2). In addition to the more or less triangular forms displayed by Mesocena oamaruensis, roughly quadrangular (Plate 12, Figs. 9-10) and oval (pl. 13, Figs. 7-8) forms are also present. Two aberrant forms of M. oamaruensis are shown in Plate 13, Figures 5-6, displaying the extremely variable nature of the silicoflagellate skeleton.

$M$. oamaruensis is present fairly consistently throughout Hole 511, though rare to few in number. At Site 512, it is consistently present in smaller numbers. In Hole 513A the species is present only in the lower Oligocene (Cores 28-33).

\section{Mesocena occidentalis Hanna, 1931}

(Plate 13, Figs. 3-8)

Mesocena oamaruensis var. quadrangula Schulz, 1928, p. 240 , figs. 12-13 (fide Loeblich et al., 1968, p. 129). M. occidentalis Hanna, 1931 , pl. E, fig. 1 (fide Busen and Wise, 1977, p. 715). M. oamaruensis var. quadrangula Schulz, Ciesielski, 1975, p. 661, pl. 12, fig. 7.

Remarks. This species is recognized by its square to rhombic basal ring with a radial spine of variable length at each of the four corners. The surface texture can be smooth or rough. This species shows many aberrations and its skeleton appears to be very plastic (Plate 14, Figs. 5-7, Tables 3 and 6); it should be subdivided with caution.

Mesocena occidentalis is consistently present, though rare to few in number, throughout Sites 511 and 512. It is sparse to common in the lower Oligocene of Hole 513A.

\section{Mesocena quadrangula Ehrenberg ex Haeckel}

Mesocena quadrangula Ehrenberg ex Haeckel, 1887, p. 1556; Lemmermann, 1901, pl. 10, figs. 5-7 (fide Loeblich et al., 1968, p. 57). M. quadrangula Ehrenberg ex Haeckel Bukry, 1978b, p. 819, pl. 7, figs. 1-5.

Remarks. This species was found only in the Pleistocene sediments of Core 514-4. The restricted range of Mesocena quadrangula brackets the Jaramillo Subchronozone. 


\section{Aberrant forms of Mesocena}

(Plate 14, Figs. 9-10)

Several aberrant forms of Mesocena are present at Hole 512. A sixsided form of Mesocena occidentalis is present in Sample 512-16-2, $15-17 \mathrm{~cm}$ and is shown in Plate 14, Figure 9. In Sample 512-11-1, 74$76 \mathrm{~cm}(\mathrm{Pl} .13$, Fig. 10) an oddly shaped Mesocena, with an indented, broadly convex basal ring is present.

\section{Genus NAVICULOPSIS Frenguelli, 1940}

The genus Naviculopsis is defined by a bilaterally symmetrical, boat-shaped basal ring with two radial spines on the poles. In most species, the sides of the basal ring are flattened at the juncture with the apical apparatus. In some species, the two apices of the basal ring are also flattened. The apical apparatus consists of a bar of varying thickness. It can range in width from less than the diameter of the tubular portion of the basal ring to a size large enough to fill the entire body cavity.

\section{Naviculopsis biapiculata (Lemmermann) Frenguelli, 1940}

(Plate 14, Figs. 11-13; Plate 15, Figs. 1-3)

Dictyocha navicula var. biapiculata Lemmermann, 1901, p. 258, pl. 10, figs. 14-15 (fide Loeblich et al., 1968, p. 105). Naviculopsis biapiculata (Lemmermann) Frenguelli, 1940, p. 60, fig. 11c,d (fide (Loeblich et al., 1968, p. 58). N. biapiculata var. biapiculata Glezer, 1966, vol. 7, p. 274, pl. 16, figs. 2-5. N. biapiculata (Lemmermann) Ling, 1972, pp. 181-182, pl. 30, figs. 1-4. N. biapiculata Bukry, 1976b, p. 349, pl. 2, figs. 15-16.

Remarks. This species shows a wide degree of variability in size and shape. It is recognized by its oval-shaped basal ring, two equal basal spines, and an arched apical bar. There is much variation in the shape of the oval basal ring, which is sometimes concave centrally, and in the length of the two basal spines. The thickness of the apical bar is always less than or equal to the width of the tubular part of the basal ring, distinguishing Naviculopsis biapiculata from $N$. constricta.

$N$. biapiculata is consistently present throughout the Eocene-lower Miocene of Sites 511, 512, and 513, in all of which it is a major component of the assemblage.

\section{Naviculopsis constricta (Schulz) Frenguelli, 1940}

$$
\text { (Plate 15, Figs. 4-8) }
$$

Dictyocha navicula var. constricta Schulz, 1928, p. 246, fig. 21 (fide Loeblich et al., 1968, p. 58). Naviculopsis constricta (Schulz), Frenguelli, 1940, fig. 11a,b (fide Loeblich et al., 1968, p. 58). N. biapiculata var. constricta (Schulz) Glezer, 1966, pp. 276-277, pl. 17, fig. 4. N. biapiculata var. minor Glezer, 1966, pp. 274-276, pl. 16 , figs. 6-8; pl. 17, figs. 1-3, 6. N. constricta (Schulz) Ling, 1972, pp. $182-183$, pl. 30 , figs. $5-8$.

Remarks. This species is recognized by its oval-shaped basal ring, two equal polar spines, and a wide apical bar. It is very similar to Naviculopsis biapiculata in the shape of the basal ring and the presence of two equal polar spines. However, $N$. constricta is distinguished from $N$. biapiculata by a wider apical bar, which is greater in width than the tubular part of the basal ring and may occupy up to one-third the length of the body ring opening. The basal ring is commonly, though not always, constricted where it joins the apical bar.

$N$. constricta is consistently present, rare to few in number, below Core 3 in Hole 511 and in Cores $31-33$ of Hole 513A. At Site 512, N. constricta is consistently present and is the dominant component of the assemblage throughout the section.

\section{Naviculopsis foliacea Deflandre, 1950 \\ (Plate 16, Figs. 1-7, 10, 12)}

Naviculopsis foliacea Deflandre, 1950, p. 204, figs. 235-240 (fide Loeblich et al., 1968, pp. 134-135).

Remarks. This species is recognized by its flat apical plate, which covers more than one-third the length of the body opening. The polar spines are usually shorter than those of Naviculopsis biapiculata and $N$. constricta; however, they can be greater than one-half the length of the body. Most of our specimens differ slightly from all previously reported $N$. foliacea. In these specimens, the flattened apical plate covers a small portion of the two distal ends of the body opening in addition to the central region. There is no difference in the stratigraphic range of this aberrant form and, for this reason, it was tabulated as $N$. foliacea. $N$. foliacea is present only at Site 512 where it is a minor, though consistent, part of the assemblage.

\section{Naviculopsis nordica hyalina Bukry, 1976b (Plate 15, Figs. 9-13)}

Naviculopsis nordica hyalina Bukry, 1976b, p. 849, pl. 2, figs. 8-10.

Remarks. This species was previously thought to be provincial to the Norwegian-Greenland Sea. It is recognized by its narrow elongate basal ring and imperforate apical plate, which fills the entire central area. The two polar spines are shorter than the basal ring and form a continuous line with the outline of the body ring. Naviculopsis nordica hyalina is present only at Site 512, where it is rare and occurs only sporadically throughout the section.

\section{Naviculopsis punctilia Perch-Nielsen, 1976}

(Plate 15, Fig. 14)

Naviculopsis punctilia Perch-Nielsen, 1976, p. 36, figs. 1, 32. N. ponticula [sic] Perch-Nielsen, Martini and Müller, 1976, pp. 873-874, pl. 12, figs. 1-2.

Remarks. This species is recognized by its elliptical basal ring and distinctive apical apparatus which consists of a flat apical bar supported by four flat lateral rods. A solitary occurrence of $N$. punctilia was recorded from Core 5 at Hole 511 .

\section{Naviculopsis trispinosa (Schulz) Glezer, 1966}

(Plate 16, Figs. 8, 11)

Dictyocha navicula var. trispinosa Schulz, 1928, p. 246, fig. 23a,b (fide Loeblich et al., 1968, p. 106). Naviculopsis biapiculata f. trispinosa (Schulz) Frenguelli, 1940, fig. 11e (fide Loeblich et al., 1968). N. trispinosa (Schulz) Glezer, 1966, pp. 277-278, pl. 17, fig. 7.

Remarks. This species is recognized by its apical spine that projects from the middle of the apical bar and resembles the two polar spines, but may be shorter. The apical spine may be perpendicular to the plane of the body ring or may project at an angle.

Naviculopsis trispinosa is consistently present throughout Hole 511. Above Core 511-12 it is a major component of the assemblage. At Site $512, N$. trispinosa is sporadically present in small numbers. The species is present throughout most of the Oligocene of Hole $513 \mathrm{~A}$, where it is rare to sparse in the upper Oligocene and common to abundant in the lower Oligocene.

\section{Aberrant form of Naviculopsis (Plate 16, Fig. 9)}

In general, the Naviculopsis species seen in this study do not display as many bizarre aberrations as other genera present in Hole 511 and at Site 512. One aberrant form of Naviculopsis (Plate 16, Fig. 9), from Sample 511-6,CC, appears to have characteristics of $N$. trispinosa, $N$. constricta, and $N$. punctilia. It displays, once again, the truly remarkable variability of the silicoflagellate skeleton.

\section{Incertae Sedis}

Genus MACRORA Hanna, 1932

(Synonym: PSEUDOROCELLA Deflandre, 1938)

Macrora barbadensis (Deflandre) Bukry, 1977

(Plate 18, Figs, 7-8)

Pseudorocella barbadensis Deflandre, 1938 (in part), p. 91 (fide Loeblich et al., 1968, p. 139, pl. 33, figs. 4-13, 15-19 [not 14]). Macrora barbadensis (Deflandre) Bukry, 1977, p. 832, pl. 2, figs. 3-8.

Remarks. Macrora barbadensis was found in only four samples of Hole 513A between Samples 513A-13-2, 17-19 cm and 513A-17-3, 22$24 \mathrm{~cm}$. The species occurs in the lower Miocene Naviculopsis biapiculata Zone and the upper portion of the Corbisema archangelskiana Zone.

\section{Macrora stella (Axpeitia) Hanna, 1932}

(Plate 18, Fig. 6)

Pyridicula (??) stella Azpeitia, 1911, pp. 150, 152, 213, pl. 1, fig. 1. Macrora stella (Azpeitia) Hanna, 1932, p. 196, pl. 12, fig. 7. Pseudorocella corona Deflandre, Bukry, 1975a, p. 871, pl. 7, figs. 8-9. 
Remarks. This species was found in only two samples from Hole 513A: Samples 513A-16-3, 23-25 cm and 513A-17-3, 22-24 cm. It occurs in the upper Corbisema archangelskiana Zone, immediately below the Oligocene/Miocene boundary. Macrora stella was noted to have a similar stratigraphic occurrence elsewhere; Bukry (1975a and 1977) found it present in the lower Miocene at Site 338 in the Norwegian-Greenland Sea and at Site 278 in the southwest Pacific. Specimens from Site 513A have fewer central pores than specimens of similar ages from Site 278.

\section{ACKNOWLEDGMENTS}

Dr. Hsin Yi Ling of Northern Illinois University and Dr. Sherwood W. Wise, Jr. are gratefully acknowledged for their critical review of the manuscript. Text figures were prepared by Ms. Barbara Daniel. Partial financial support for this study was provided by NSF Grant DPP-8113147 to Dr. M. T. Ledbetter and Dr. P. F. Ciesielski and by the University of Georgia Levy Fund for marine geology research.

\section{REFERENCES}

Azpeitia, D. F. M., 1911. La diatomología espànola en los comienzos del siglo XX. Assoc. Esp. Prog. Cien. Congr. de Zargoza, 4(pt. 2, sec. 3).

Bukry, D., 1975a. Coccolith and silicoflagellate stratigraphy near Antarctica, Deep Sea Drilling Project, Leg 28. In Hayes, D. E., Frakes, L. A., et al., Init. Repts. DSDP, 28: Washington (U.S. Govt. Printing Office), 709-723.

1975b. Silicoflagellate and coccolith stratigraphy, Deep Sea Drilling Project, Leg 29. In Kennett, J. P., Houtz, R. E., et al., Init. Repts. DSDP, 29: Washington (U.S. Govt. Printing Office), $845-872$.

1976a. Cenozoic silicoflagellate and coccolith stratigraphy, South Atlantic Ocean, Deep Sea Drilling Project Leg 36. In Hollister, C. D., Craddock, C., et al., Init. Repts. DSDP, 35: Washington (U.S. Govt. Printing Office), 885-917.

, 1976b. Silicoflagellate and coccolith stratigraphy, Norwegian-Greenland Sea, Deep Sea Drilling Project Leg 38. In Talwani, M., Udintsev, G., et al., Init. Repts. DSDP, 38: Washington (U.S. Govt. Printing Office), 843-855.

1977. Coccolith and silicoflagellate stratigraphy, South Atlantic Ocean, Deep Sea Drilling Project Leg 39. In Supko, P. R., Perch-Nielsen, K., et al., Init. Repts. DSDP, 39: Washington (U.S. Govt. Printing Office), 825-839.

1978a. Cenozoic coccolith, silicoflagellate, and diatom stratigraphy, Deep Sea Drilling Project Leg 44. In Benson, W. E., Sheridan, R. E., et al., Init. Repts. DSDP, 44: Washington (U.S. Govt. Printing Office), 807-863.

1978b. Cenozoic silicoflagellate and coccolith stratigraphy, Northwestern Atlantic Ocean, Deep Sea Drilling Project Leg 43. In Benson, W. E., Sheridan, R. E., et al., Init. Repts. DSDP, 44: Washington (U.S. Govt. Printing Office), 775-805.

1978c. Cenozoic silicoflagellate and coccolith stratigraphy, southeastern Atlantic Ocean, Deep Sea Drilling Project Leg 40. In Bolli, H. M., Ryan, W. B. F., et al., Init. Repts. DSDP, 40: Washington (U.S. Govt. Printing Office), 635-649.

1979. Comments on opal phytoliths and stratigraphy of Neogene silicoflagellates and coccoliths at Deep Sea Drilling Project Site 397 off northwest Africa. In Luyendyk, B. P., Cann, J. R., et al., Init. Repts. DSDP, 49: Washington (U.S. Govt. Printing Office), 977-1010.

1980. Silicoflagellate biostratigraphy and paleoecology in the eastern equatorial Pacific, Deep Sea Drilling Project Leg 54. In Rosendahl, B. R., Hekinian, R., et al., Init. Repts. DSDP, 54: Washington (U.S. Govt. Printing Office), 545-573.

Bukry, D., and Foster, J. H., 1973. Silicoflagellate and diatom stratigraphy, DSDP Leg 16. In van Andel, Tj. H., Heath, G. R., et al., Init. Repts. DSDP, 16: Washington (U.S. Govt. Printing Office), 815-871.

1974. Silicoflagellate zonation of upper Cretaceous to lower Miocene deep-sea sediment. J. Res. U.S. Geol. Surv., 2:303-310.

Burckle, L. H., 1977. Pliocene and Pleistocene diatom datum levels from the equatorial Pacific. Quat. Res., 7:330-340.
Burger, W. H., and Roth, P. H., 1975. Oceanic micropaleontology: Progress and prospect. Rev. Geophys. Space Phys., 13:561-585, 624-635.

Busen, K. E., and Wise, S. W., Jr., 1977. Silicoflagellate stratigraphy, Deep Sea Drilling Project, Leg 36. In Barker, P. F., Dalziel, I. W. D., et al., Init. Repts. DSDP, 36: Washington (U.S. Govt. Printing Office), 697-743.

Ciesielski, P. F., 1975. Biostratigraphy and paleoecology of Neogene and Oligocene silicoflagellates from cores recovered during Antarctic Leg 28, Deep Sea Drilling Project. In Hayes, D. E., Frakes, L. A., et al., Init. Repts. DSDP, 28: Washington (U.S. Govt. Printing Office), 625-691.

1978. The Maurice Ewing Bank of the Malvinas (Falkland) Plateau: Depositional and erosional history and its paleoenvironmental implications [Ph.D. dissert.]. Florida State University, Tallahassee.

1980. On the age of the Neogene deposits at Site 329 (DSDP Leg 36): Discussion. Rev. Esp. Micropaleontol., 12:87-97.

Ciesielski, P. F., and Weaver, F. M., 1974. Early Pliocene temperature changes in the Antarctic Seas. Geology, 2:511-515.

Deflandre, G., 1932. Sur la systématique des silicoflagelles. Soc. Bot. Fr. Bull., 79:494-506.

1938. Sur deux microfossiles siliceux enigmatiques (silicoflagellidées?). Soc. Fr. Microsc. Bull., 7:90-96.

1950. Contribution a l'etude des silicoflagellidees actuels et fossiles. Microscropie, 2:72-108.

Dumitrică, P., 1973. Paleocene, late Oligocene and post-Oligocene silicoflagellates in southwestern Pacific sediments cored on DSDP Leg 21. In Burns, R. E., Andrews, J. E., et al., Init. Repts. DSDP, 21: Washington (U.S. Govt. Printing Office), 837-883.

Ehrenberg, C. G., 1839. Uber die Bildung der Kreidefelsen und des Kreidemergels duch unsichtbare Organismen. Abh. K. Akad. Wiss. Berlin, pp. 59-148.

1840. 274 Blatter von ihm selbst ausgefuhrter Zeichnungen von ebenso vielen Arten. Ber. K. Preuss. Akad. Wiss. Berlin, pp. 197-219.

1843. Verbreitung und Einfluss des midroskopischen Lebens in Sud- und Nord-Amerika, Abh. K. Akad. Wiss. Berlin, pp. 291-445.

1844a. Mitteilung uber zwei neue Lager von Gebirgsmassen aus Infusorien als Meeres-Absatz in Nord-Amerika und eine Vergleichung derselben mit den organischen Kreidegebilden in Europa und Afrika. Ber. K. Preuss. Akad. Wiss. Berlin, pp. 57-97.

$1844 \mathrm{~b}$. Vorlaufige Nachricht uber das Kleinste Leben im Weltmeer am Sudpol in den Meerestiefen. Monatsber. Akad. Wiss. Berl., pp. 3-29.

1854. Mikrogeologie der Erden und Felsen schaffende Wirken des umsichtbar kleinen selbstandigen Lebens auf der Erde: Leipzig (Leopold Voss).

Frenguelli, J., 1940. Consideraciones sobre los silicoflagelados fosiles. Rev. Mus. La Plata Paleontol., 2:37-112.

1951. Silicoflagelados del Tripoli de Mejillones (Chile). Physis (Buenos Aires), 20:272-284.

Gemeinhardt, K., 1930. Silicoflagellatae. In Rabenhorst, L. (Ed.), Kryptogamen-Flora von Deutschland, Osterreich und der Schweitz (Vol. 10, pt. 2): Leipzig (Akademische Gesellschaft): 1-87.

1931a. Die Silicoflagellaten der deutschen Sudpolar-Expedition 1901-1903. Deutsche Sudpolar-Expedition 1901-1903, 20: 221-258.

1931b. Organismen formen auf der Grenze zwischen Radiolarien und Flagellaten. Ber. Dtsch. Bot. Ges., 49(2):103-110.

Glezer, Z. I., 1964. Novye kremnevye zhgutikovye vodorosl: paleogena SSSR. Akad. Nauk. SSSR, Novosti Sistematiki Rasteniy, Otdel. Ottisk, p. 57, pl. 2, figs. 6-9.

1966. Silicoflagellatophycae. In Gollenbakh, M. M. (Ed.), Cryptogamic Plants of the U.S.S.R. (Akad. Nauk. S.S.S.R., V. A. Komarova Bot. Inst.). Translated from the Russian by Israel Program for Scientific Translations: Jerusalem (Keter Press, 1970), p. 363.

Gordon, A. L., Georgi, D. T., and Taylor, H. W., 1977. Antarctic Polar Front Zone in the western Scotia Sea, summer 1975. Phys. Oceanogr., 7:309-328. 
Gran, H. H., and Braarud, T., 1935. A quantitative study of the phytoplankton in the Bay of Fundy and the Gulf of Maine (including observations on hydrography, chemistry and turbidity). J. Biol. Board Can., 1:280-467.

Haeckel, E., 1887. Report on the Scientific Results of the Voyage of H.M.S. Challenger during the years 1873-76. Zoology, Vol. 18. Report on the Radiolaria: London (Eyre and Spottiswoode).

Hanna, G. D., 1928. Silicoflagellatae from the Cretaceous of California. J. Paleontol., 1(4):259-264.

1931. Diatoms and silicoflagellates of the Kreyenhagen Shale. Min. in Calif., pp. 197-201.

1932. The diatoms of Sharktooth Hill, Kern County, California. Proc. Calif. Acad. Sci., 20:161-263.

Haq, B. U., and Riley, A., 1976. Antarctic silicoflagellates from the southeast Pacific, Deep Sea Drilling Project Leg 35. In Hollister, C. D., Craddock, C., et al., Init. Repts. DSDP, 35: Washington (U.S. Govt. Printing Office), 673-691.

LaBrecque, J. L., Kent, D. V., and Cande, J. C., 1977. Revised magnetic polarity time scale for late Cretaceous and Cenozoic time. Geology, 5:330-335.

Lemmermann, E., 1901. Silicoflagellaten. Ergebnisse einer Reise nach dem Pazifik. Ber. Dtsch. Bot. Ges., 19(1):247-271.

Ling, H. Y., 1972. Upper Cretaceous and Cenozoic silicoflagellates and ebridians. Bull. Am. Paleontol., 62:135-229.

Loeblich, A. R., III, Loeblich, L. A., Tappan, H., and Loeblich, A. R., Jr., 1968. Annotated Index of Fossil and Recent Silicoflagellates and Ebridians with Descriptions and Illustrations of Validly Proposed Taxa. Geol. Soc. Am. Mem. 106.

Ludwig, W. J., Krashenninnikov, V. A., and Leg 71 Shipboard Scientific Party, 1980. Tertiary and Cretaceous paleoenvironments in the southwest Atlantic Ocean: Preliminary results of Deep Sea Drilling Project Leg 71. Geol. Soc. Am. Bull., Part I, 91:655-664.

Mandra, Y. T., 1969. Silicoflagellates: A new tool for the study of Antarctic Tertiary climates. J. Antarct. Res., 4:172-174.

Martini, E., 1974. Silicoflagellate zones in the Eocene and early Oligocene. Senckenbergiana Lethaea, 54:527-532.

Martini, E., and Müller, C., 1976. Eocene to Pleistocene silicoflagellates from the Norwegian-Greenland Sea (DSDP Leg 38). In Talwani, M., Udintsev, G., et al., Init. Repts. DSDP, 38: Washington (U.S. Govt. Printing Office), 857-895.

Ness, G., Levi, S., and Couch, R., 1980. Marine magnetic anomaly timescales for the Cenozoic and late Cretaceous: A precis, critique, and synthesis. Rev. Geophys. Space Phys., 18:753-770.

Perch-Nielsen, K., 1975. Late Cretaceous to Pleistocene silicoflagellates from the southern Southwest Pacific, DSDP Leg 29. In Kennett, J. P., Houtz, R. E., et al., Init. Repts. DSDP, 29: Washington (U.S. Govt. Printing Office), 677-721.

1976. New silicoflagellates and a silicoflagellate zonation in north European Paleocene and Eocene diatomites. Bull. Geol. Soc. Den., 25:27-40.

Schulz, P., 1928. Beitrage zur Kenntnis fossiler und rezenter Silicoflagellaten. Bot. Arch., 21(2):225-292.

Stohr, E., 1880. Die Radiolarienfauna der Tripoli von Grotte, Provinz Girgenti in Sicilien. Paleontographica, 26:69-124.

Stradner, H., 1961. Uber fossile Silicoflagelliden und die Moglichkeit ihrer Verwendung in der Erdölstratigraphie. Erdöl Kohle, 14(2): $87-92$.

Tsumura, K., 1963. A systematic study of Silicoflagellatae. J. Yokohama Municipal Univ., Ser. C-45, 146:1-84.

Weaver, F. M., 1976. Late Miocene and Pliocene radiolarian paleobiogeography and biostratigraphy of the Southern Ocean [Ph.D. Dissert.]. Florida State University, Tallahassee.

\section{APPENDIX}

Skeletal Descriptions or Plate References of Silicoflagellate Morphotypes Listed in Tables 3 and 5

Corbisema cf. C. triacantha

1 Solid, hyaline skeleton

2 Solid, hyaline apical apparatus

Dictyocha cf. aspera aspera

1 Very short apical bar

2 Small fat hyaline apical bar

3 Dark skeleton

4 With five radial spines

5 With axial alignment of apical bar

6 With twisted lateral rods

7 Rhombic-shaped basal apparatus

8 With two long and two moderate-length basal spines

9 Five-sided basal ring

Dictyocha $\mathrm{cf}$. $D$. deflandrei

1 Dark skeleton

Dictyocha $\mathrm{cf}$. D. fibula

1 Heavily silicified skeleton

2 Heavily silicified pentagonal skeleton

Dictyocha grandis var.

A Plate 8, Figs. 2, 4-5

B Plate 9, Fig. 4

C Plate 9, Fig. 1

D Plate 9, Figs. 2-3

E Plate 10, Fig. 3

F Pseudo-hexagonal skeleton, complex apical apparatus

G Plate 10, Fig. 2

$\mathrm{H}$ Plate 10, Fig. 4

I Plate 10, Fig. 1

Dictyocha cf. D. stelliformis

1 Plate 6, Fig. 9

2 Plate 6, Fig. 6

3 No tails, nodules, or spines

4 Plate 6, Figs. 1-3

5 Bloated triangular shape, with nodules and spines

Distephanus cf. D. boliviensis

1 Six-sided basal ring, 5-sided apical ring

2 Seven-sided basal ring

3 Deformed apical ring

Distephanus cf. D. crux crux

1 Thickened hyaline area on basal ring where struts adjoin

2 Five-sided apical ring

3 Rhombic basal outline, two long basal spines

4 Rhombic basal outline

Mesocena $\mathrm{cf} . \mathrm{M}$, apiculato

1 Bell-shaped

2 Without septae

3 Spines asymmetrically placed

4 Six-sided

Mesocena $\mathrm{cf}$. M. oamaruensis

1 Rough skeletal ornamentation (pl. 13, fig. 1-5)

2 With small spines (pl. 13, fig. 9; pl. 14, fig. 1, 2)

3 Roughly square outline (pl. 12, fig. 9, 10)

4 Roughly oval outline (pl. 13, fig. 7, 8)

5 Rough skeletal ornamentation and oval outline

6 Rough skeletal ornamentation and square outline

Mesocena $\mathrm{cf}$. M. occidentalis

1 Not square (Plate 14, Figs. 6-7)

2 Six-sided (Plate 14, Fig. 9)

3 Heavily silicified skeleton (Plate 14, Fig. 3)

Naviculopsis cf. $N$. biapiculata

1 Large triangular hyaline area at juncture of apical bar with basal ring

Naviculopsis cf. N. foliacea

1 Plate 16, Figs. 3-5, 7, 10, 12

Naviculopsis cf. $N$. trispinosa

1 Plate 16, Fig. 9 


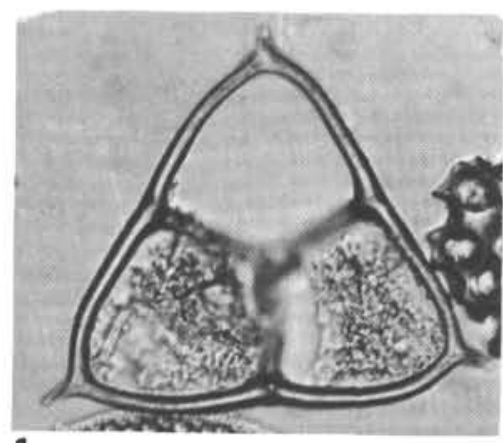

1
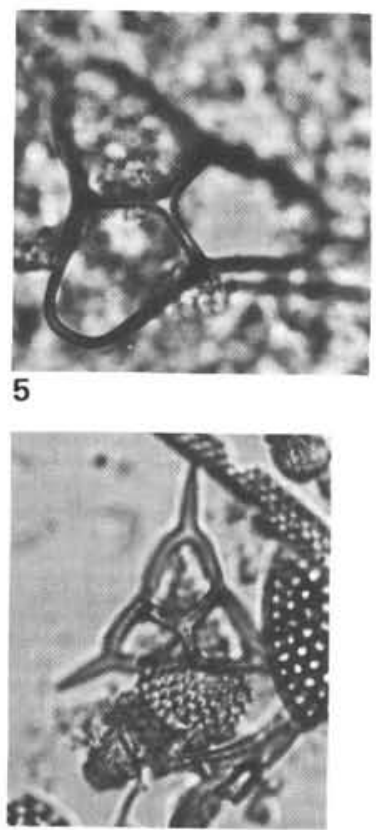

9

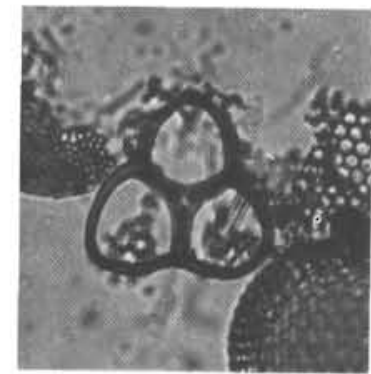

13

6

10

14

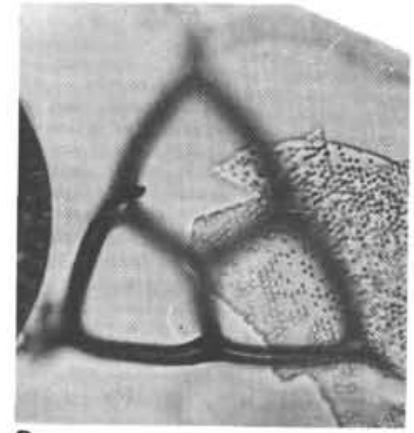

2
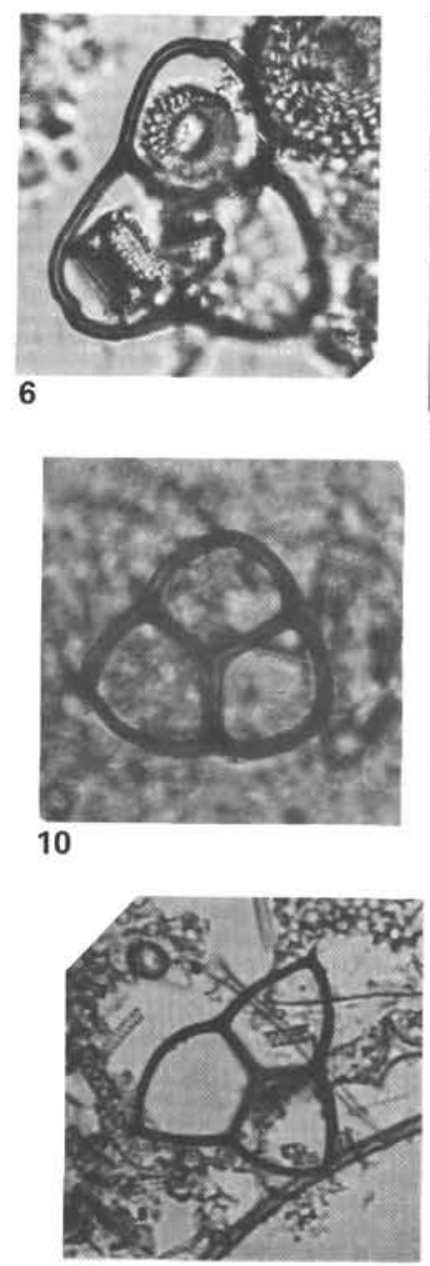
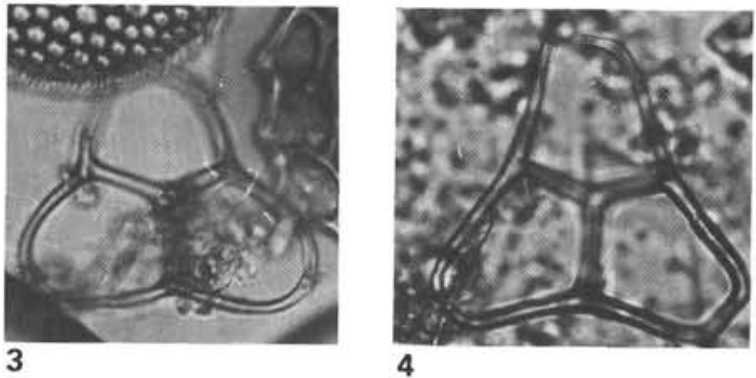

3

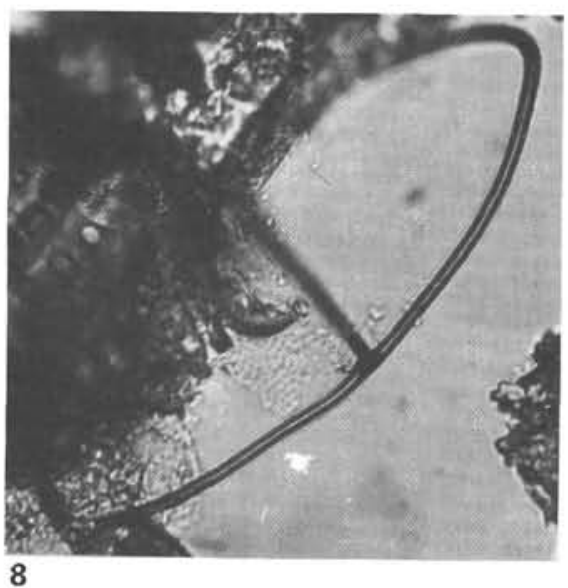

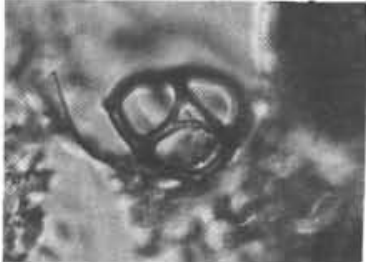

11

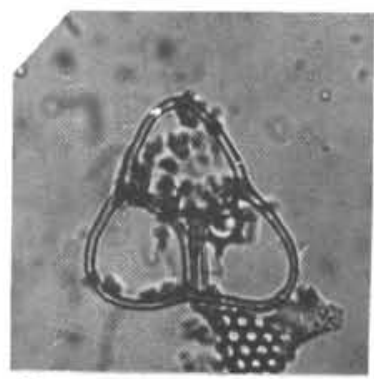

15

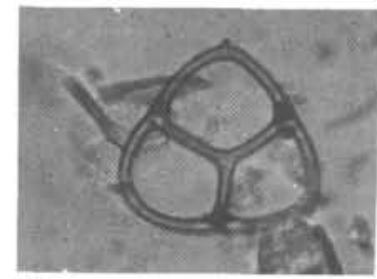

12

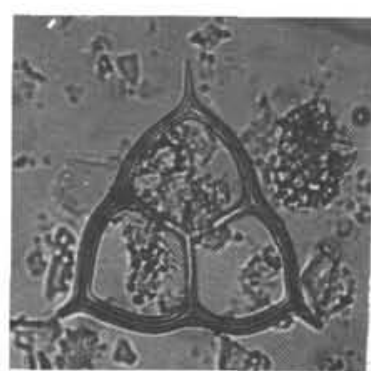

16

Plate 1. (All specimens $\times 600$.) 1-3. Corbisema apiculata (Lemmermann) Hanna, 1931, (1) Sample 512-16,CC, (2) Sample 512-12,CC, (3) Sample 512-17,CC. 4-6 Corbisema bimucronata Deflandre, 1950, (4) Sample 512-11-3, 48-40 cm, (5) Sample 512-11-2, 56-58 cm, (6) Sample 512-9-3, 60-62 cm. 7, 9. Corbisema flexuosa (Stradner) Perch-Nielsen, 1975, (7) Sample 511-6-1, 19-21 cm, (9) Sample 511-2-2, 100-101 cm. 8. Corbisema disymmetrica angulata Bukry, 1976b, Sample 512-14,CC. 10-12. Corbisema geometrica Hanna, 1928, (10) Sample Sample 511-3-3, 65-66 cm, (14) Sample 513A-33-3, 132-134 cm, (15) Sample 511-4,CC, (16) Sample 512-11-1, 74-76 cm. Bukry, 1976b, (13) 


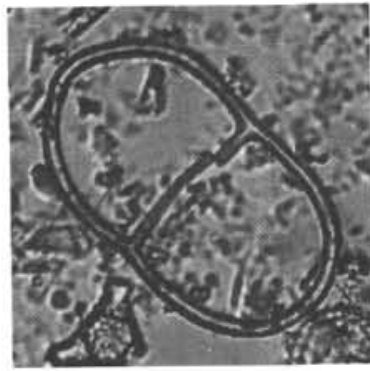

1

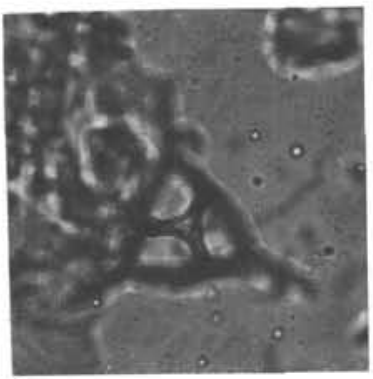

6

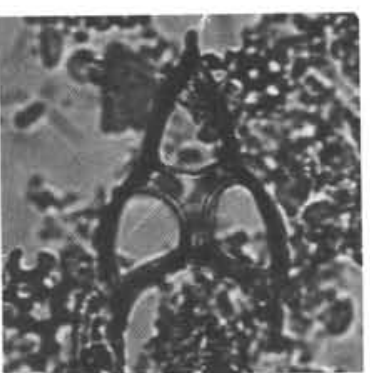

2

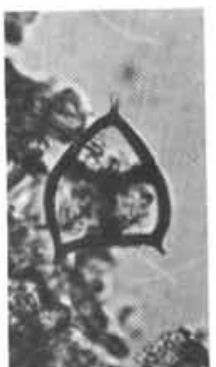

3

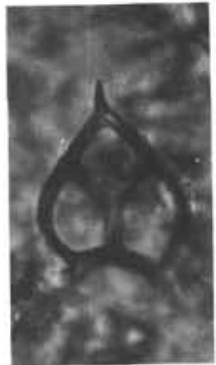

4

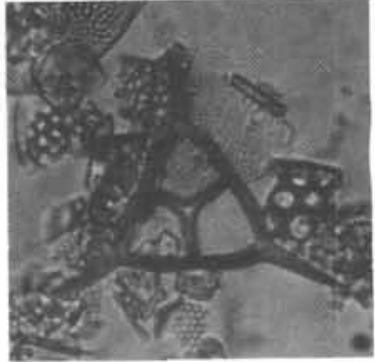

5

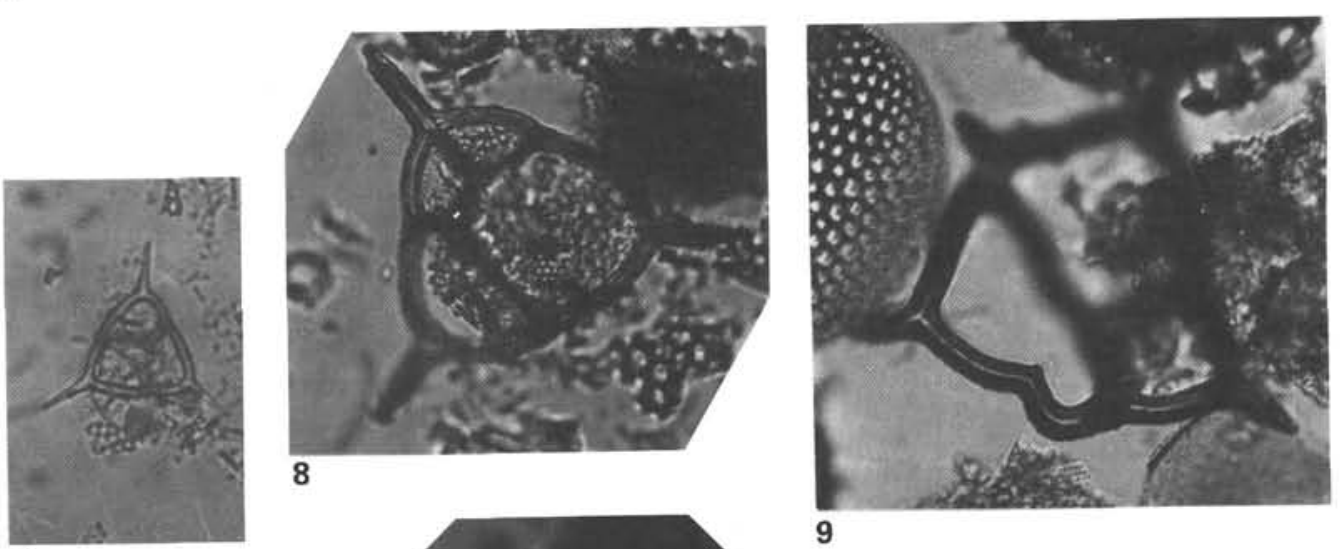

7
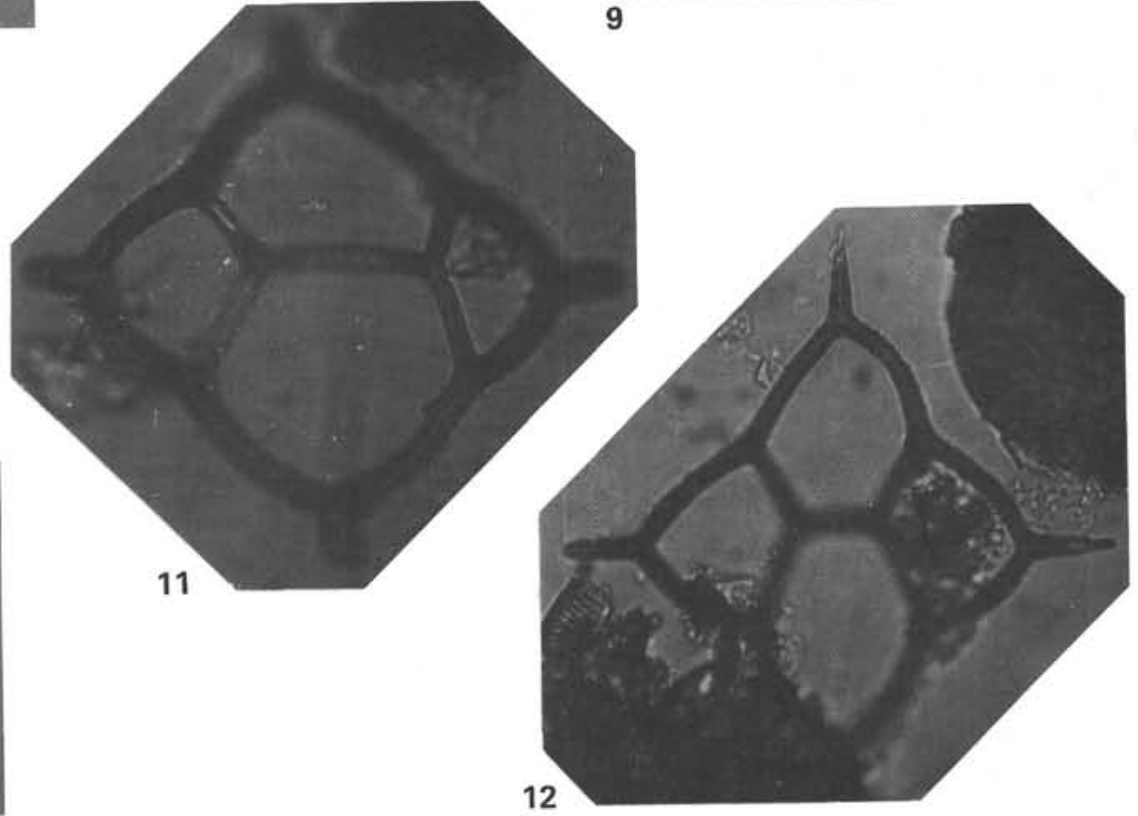

10

Plate 2. (All specimens $\times 600$.) 1. Corbisema disymmetrica communis Bukry, 1976b, Sample 512-12-1, 54-56 cm. 2-4. Corbisema hastata hastata (Lemmermann) Bukry, 1975b, (2) Sample 511-11-1, 29-30 cm, (3) Sample 511-2-2, 100-101 cm, (4) Sample 512-16-2, 15-17 cm. 5-7. Cortata (Lemmermann) Bukry, 1975a (Ehrenberg) Hanna, 1931, (5) Sample 511-6-3, 20-22 cm, (6) Sample 511-5-1, 5-7 cm, (7) Sample 511-6-4, 20-22 cm. 8-9. Corbisema 1975, (10) Sample 512-12,CC, (11) Sample 512-14,CC, (12) Sample 512-14,CC. 


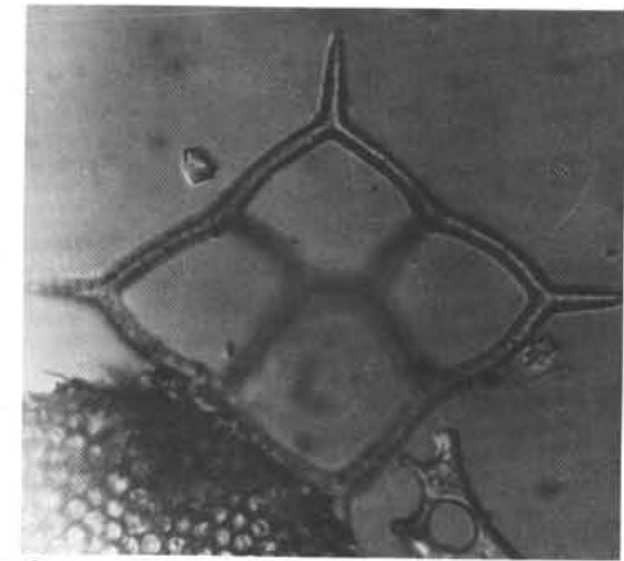

1

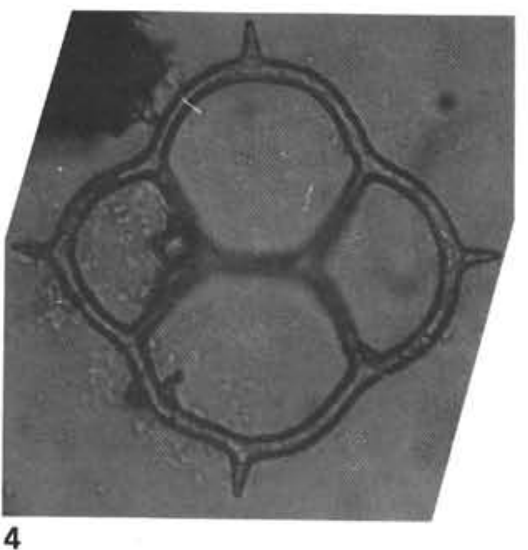

4

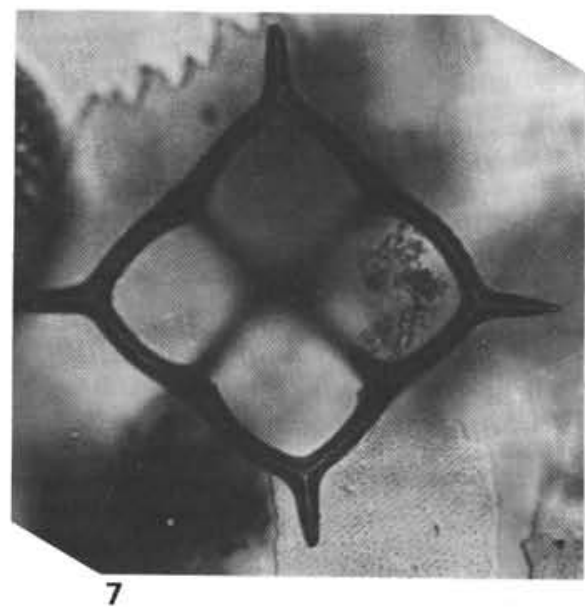

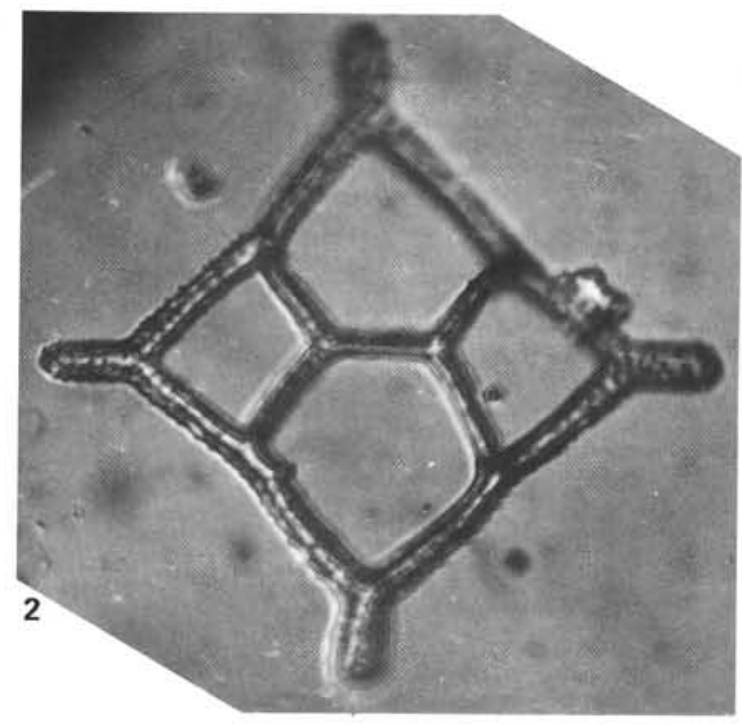
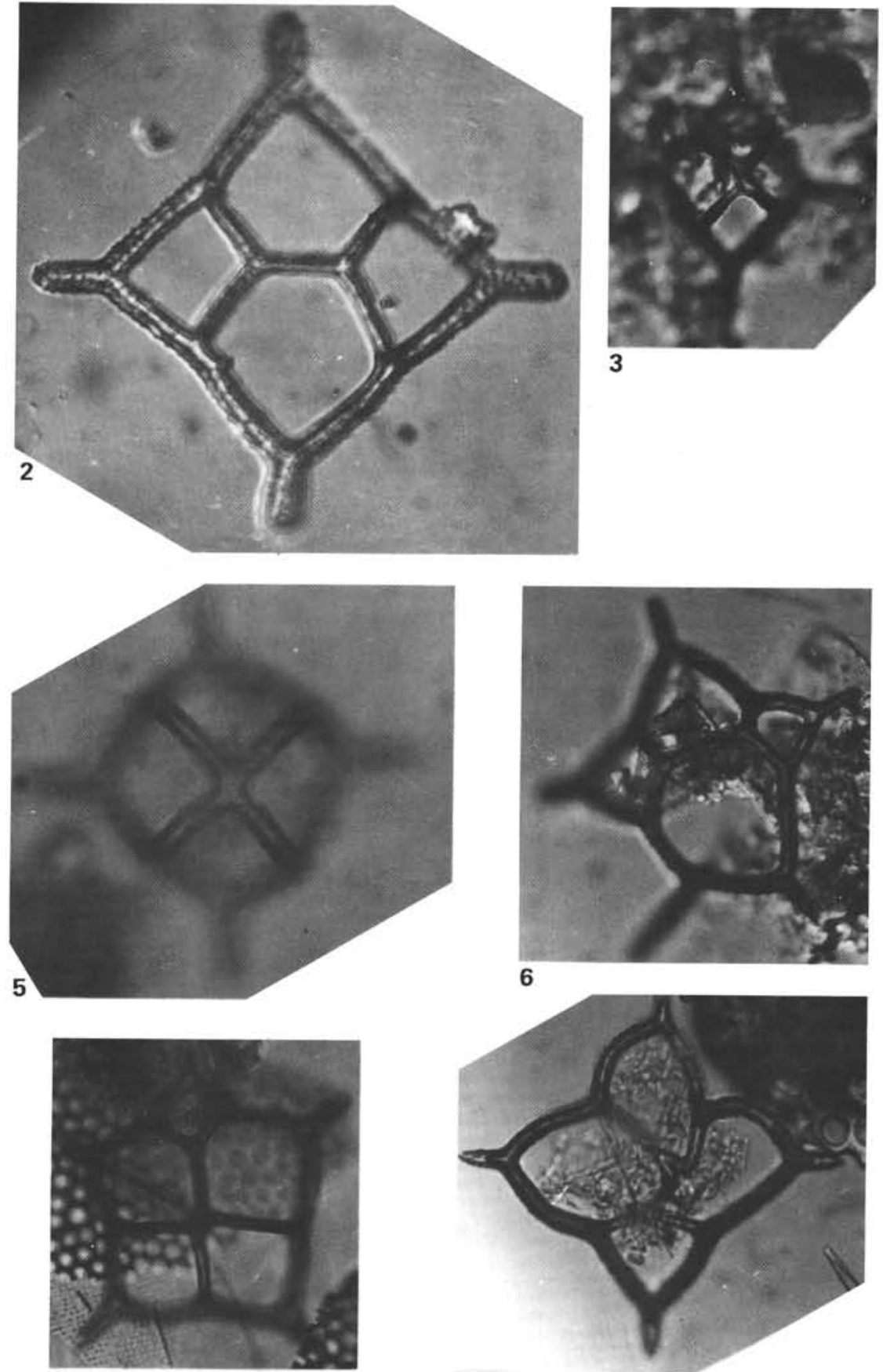

8
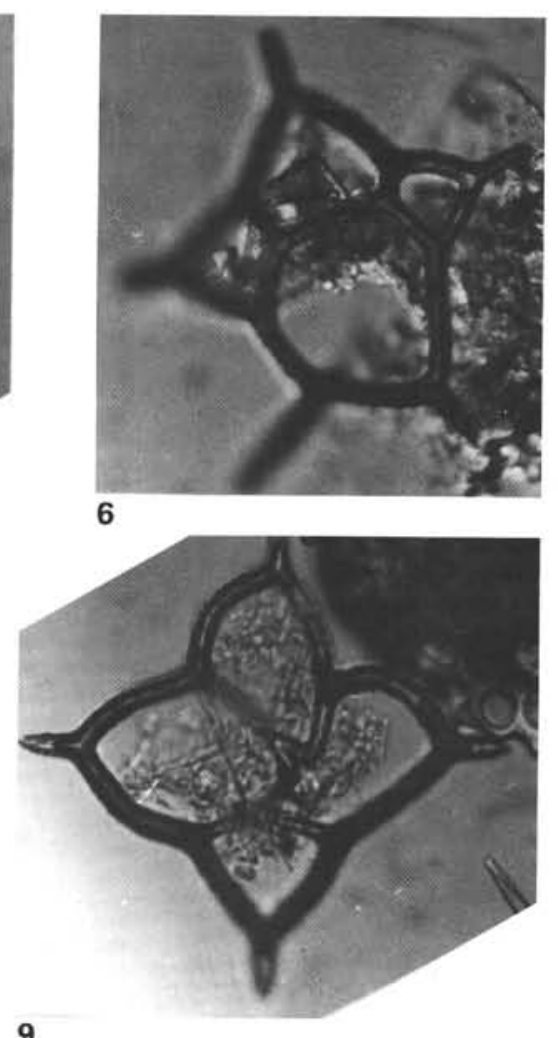

9

Plate 3. (All specimens $\times 600$.) 1-2, 4. Dictyocha aspera aspera (Lemmermann) Perch-Nielsen, 1975, (1) Sample 512-8,CC, (2) Sample 512-7,CC,

(4) Sample 512-15,CC. 3, 5, 7-8. Dictyocha sp., (3) Sample 512-9-1, 92-94 cm, (5) Sample 512-15, CC, (7-8) Sample 512-12, CC. 6, 9. Dictyocha aspera aspera (aberrant forms), (6) Sample 512-13,CC, (9) Sample 512-17,CC. 


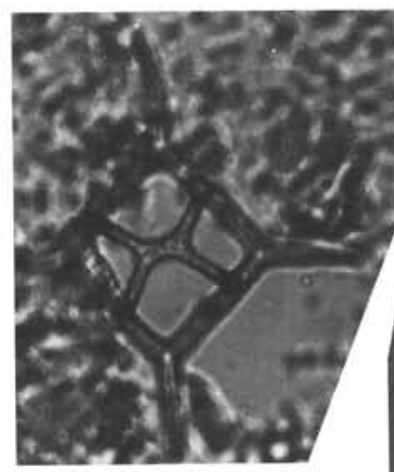

1

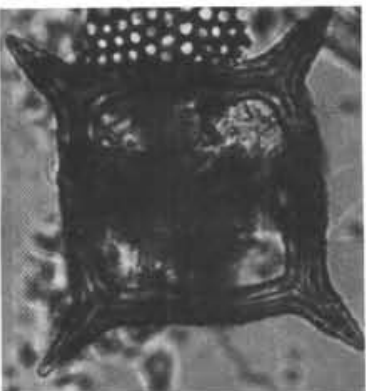

$5 a$

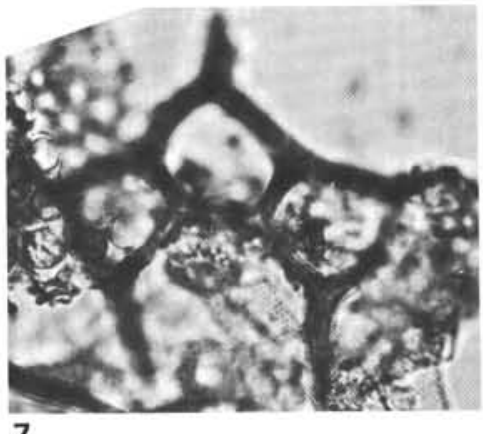

7

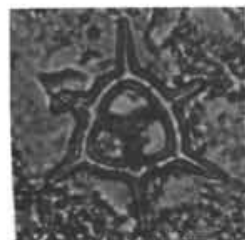

8

$5 b$
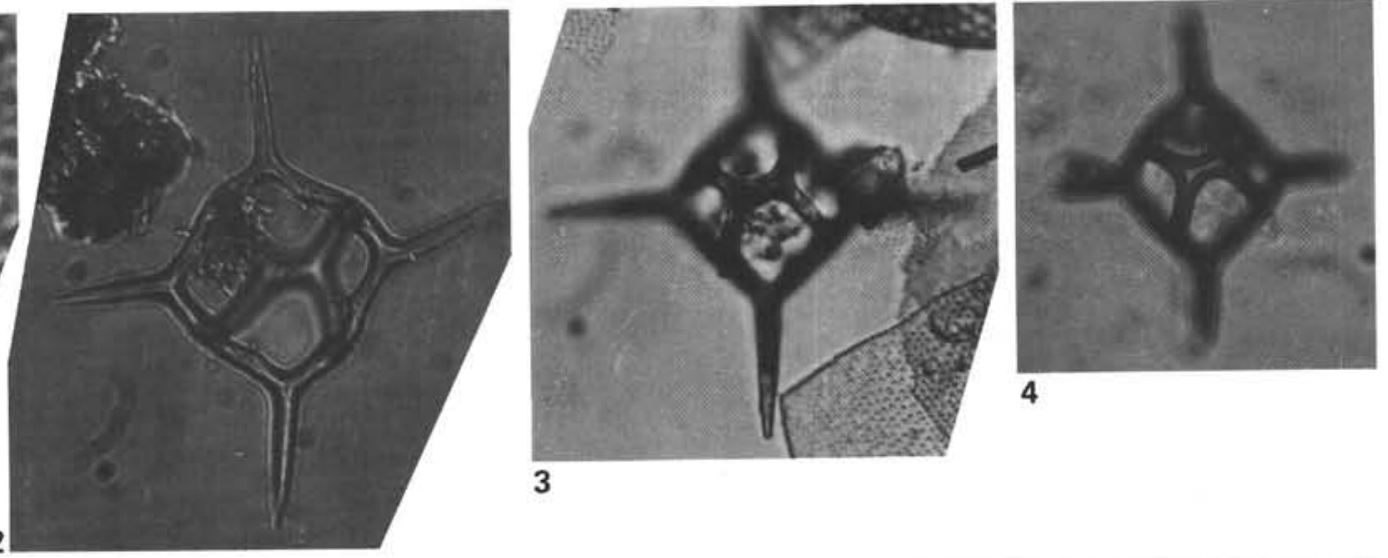

3
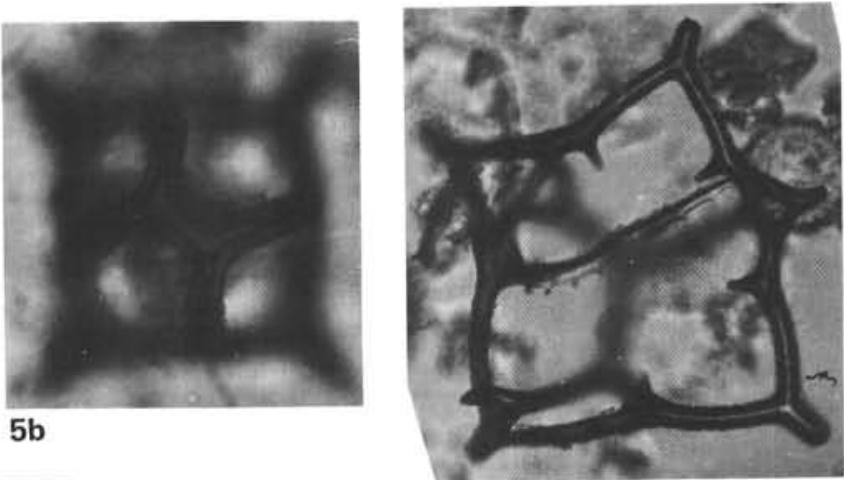

$6 a$

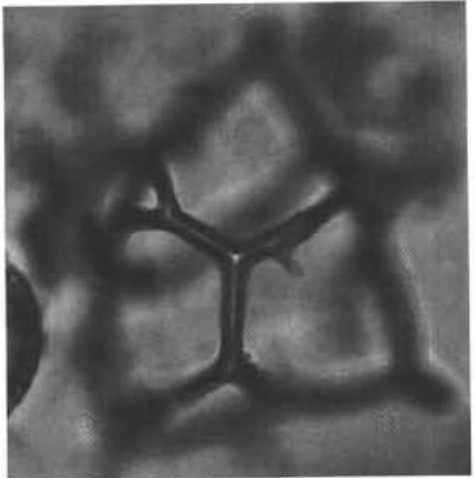

6b
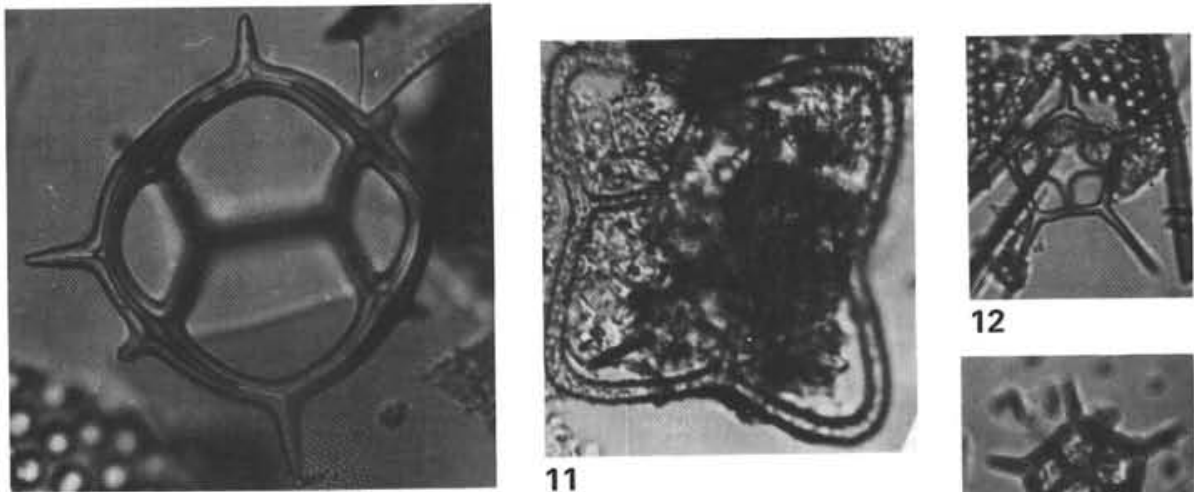

12

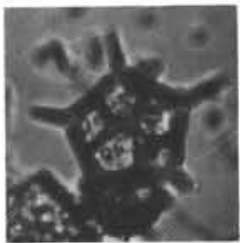

13

Plate 4. (All specimens $\times 600$.) 1-4. Dictyocha fibula Ehrenberg, 1839, (1) Sample 512-6-1, 78-80 cm, (2) Sample 512-15,CC, (3) Sample 512$12, \mathrm{CC}$, (4) Sample 512-10,CC. 5. Dictyocha cf. D. fibula, Sample 512A-2-3, 93-94 cm. (a, basal focus; b, apical focus). 6-7, 10-11. Dictyocha aberrant forms, (6) Sample 512-13-2, 54-56 cm (a, basal focus; b, apical focus), (7) Sample 512-9-3, 60-62 cm, incomplete basal apparatus, (10) Sample 512-17,CC, (11) Sample 512-14,CC. 8-9. Dictyocha hexacantha Schulz, 1928 (8) Sample 512-6-1, 78-80 cm, (9) Sample 512-6-2, 3-5 cm. 12-13. Dictyocha pentagona (Schulz) Ciesielski, 1975 (12) Sample 511-3-2, 65-66 cm with apical plate, (13) Sample 511-6-2, 20-22 cm with apical rods. 


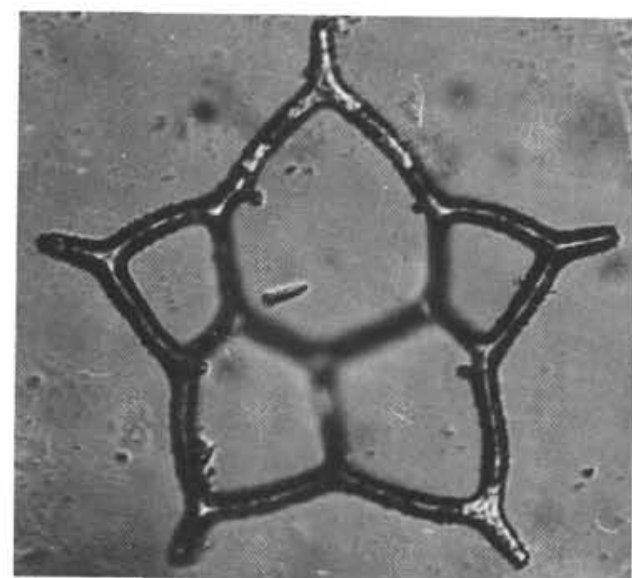

1

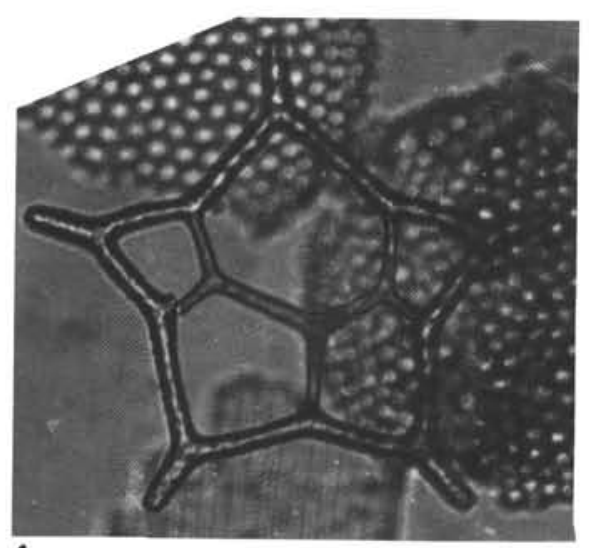

4

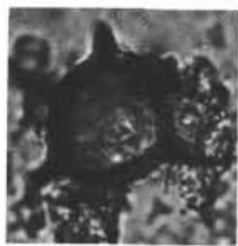

$7 a$

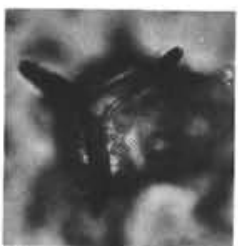

7b

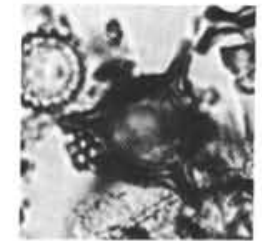

$8 a$

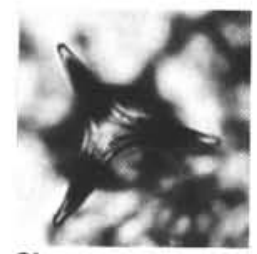

$8 b$
9

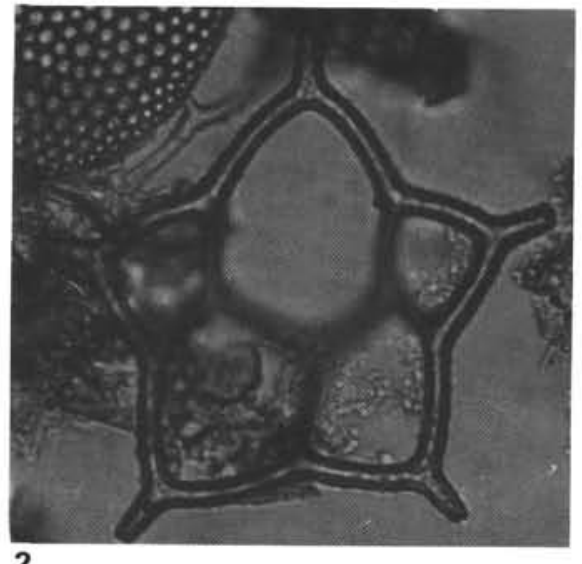

2

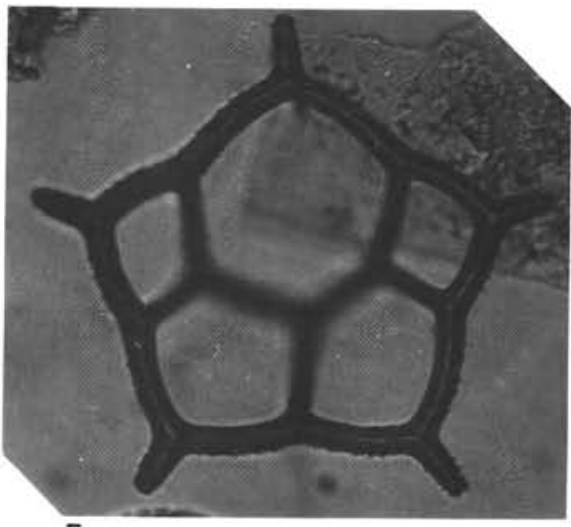

5

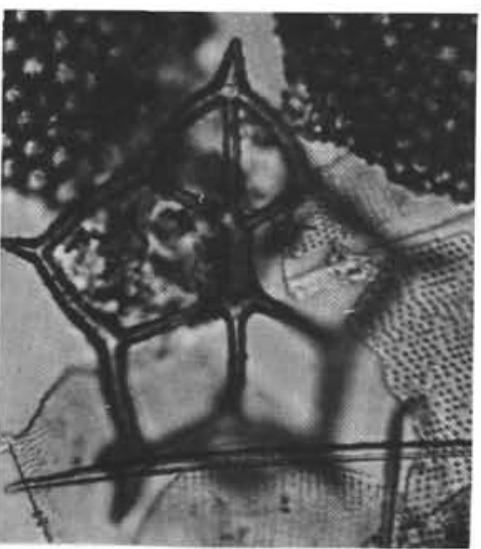

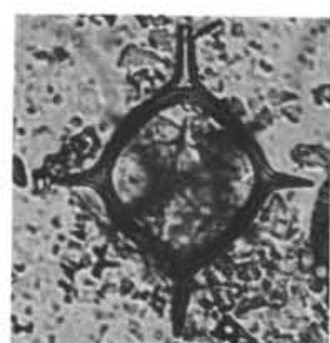

3a

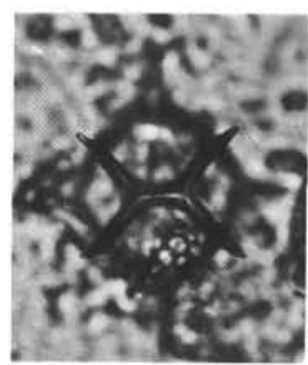

3b

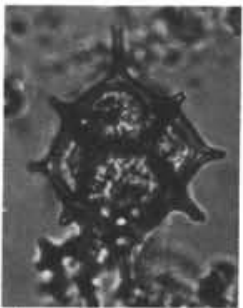

6

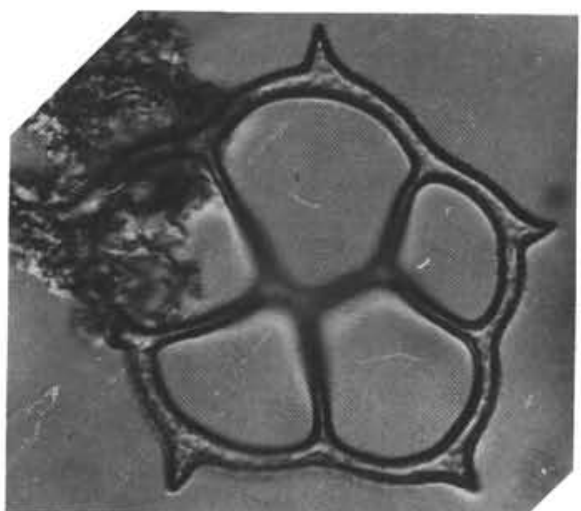

Plate 5. (All specimens $\times 600$.) 1-2, 4-5, 9-10. Dictyocha challengeri Martini and Müller, 1976, (1) Sample 512-7,CC, basal focus (note ridge and boss micro-ornamentation), (2) Sample 512-15,CC, basal focus, (4) Sample 512-7,CC, intermediate focus, (5) Sample 512-15,CC, basal focus, (9) Sample 512-12,CC, aberrant form, (10) Sample 512-13,CC, basal focus. 3, 6. Dictyocha aspera martinii Bukry, 1975b, (3) Sample 511-3-3, 65-66 cm (a, basal focus; b, apical focus), (7) Sample 512A-2-4, 93-94 cm. 7-8. Dictyocha spinosa (Deflandre) Glezer, 1966, (7) Sample $512-11-1,74-76 \mathrm{~cm}$ (a, basal focus; b, apical focus), (8) Sample 512-9-3, 60-62 cm (a, basal focus; b, apical focus). 


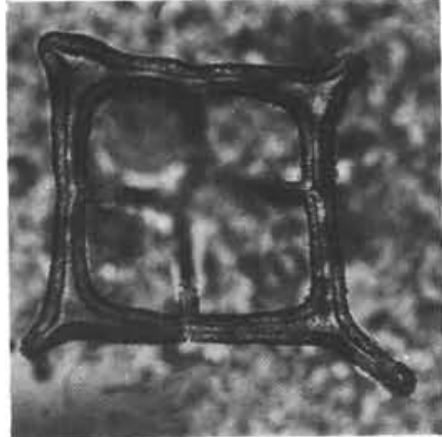

1

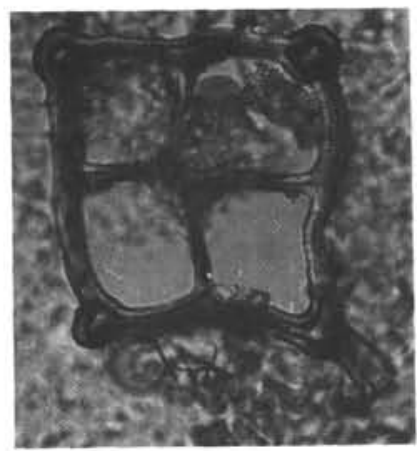

4

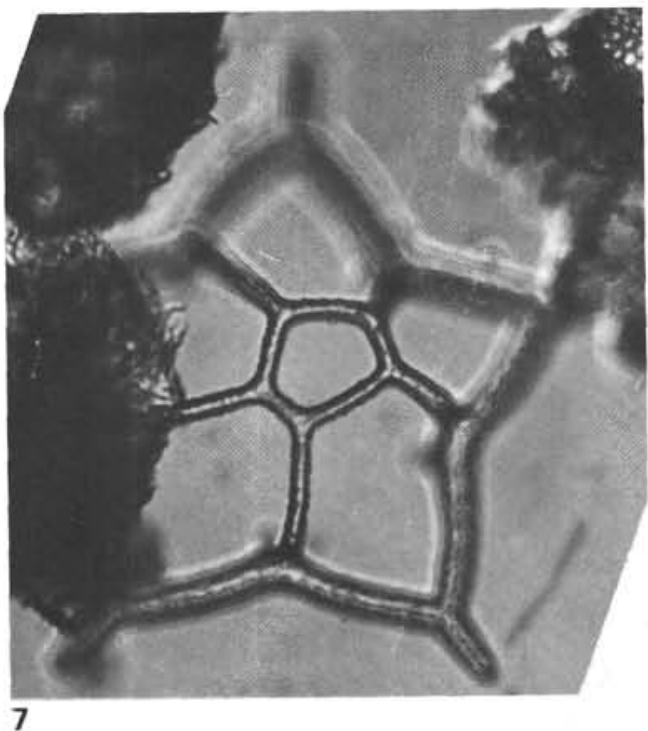

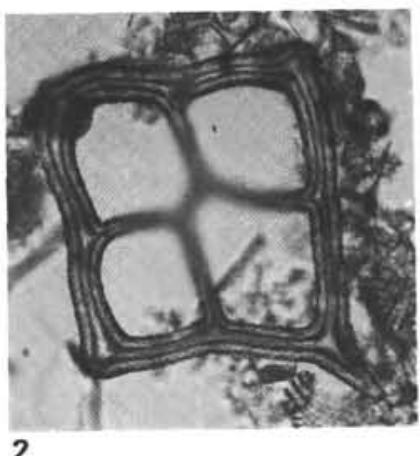

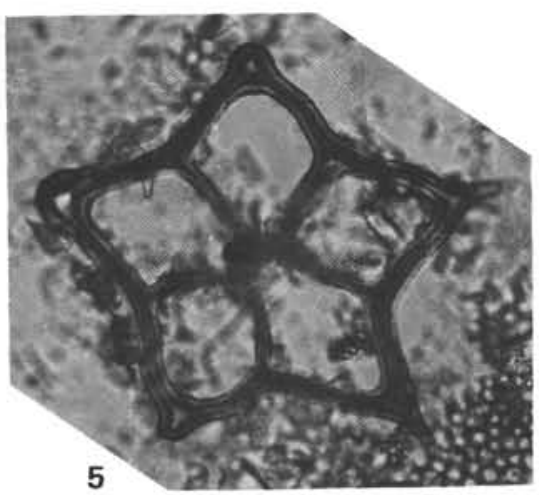

5

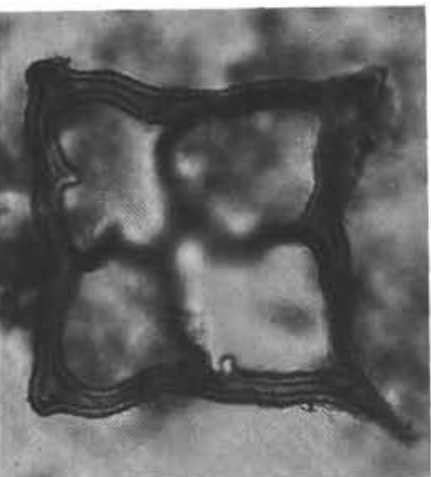

3

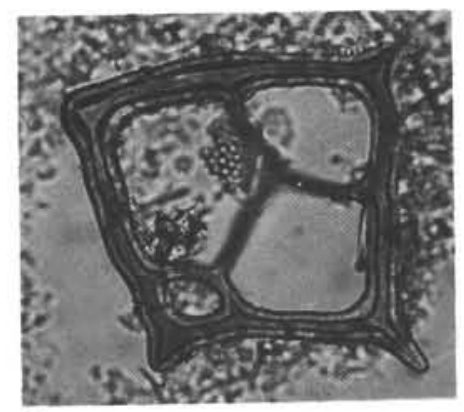

6

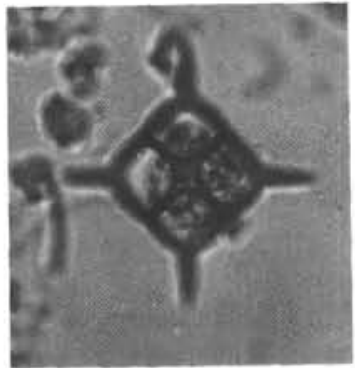

8

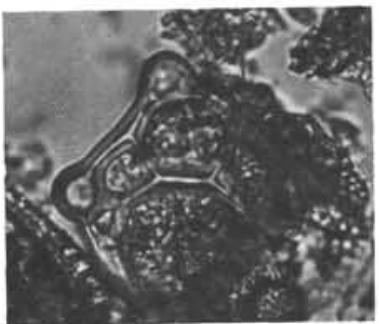

9a

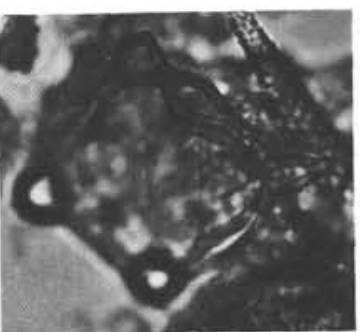

$9 b$

Plate 6. (Figs. 1-6 ×250; Figs. 7-9 ×450.) 1-6. Dictyocha stelliformis n.sp. (1) Sample 512A-2-4, 93-94 cm, paratype, with conspicuous tubelike basal apparatus and thickenings of basal ring at junctures with basal spines, (2) Sample 512-17-1, 28-30 cm, paratype, (3) Sample 512-17-3, 4-6 cm, irregular apical bars, (4) Sample 512-18-1, 37-39 cm, holotype, with bulbous nodules on three corners, (5) Sample 512-18-1, 37-39 cm, paratype, five-sided form with three bulbous corners on basal apparatus, (6) Sample 512A-2-3, 93-94 cm, atypical form. 7. Dictyocha challengeri Martini and Müller, 1976, Sample 512-8,CC, with pustulate micro-ornamentation. 8. Dictyocha deflandrei Frenguelli ex Glezer, 1966, Sample 511-1-4, 15-16 cm. 9. Dictyocha cf. D. stelliformis, Sample 511-12-1, 8-10 cm (a, low focus; b, high focus). 


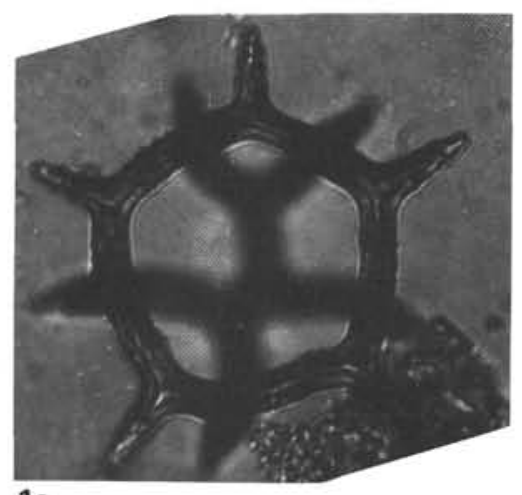

1a

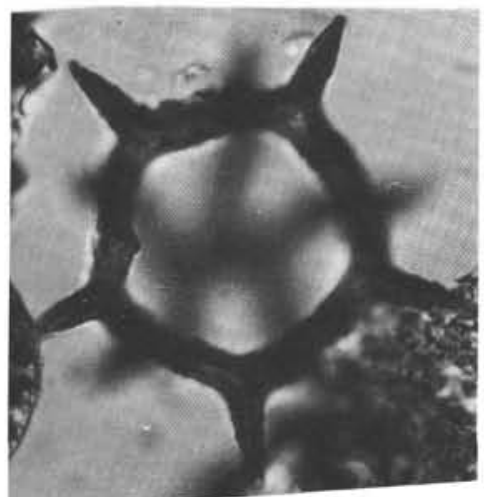

3a

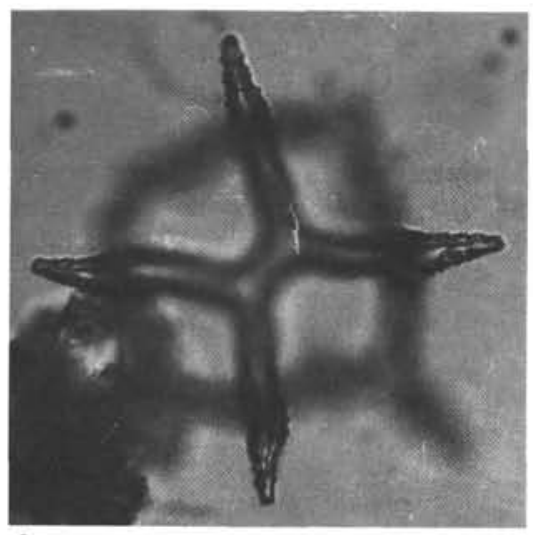

4

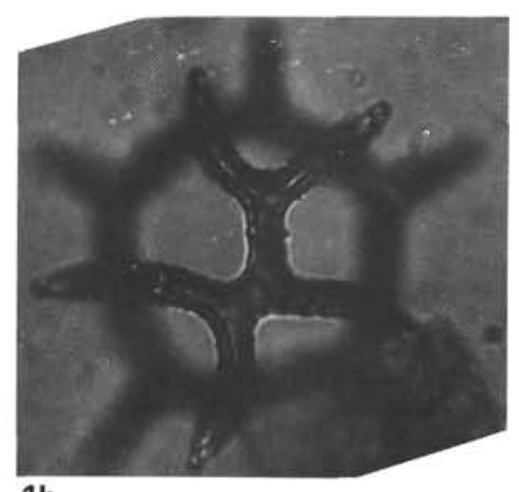

1b

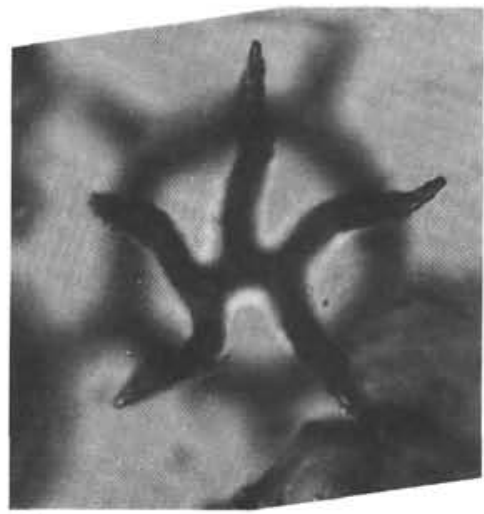

3b
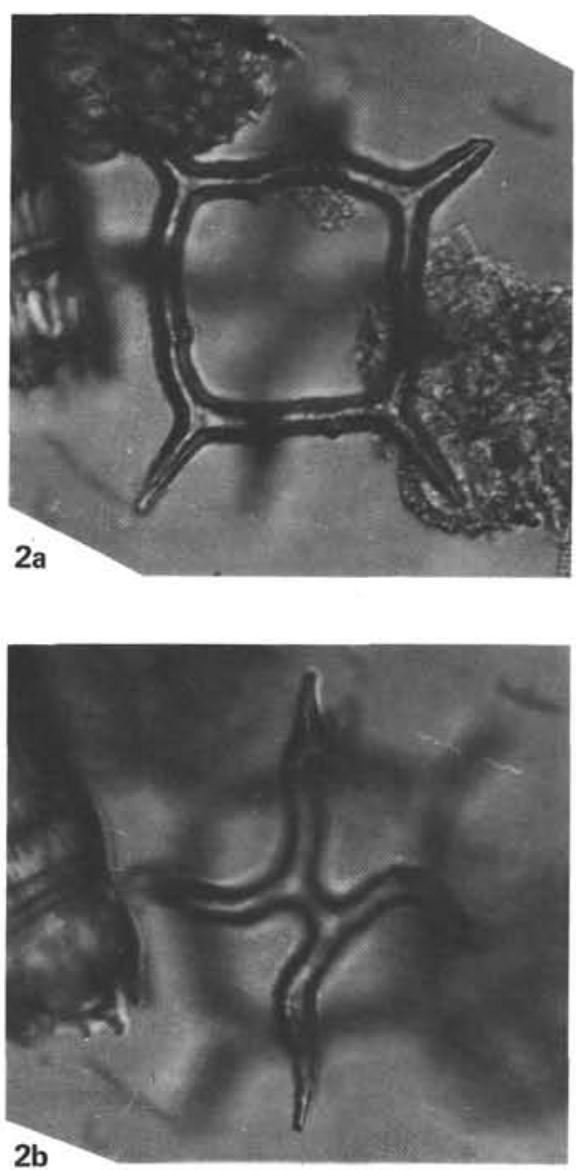

$2 b$

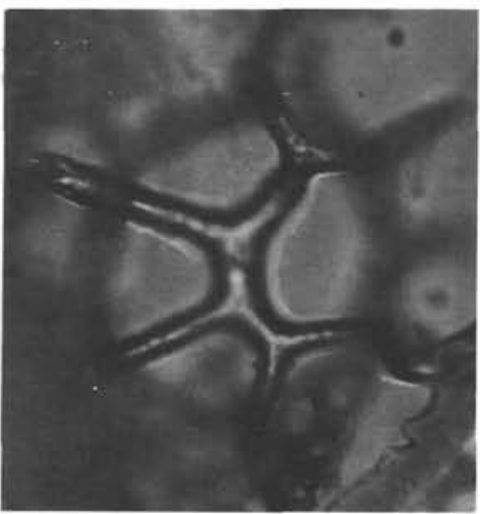

$5 b$

Plate 7. (All specimens $\times 600$.) 1-5. Dictyocha anguinea n.sp. (1) Sample 512-18,CC, paratype, five-sided form (a, basal focus; b, apical focus), (2) Sample 512-19,CC, paratype, four-sided form (a, basal focus; b, apical focus), (3) Sample 512-18, CC, holotype, five-sided form (a, basal focus; b, apical focus), (4) Sample 512-19,CC, four-sided form, apical focus, (5) Sample 512-18,CC, paratype, six-sided form (a, basal focus; b, apical focus). 


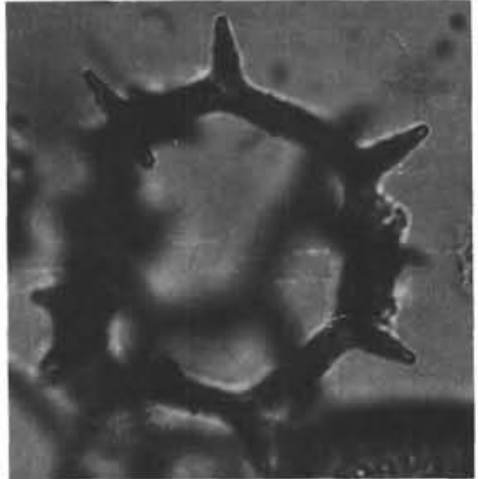

1a

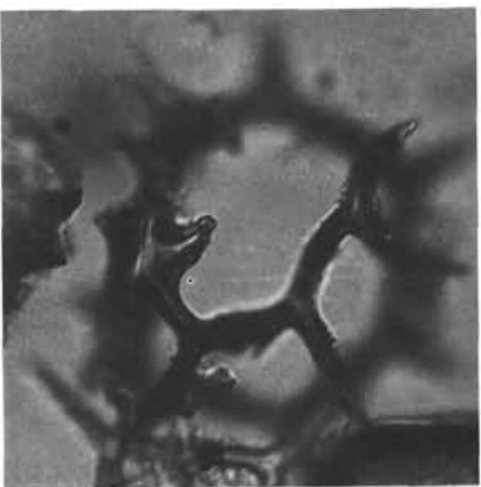

$1 b$

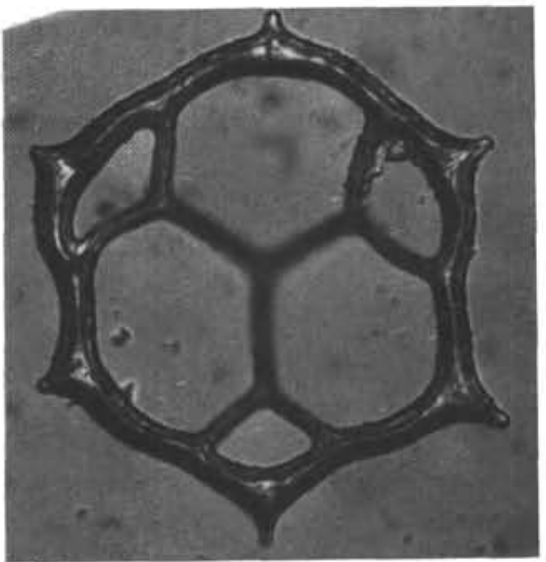

2
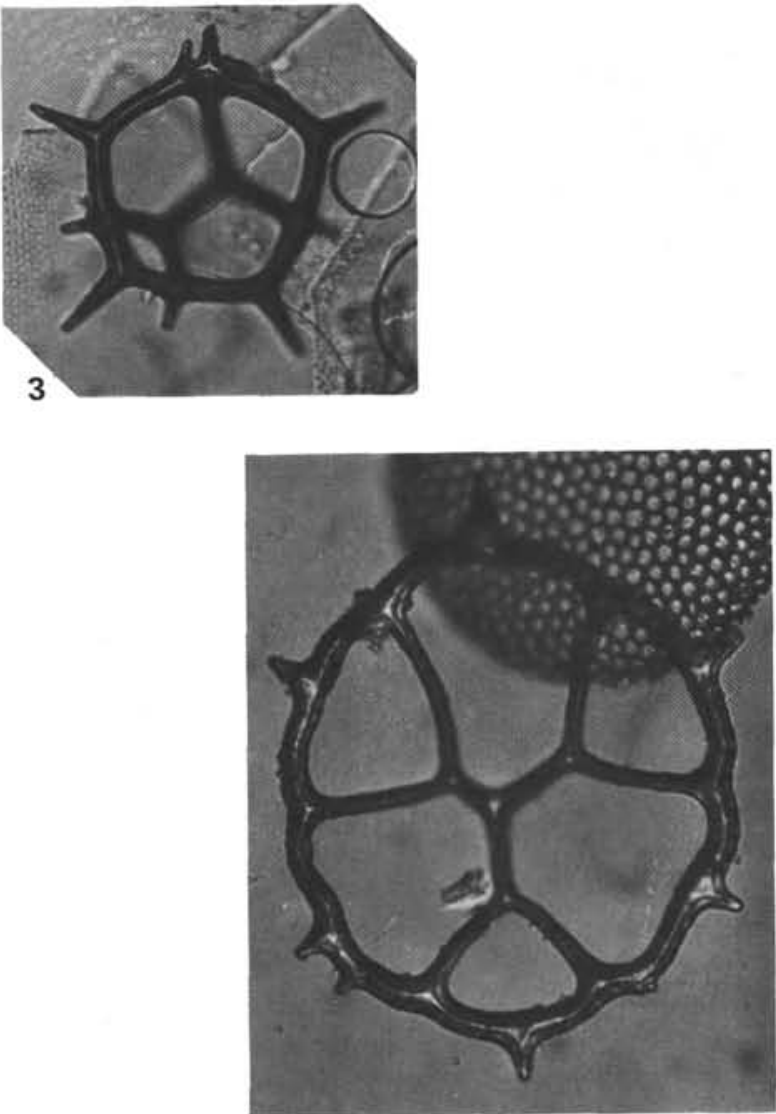

5

Plate 8, 1, 3. Dictyocha anguinea $\mathrm{n} . \mathrm{sp}, \times 600$, Sample 512-18,CC, (1) aberrant form (a, basal focus; b, apical focus). 2, 4-5. Dictyocha grandis n.sp., (2) Sample 512-7,CC, paratype, $\times 500$, (4) Sample 512-9,CC, holotype, $\times 600$, (5) Sample 512-7,CC, paratype, $\times 400$. 


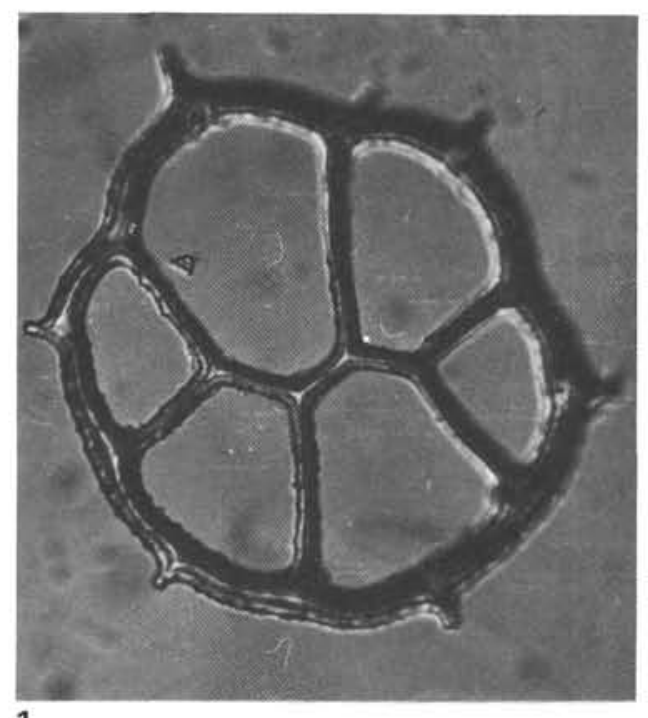

1

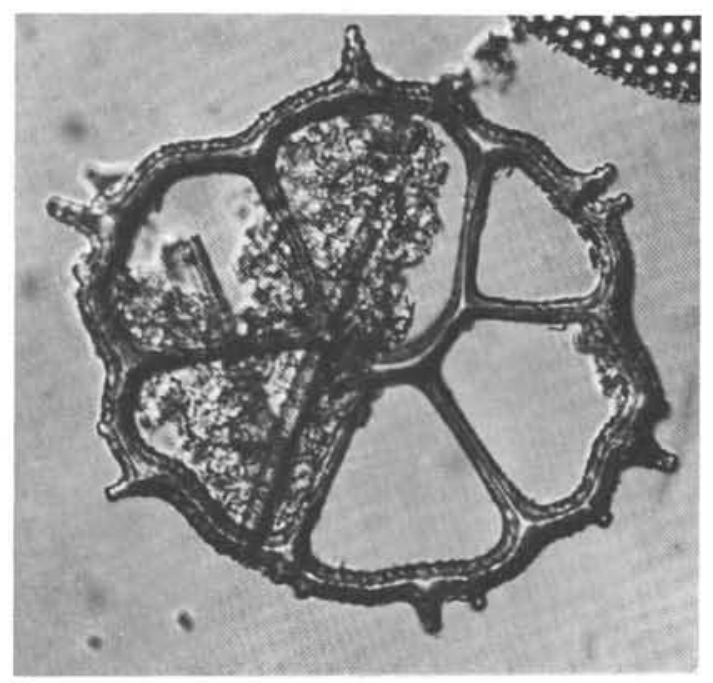

3

Plate

late 9. 1-4. Dictyocha grandis n.sp., (1-2) Sample 512-7,CC, paratypes $(1, \times 500 ; 2, \times 400),(3-4)$ Paratypes, $\times 500(3$, Sample $512-8, C C ; 4$,
Sample $512-7$, CC). 5. Distephanus antiquus Glezer, 1964 , Sample $512-9-1,92-94 \mathrm{~cm}, \times 600$ (a, basal focus; b, apical focus). 


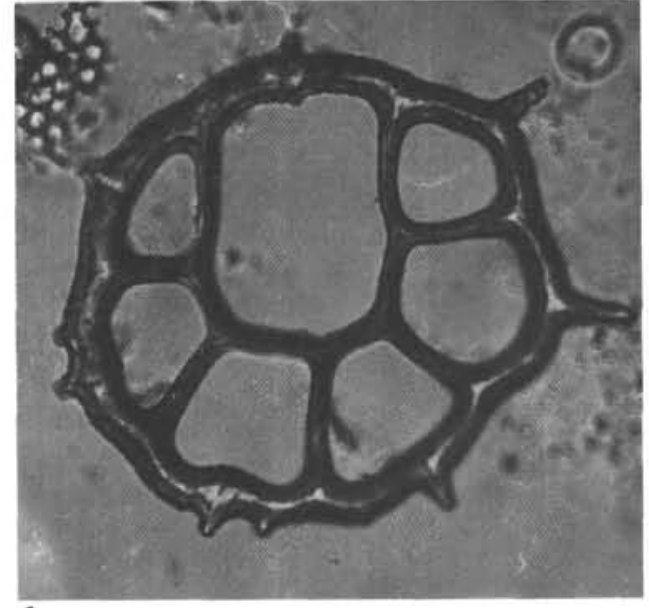

1
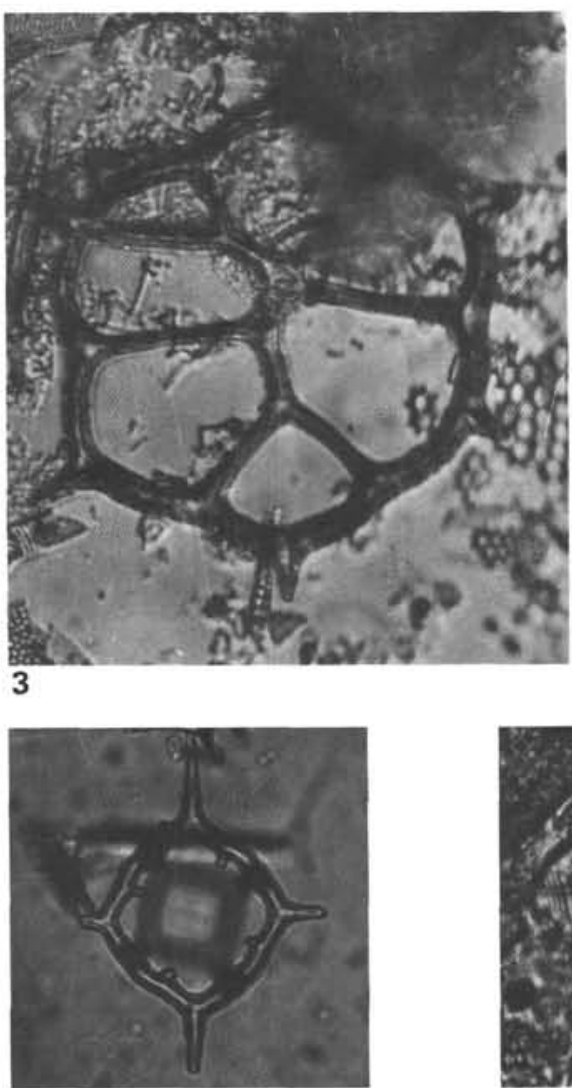

6
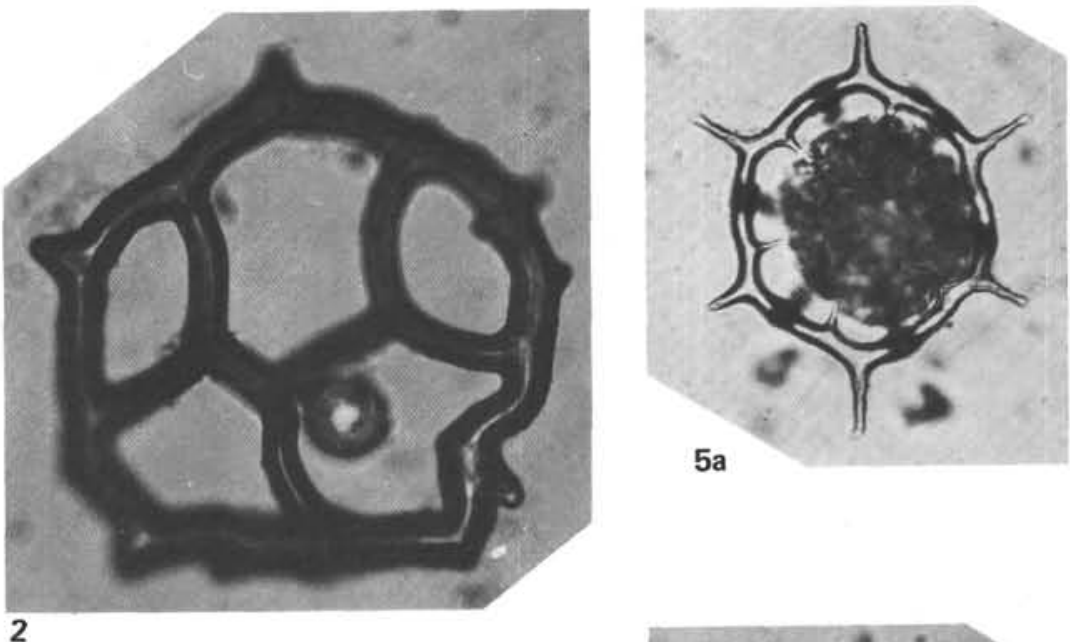

5 a
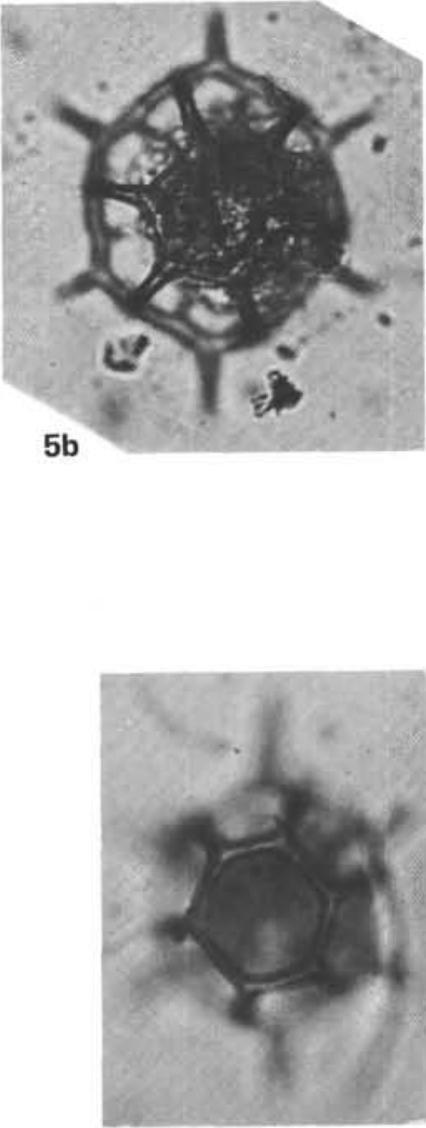

$8 b$

Plate 10. 1-4. Dictyocha grandis n.sp., (1) Sample 512-10,CC, $\times 400$, (2) Sample 512-10,CC $\times 500$, (3) Sample 512-12-2, 54-56 cm, $\times 500$, (4) Sample 512-11-2, 56-58 cm, $\times 400$. 5, 8. Distephanus boliviensis (Frenguelli) Bukry and Foster, 1973, $\times 600$, Sample 511-1-4, 15-16 cm, (5) a, basal focus; b, apical focus, (8) a, basal focus; b, apical focus. 6-7. Distephanus crux crux (Ehrenberg) Haeckel, 1887, $\times 600$, (6) Sample 5112-4, 20-21 cm, (7) Sample 511-3-2, 65-66 cm. 


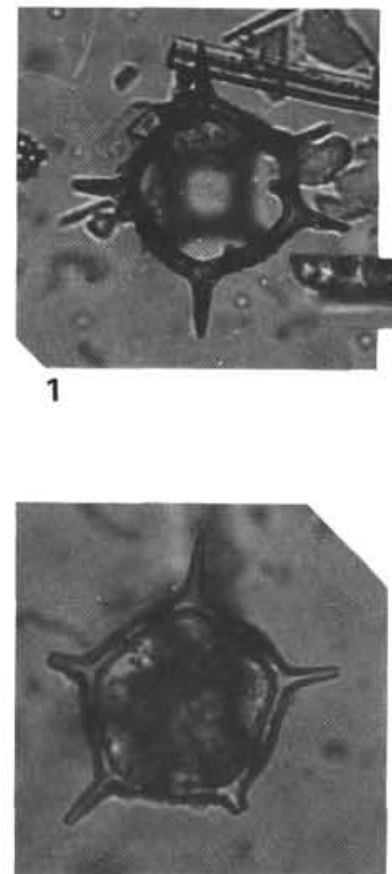

$4 a$

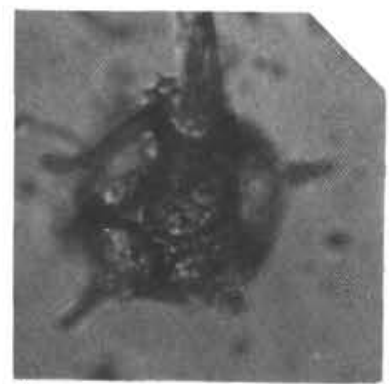

4b

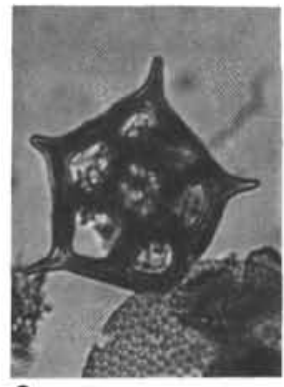

9

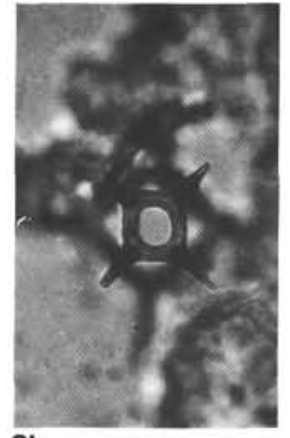

2b

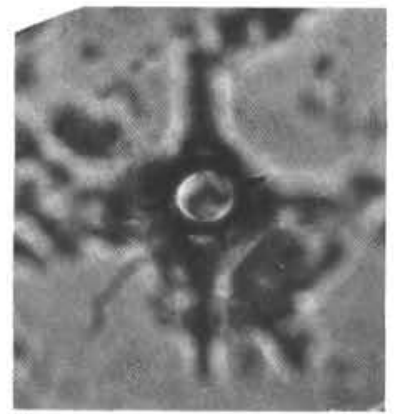

5

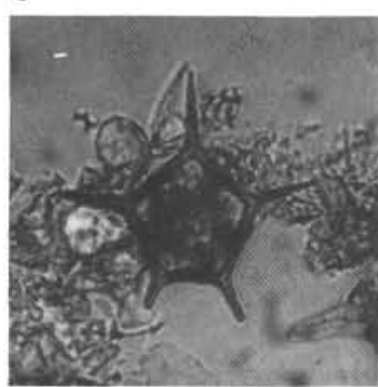

$7 \mathrm{a}$

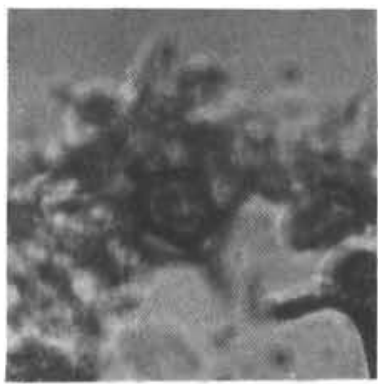

7b

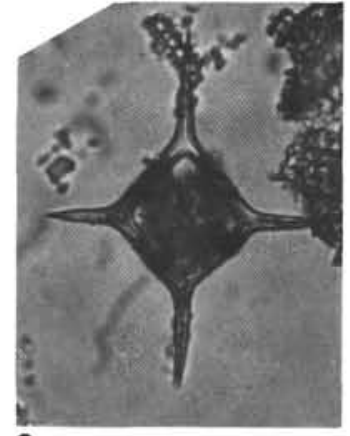

3a

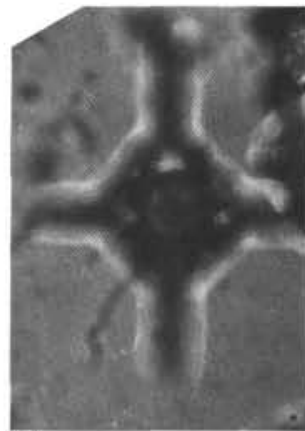

3b

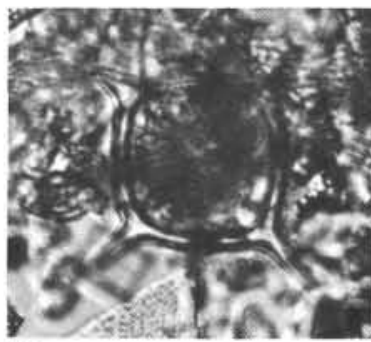

$6 a$

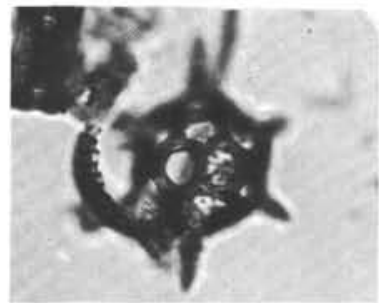

$8 a$

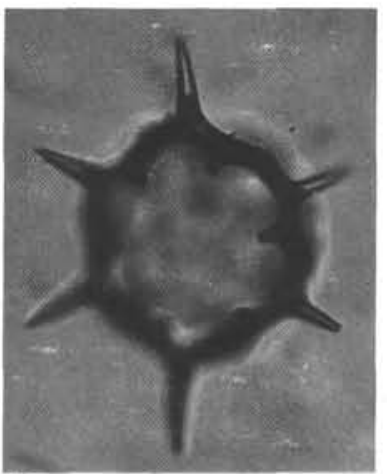

$10 \mathrm{a}$

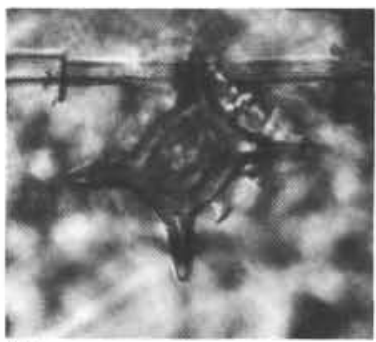

$6 b$

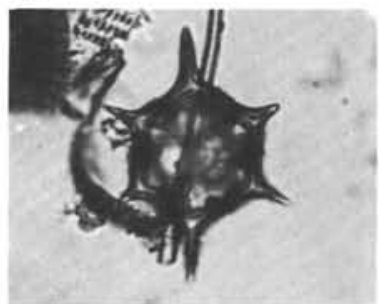

$8 b$

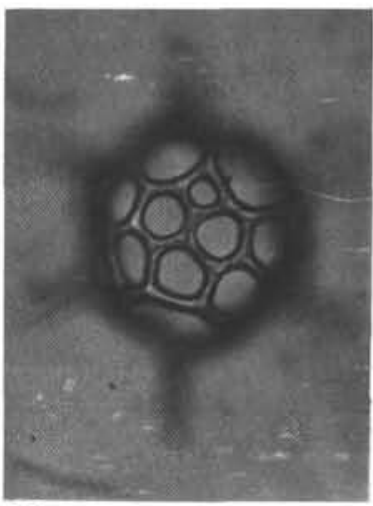

10b

Plate 11. (All specimens $\times 600$.) 1. Distephanus crux crux (Ehrenberg) Haeckel, 1887, Sample 511-4,CC. 2-3, 5-6. Distephanus crux paulii n.subsp. (2) Sample 511-17,CC, holotype, (3) Sample 511-12-2, 8-10 cm, paratype (a, basal focus; b, apical focus), (5) Sample 511-12-2, 8-10 $\mathrm{cm}$, apical focus, (6) Sample 511-16,CC, paratype (a, basal focus; b, apical focus). 4, 7, 9. Distephanus quinquangellus Bukry and Foster, 1973. (4) Sample 512-2-2, 100-101 cm (a, basal focus; b, apical focus), (7) Sample 511-2-1, 100-101 cm (a, basal focus; b, apical focus), (9) Sample 511-12-2, 8-10 cm. 8. Distephanus speculum s.1. (Ehrenberg) Haeckel, 1887, Sample 512-9-3, 60-62 cm. 10. Distephanus cf. D. speculum, Sample 512-12,CC (a, basal focus; $\mathrm{b}$, apical focus). 

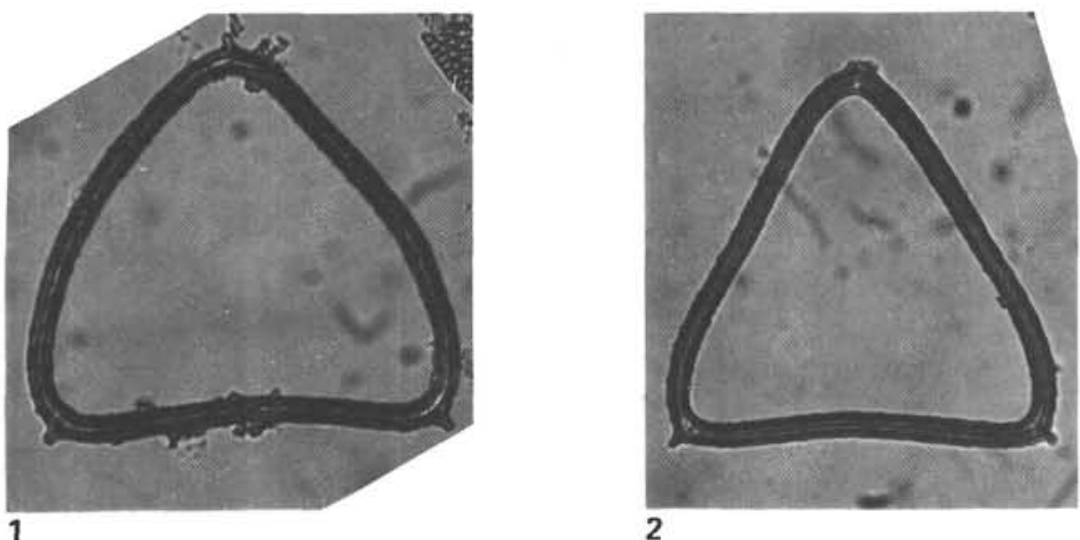

2
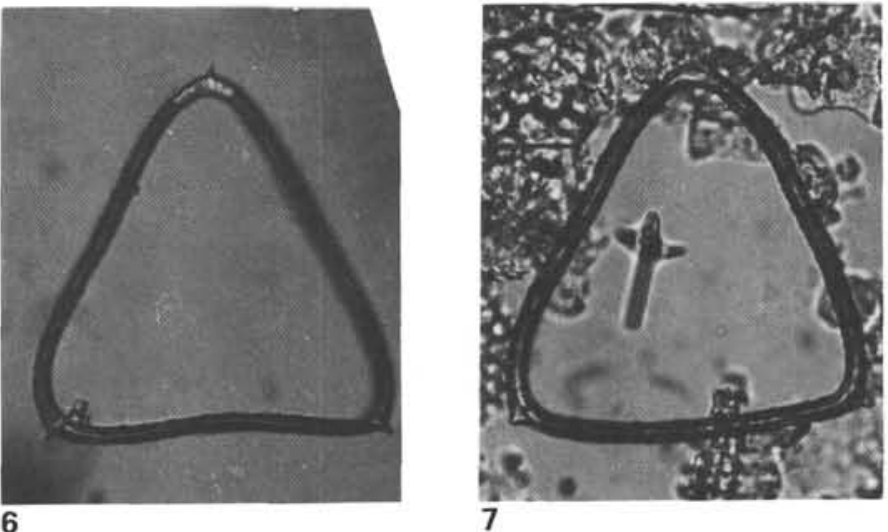

4
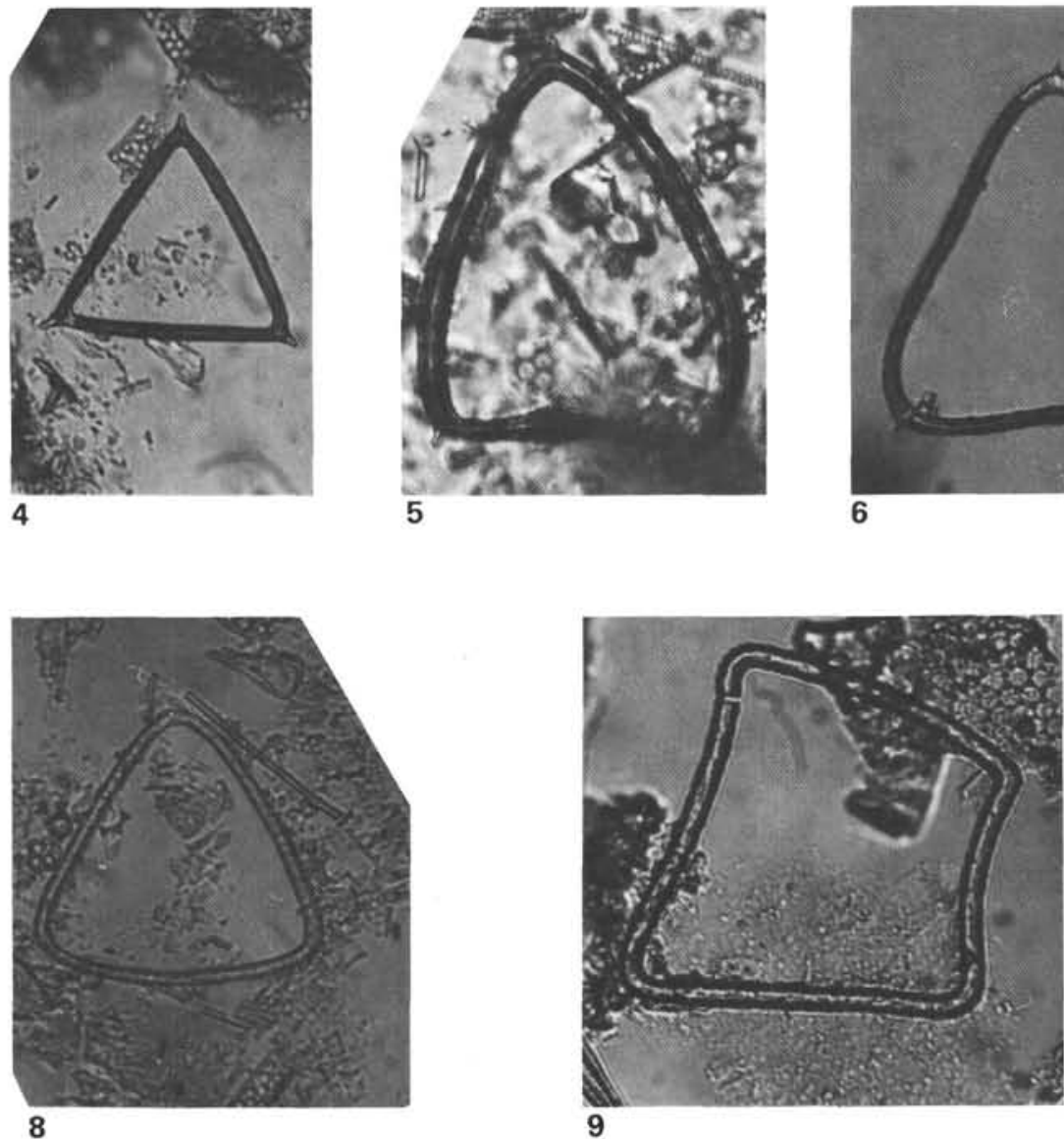

8

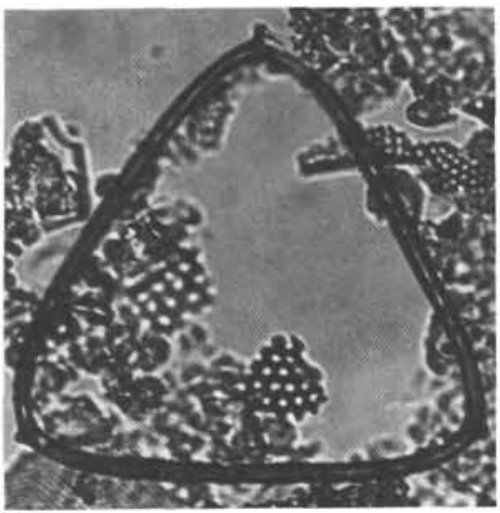

3

Plate 12. (All specimens $\times 600$.) 1-7. Mesocena apiculata (Schulz) Hanna, 1931 (1) Sample 512-6,CC, (2) Sample 512-7-3, 60-62 cm, (3) Sample 511-1-4, 15-16 cm, (4) Sample 511-6-1, 20-22 cm, (5) Sample 511-16,CC, (6) Sample 512-12,CC, (7) Sample 512-6-1, 78-80 cm. 8-10. Mesocena oamaruensis Schulz, 1928, (8) Sample 511-2-4, 20-21 cm, (9) Sample 512-18,CC, (10) Sample 512-7-3, 60-62 cm. 

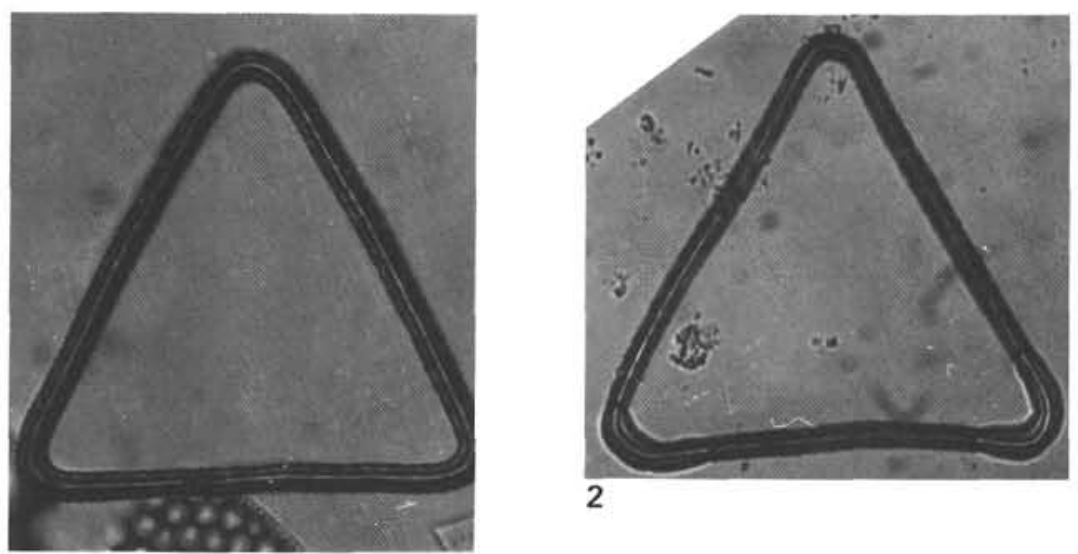

2

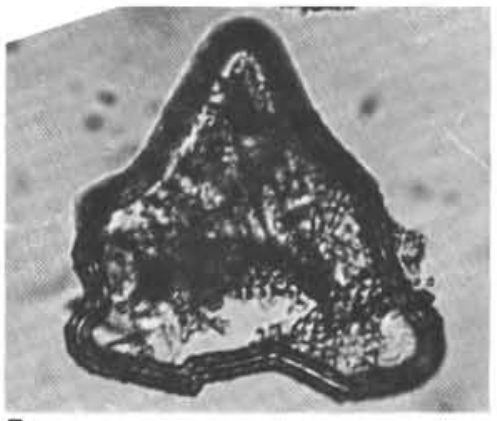

5

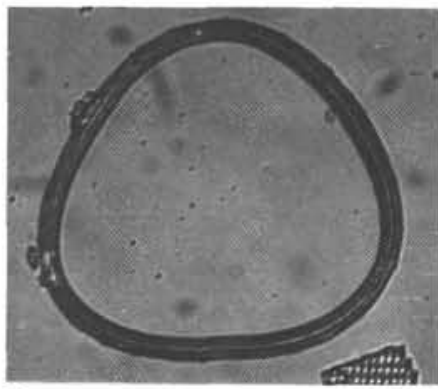

8

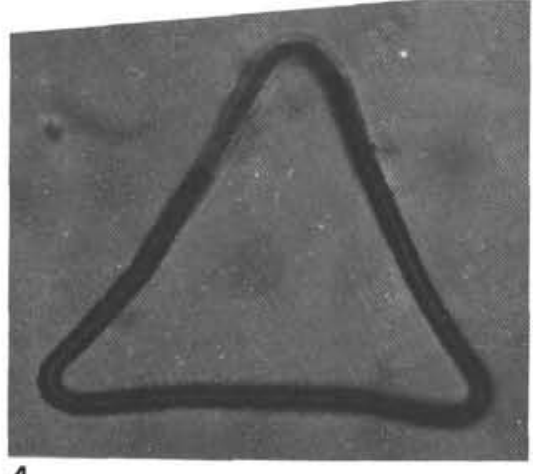

4

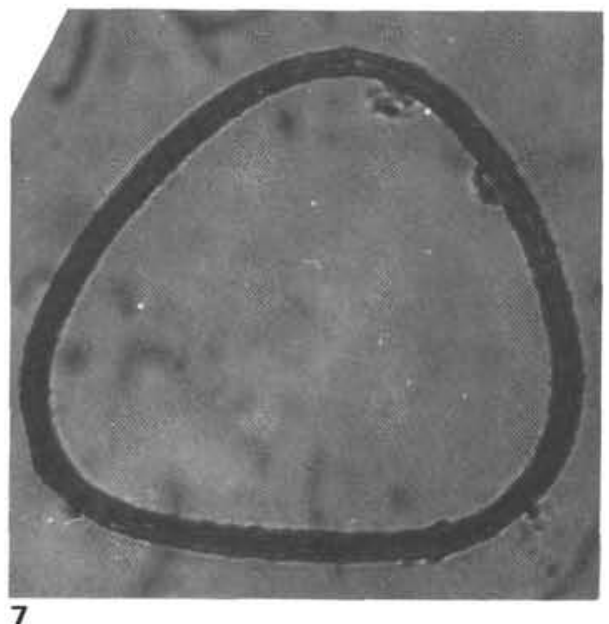

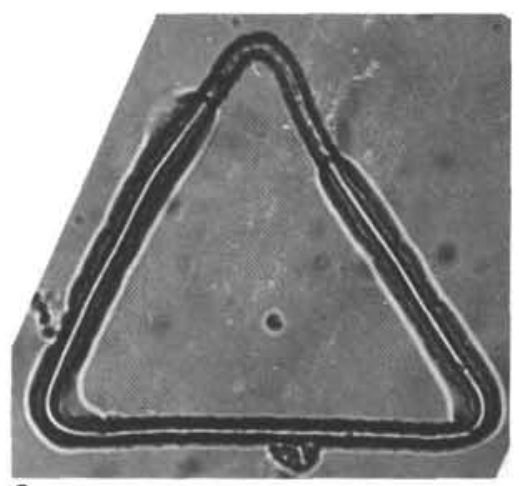

3

7

Plate 13. (All specimens $\times 600$.) 1-9. Mesocena oamaruensis Schulz, 1928 (1) Sample 512-12,CC, (2-3) Sample 512-6,CC, (4) Sample 512-12,CC, (5) Sample 512-6,CC, aberrant form, (6) Sample 512-13-1, 42-44 cm, (7) Sample 511-3,CC, (8) Sample 512-6,CC, (9) Sample 512-7-3, 60-62 cm. 

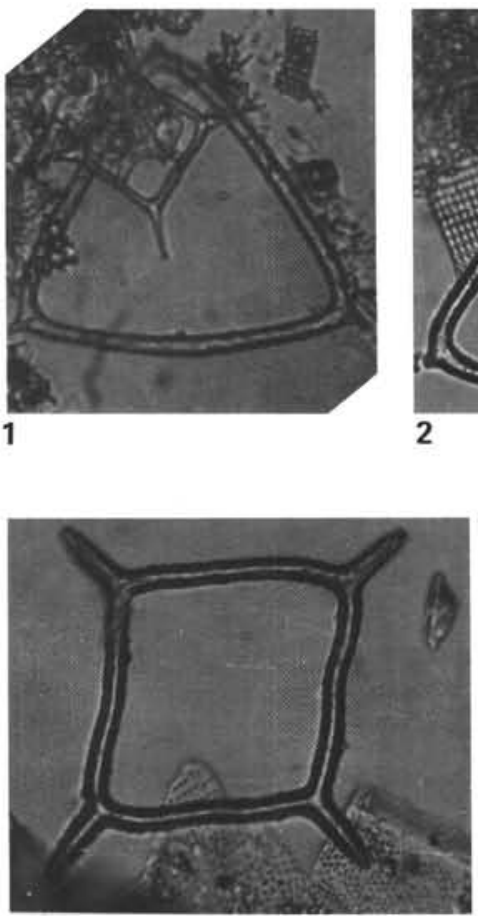

5
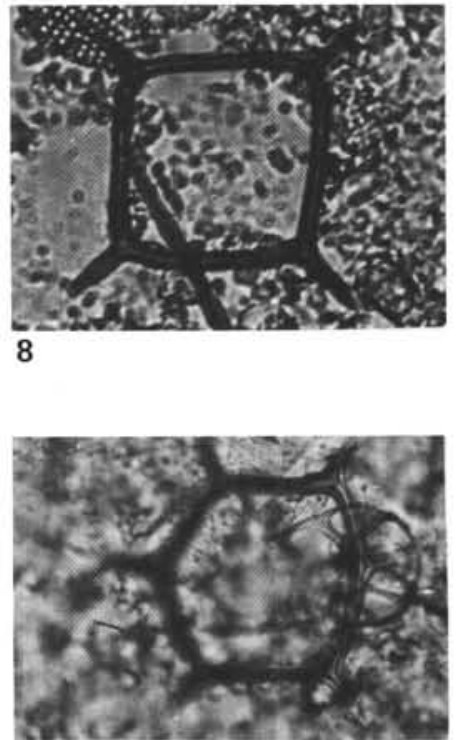

9

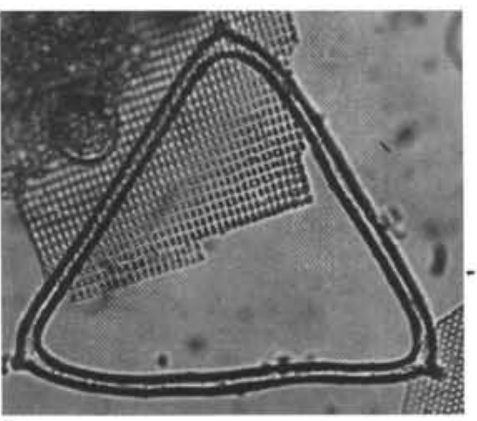

2
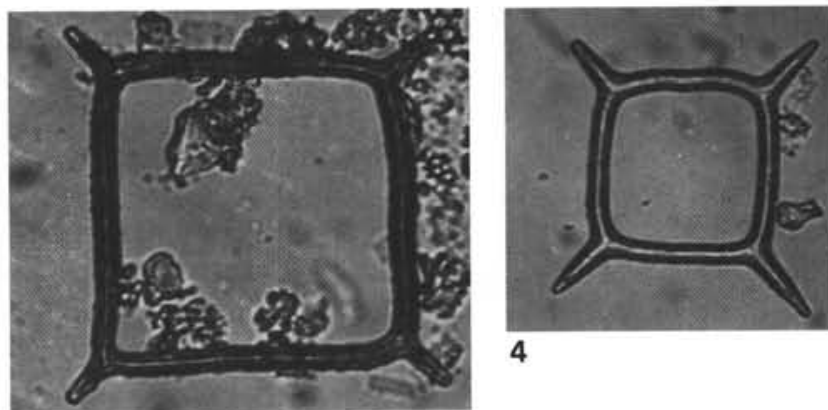

4

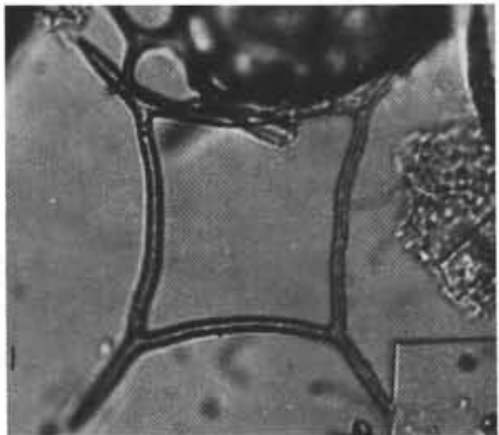

6

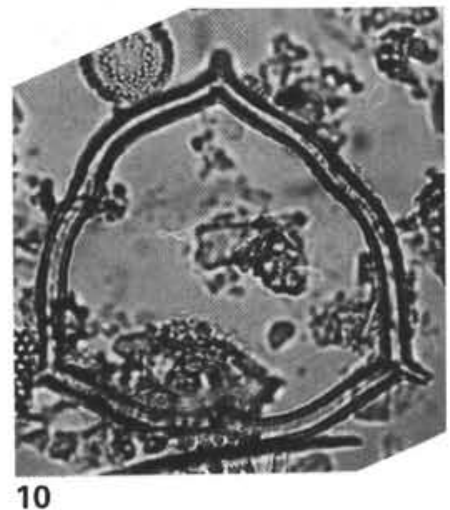

10

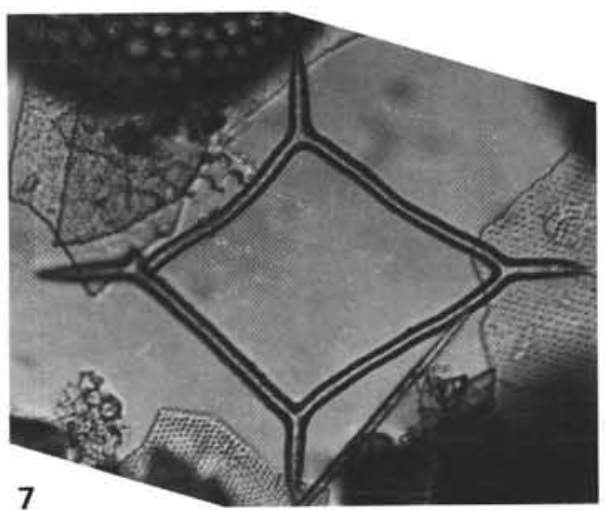

7

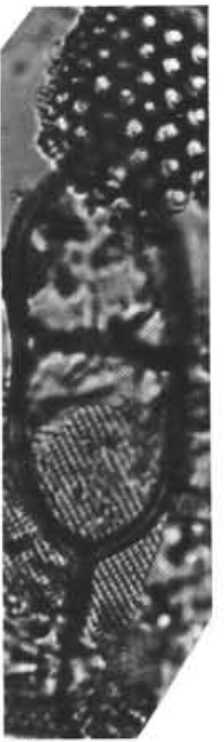

11

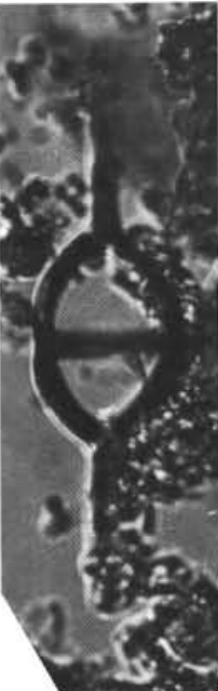

12

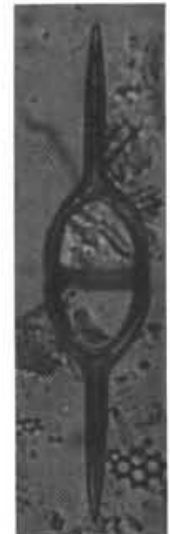

13

Plate 14. (All specimens $\times 600$.) 1-2. Mesocena oamaruensis Schulz, 1928, (1) Sample 511-3-2, 65-66 cm, (2) Sample 512-7-3, 60-62 cm 3-8. Mesocena occidentalis Hanna, 1931, (3) Sample 511-1-4, 15-16 cm, (4) Sample 512-6,CC, (5) Sample 512-12,CC, (6) Sample 512-18,CC, (7) Sample 512-12,CC, (8) Sample 512-6-1, 78-80 cm. 9-10. Mesocena, aberrant forms, (9) Sample 512-16-2, 15-17 cm, (10) Sample 512-11-1, 74-76 $\mathrm{cm}$. 11-13. Naviculopsis biapiculata (Lemmermann) Frenguelli, 1940, (11) Sample 511-17-2, 80-82 cm, (12) Sample 511-16-3, 19-21 cm, (13) Sample 511-3-2, 65-66 cm. 


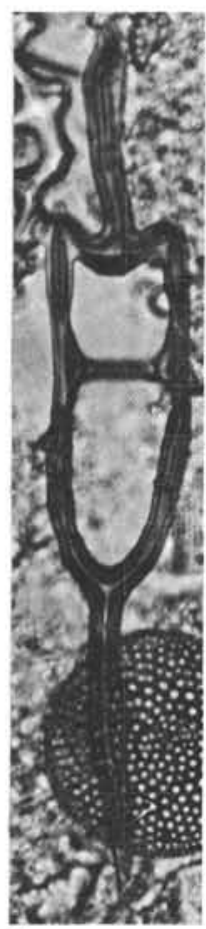

1

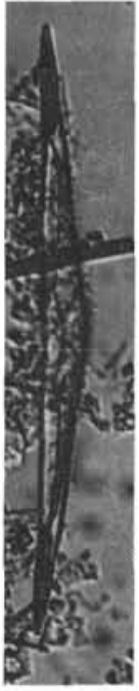

9

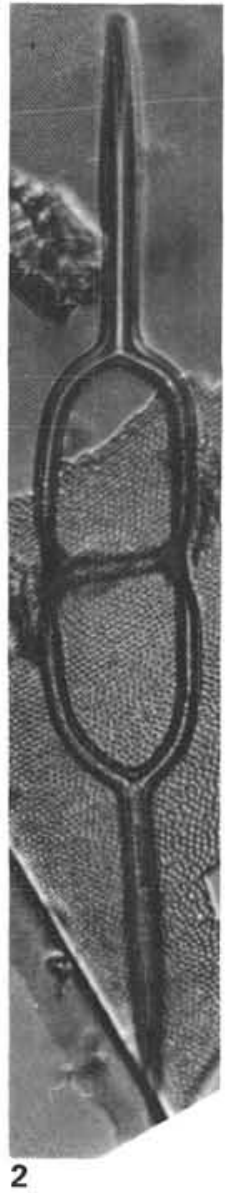

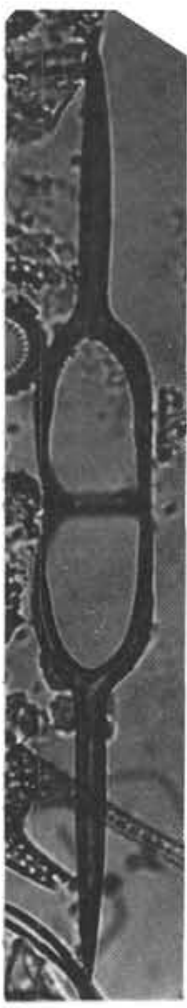

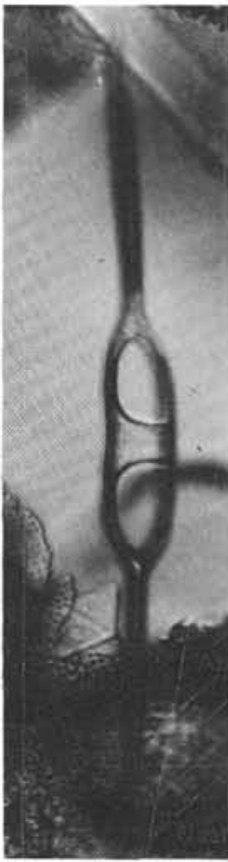

4

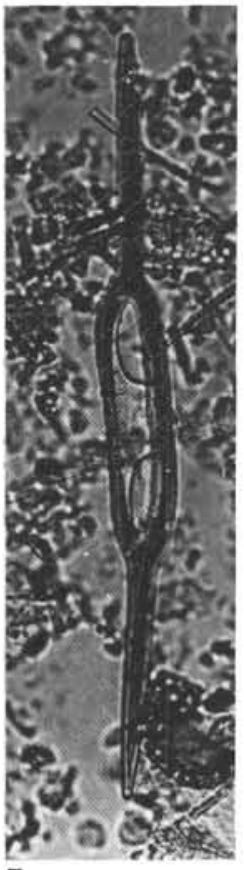

5

3
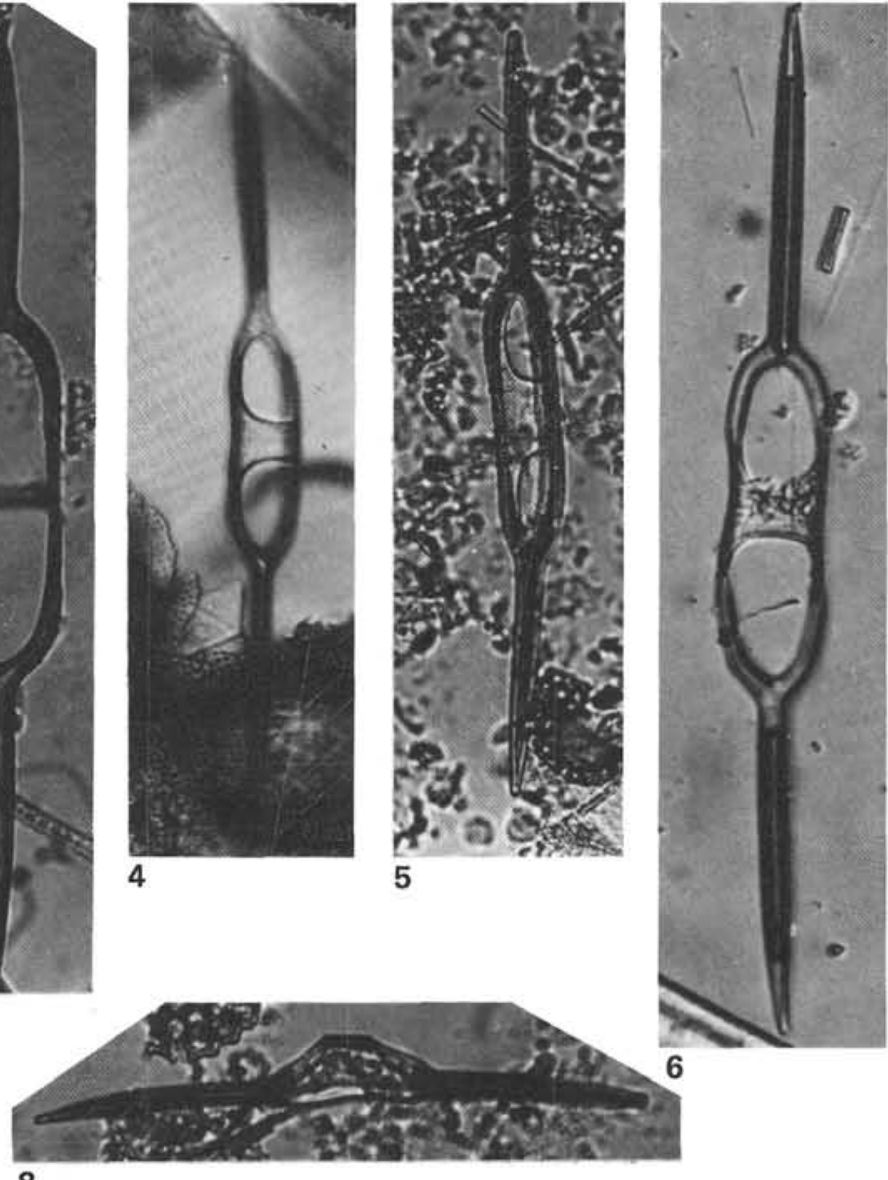

6

8
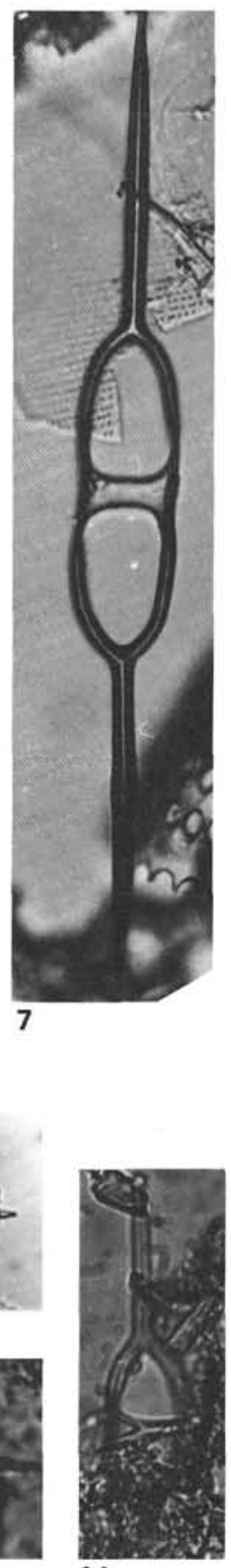

14

Plate 15. (All specimens $\times 600$.) 1-3. Naviculopsis biapiculata (Lemmermann) Frenguelli, 1940, (1) ìample 512A-2-1, 93-94 cm, aberrant form, (2) Sample 512-8,CC, (3) Sample 512-15-1, 67-69 cm. 4-8. Naviculopsis constricta (Schulz) Frenguelli, 1940, (4) Sample 512-12, CC, (5) Sample 512-11-3, 48-50 cm, (6) Sample 512-8,CC, (7) Sample 512-14,CC, (8) Sample 512-6-1, 78-80 cm. 9-13. Naviculopsis nordica hyalina Bukry, 1976b, (9) Sample 512-12-3, 54-56 cm, side view, (10) Sample 512-11-3, 48-50 cm, (11) Sample 512-11-2, 56-68 cm, (12) Sample 512-14-2, 44-46 cm, (13) Sample 512-18-1, 37-39 cm. 14. Naviculopsis punctilia Perch-Nielsen, 1976, Sample 511-5-1, 5-7 cm. 


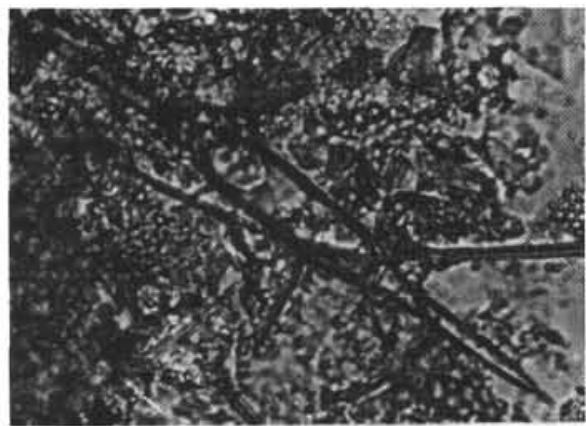

1

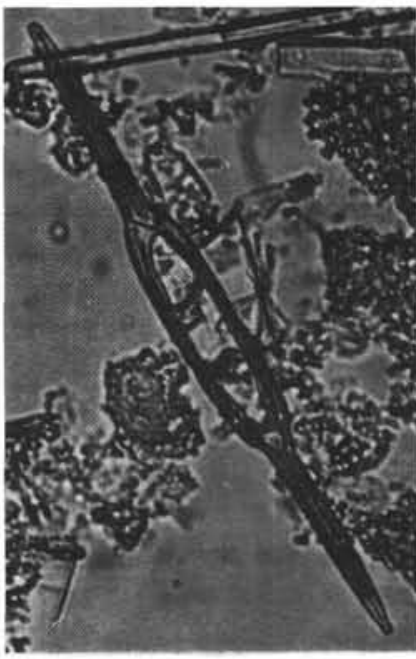

6
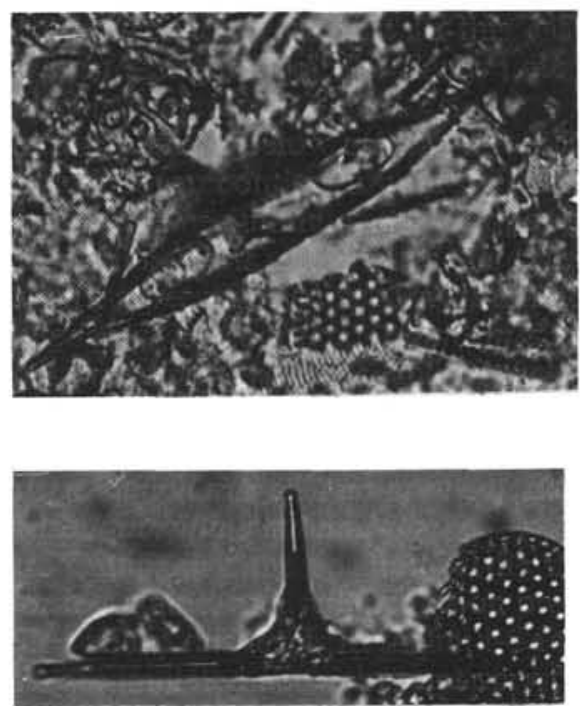

8
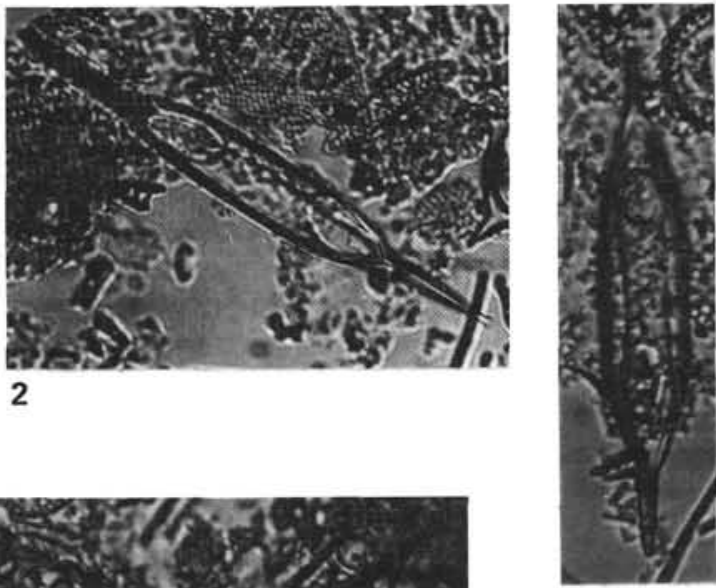

3

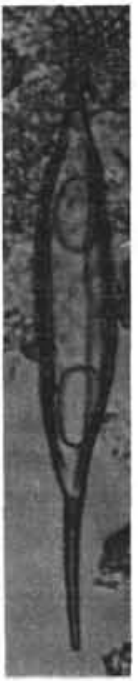

4

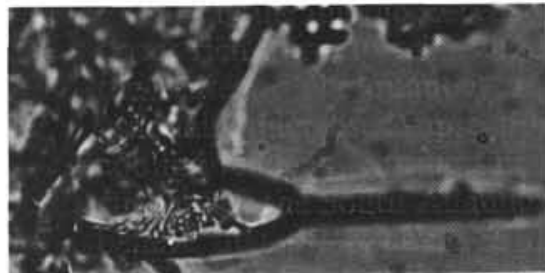

9a

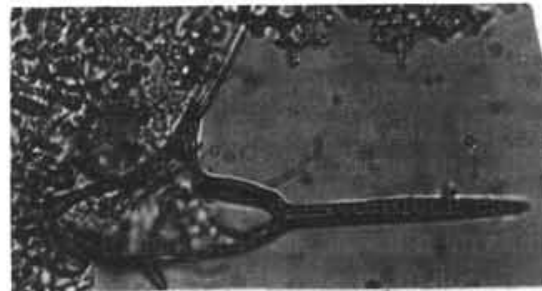

9b

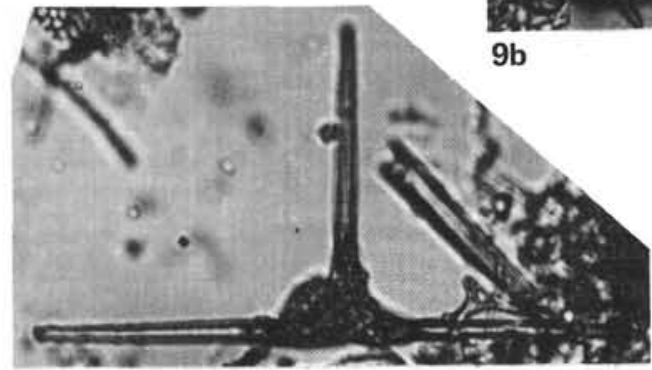

11

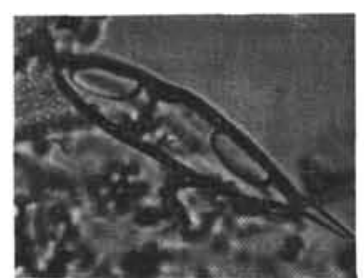

12

Plate 16. (All specimens $\times 600$.) 1-7, 10, 12. Naviculopsis foliacea Deflandre, 1950, (1) Sample 512-6-1, 78-80 cm, (2) Sample 512-12-3, 54-56 cm, (3) Sample 512A-2-1, 93-94 cm, (4) Sample 512-17-2, 22-24 cm, (5) Sample 512-13-2, 43-45 cm, (6) Sample 512-6-1, 78-80 cm, (7) Sample 512-16-2, 15-17 cm, (10) Sample 512-9-3, 60-62 cm, (12) Sample 512-18-1, 37-39 cm. 8, 11. Naviculopsis trispinosa (Schulz) Glezer, 1966, (8) Sample 511-1-4, 15-16 cm, side view, (11) Sample 511-2-4, 20-21 cm, side view. 9. Naviculopsis, Sample 511-6,CC, aberrant form, (a) oblique apical view, focus on apical apparatus, (b) oblique apical view, focus on spines. 


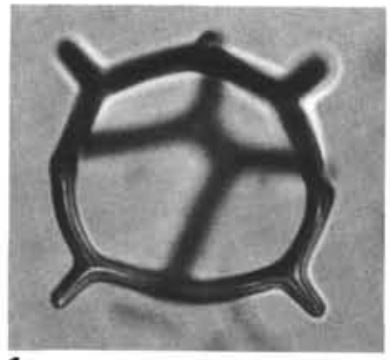

1a

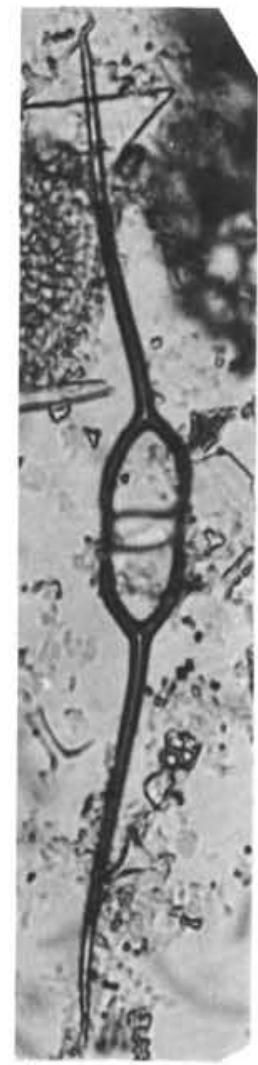

4

3

5

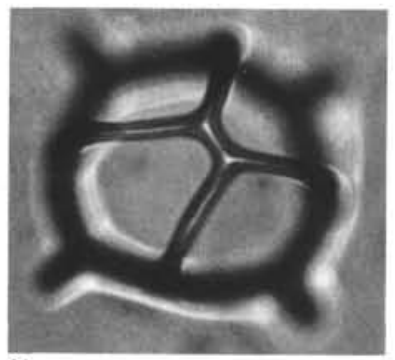

1b
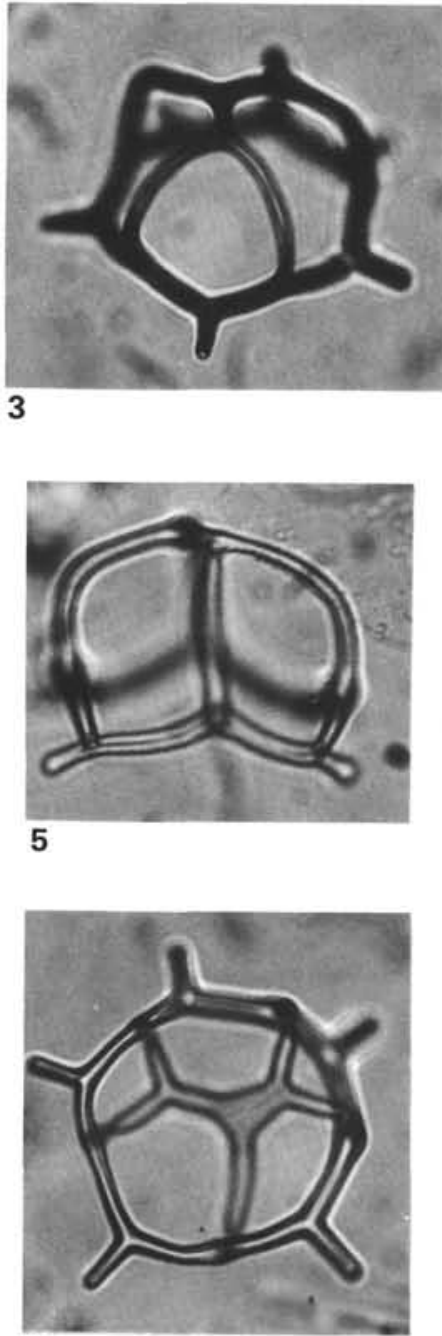

$8 a$

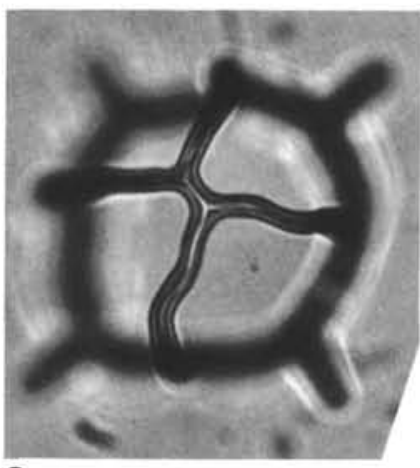

$2 a$

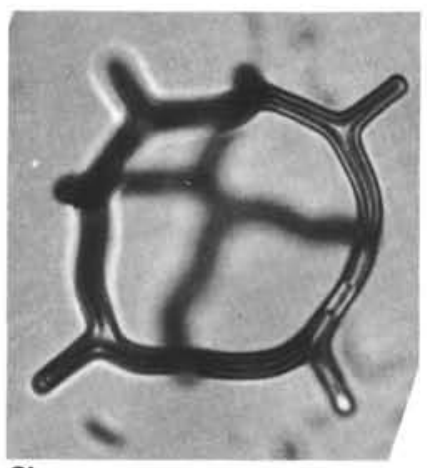

2b

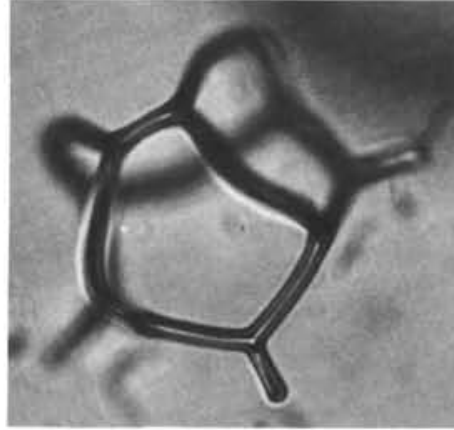

6

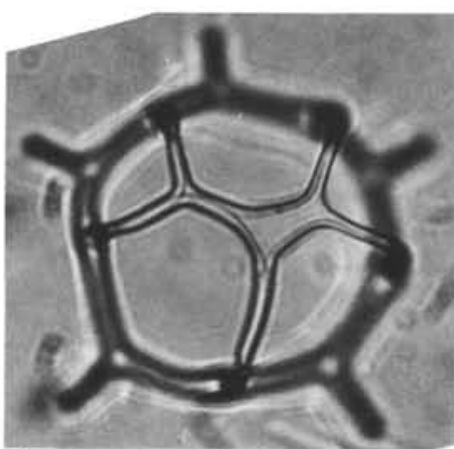

$8 b$
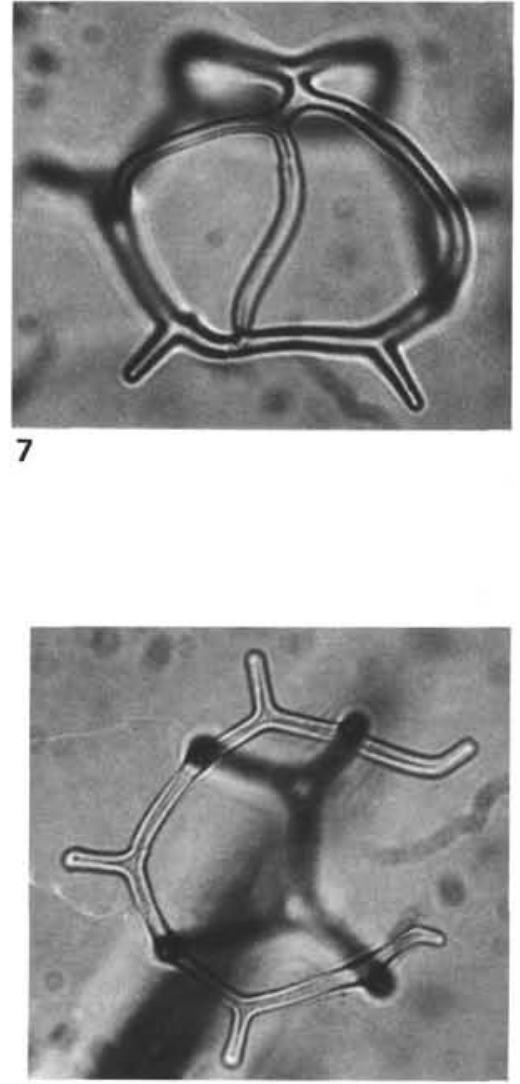

9

Plate 17. (All specimens with the exception of Figure 8 b magnified $\times 600$.) 1-3, 5-9. Dictyocha alta n.sp., Sample 513A-26,CC. (1) a, holotype, basal focus; b, apical focus, (2) a, paratype, apical view showing wavy apical rods; b, basal view, (3) paratype, oblique apical view of a six-sided form, (5) Paratype, side view showing basal ring (bottom of photo) and nearly vertical lateral rods joined to form apical apparatus, (6) oblique apical view, (7) paratype, oblique apical view of a six-sided form, (8) a, basal focus of a five-sided form; b, $\times 690$, apical view showing tubular structure of the apical apparatus, (9) basal focus of an aberrant five-sided form. 4. Naviculopsis constricta (Schulz) Frenguelli, 1940, Sample $513 \mathrm{~A}-32-1,5-7 \mathrm{~cm}$, specimen with unusually long spines. 


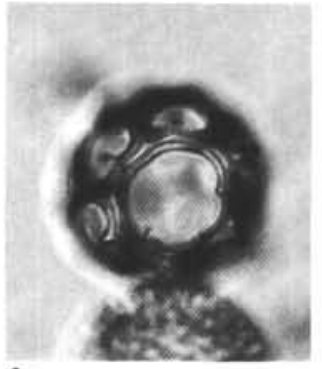

1a

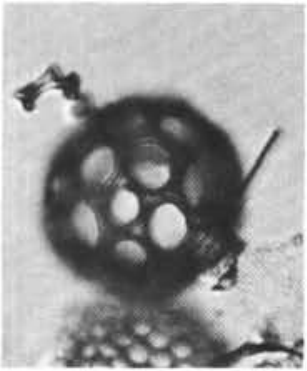

$1 b$
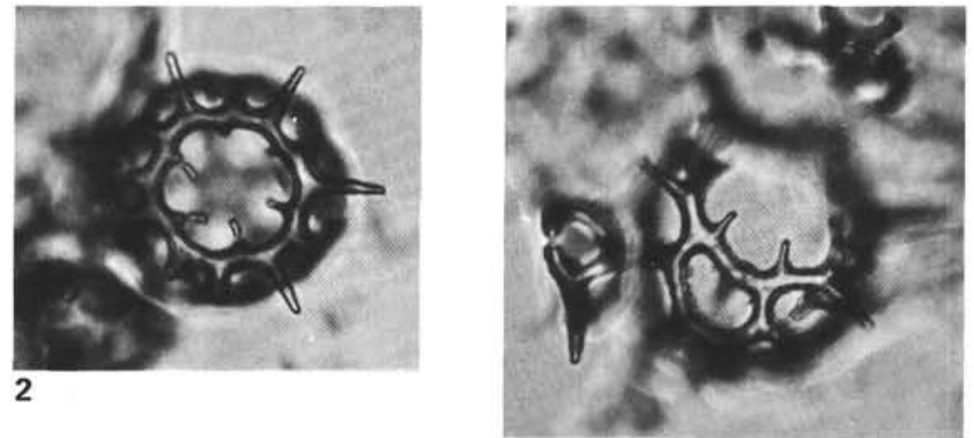

3

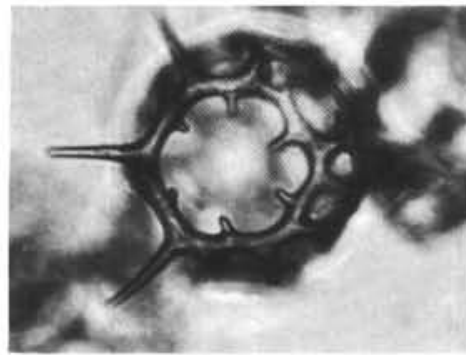

$5 b$

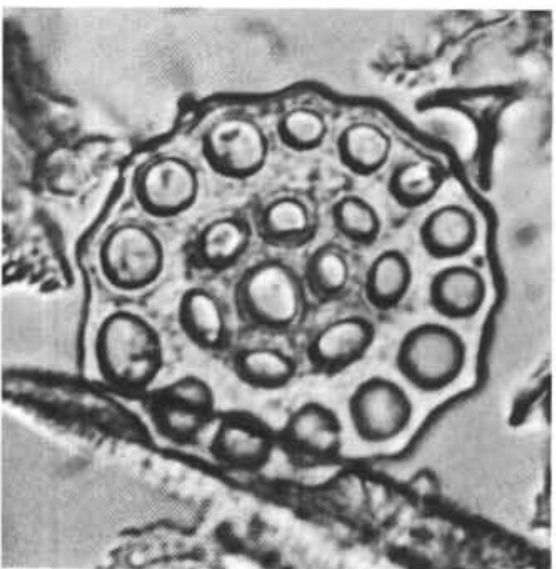

6

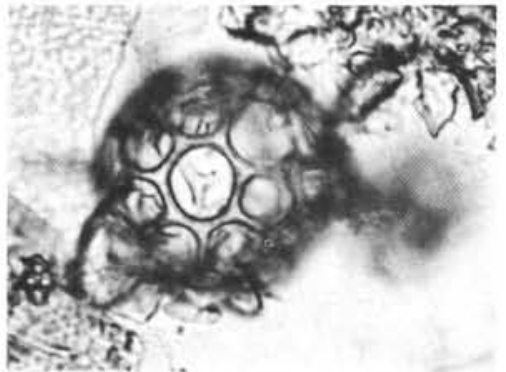

$5 a$
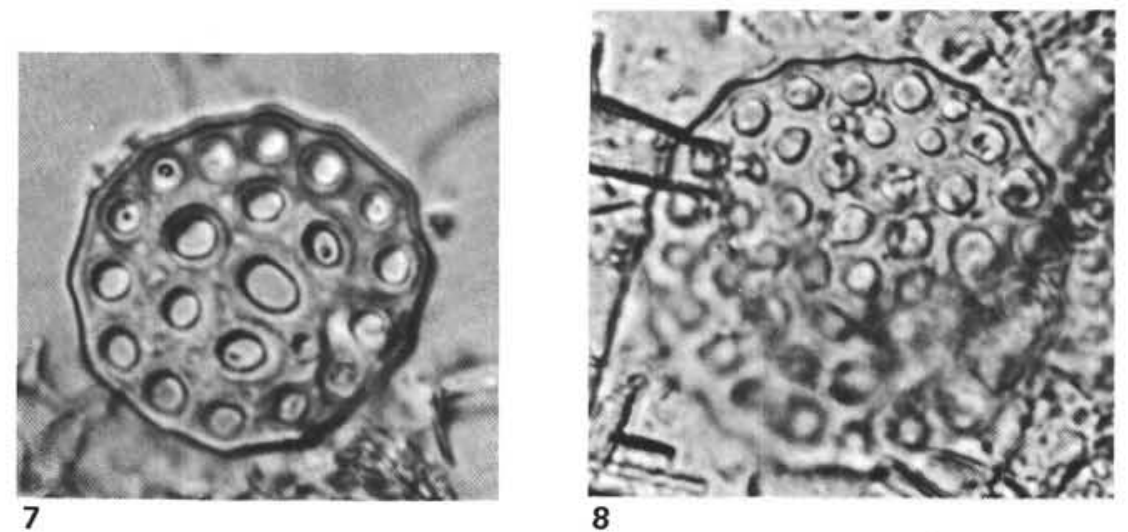

Plate 18. (All specimens $\times 600$.) 1-5. Cannopilus sphaericus Gemeinhardt, Sample $513 \mathrm{~A}-26, \mathrm{CC},(1) \mathrm{a}$, basal focus; $b$, view through basal opening with focus on inside of apical apparatus, (2) basal view showing radial basal spines and accessory spines, (3) oblique basal view showing basal and accessory spines, (4) side view, (5) a, view through basal opening with focus on inside of apical apparatus; b, basal view. 6. Macrora stella (Azpeitia) Hanna, 1932. Sample 513A-16-3, 23-25 cm. 7, 8. Macrora barbadensis (Deflandre) Bukry, 1977, (7) Sample 513A-14-6, 46-48 cm, (8) Sample 513A-16-3, 23-25 cm. 


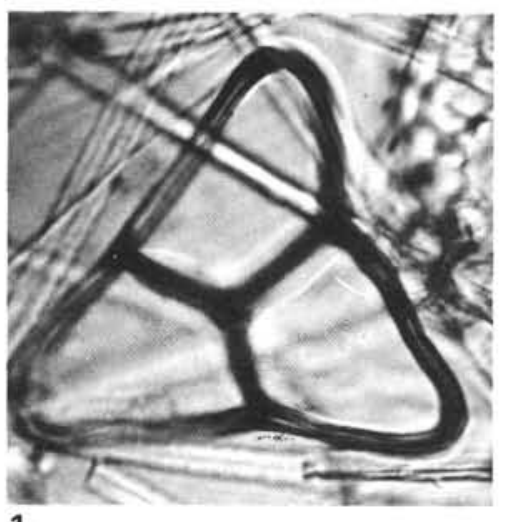

1

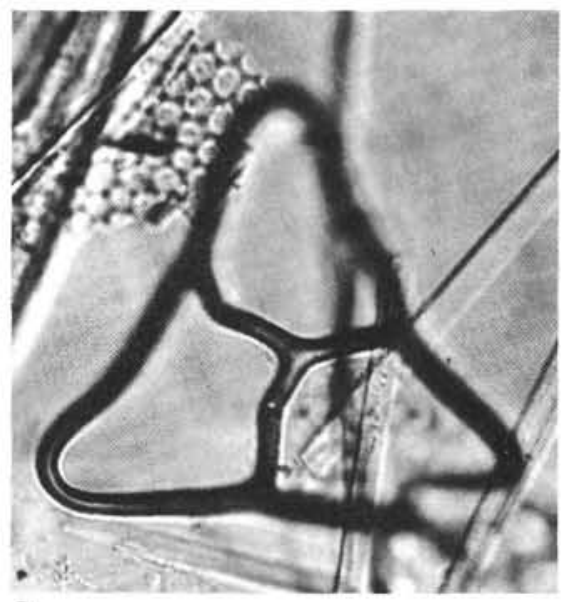

2

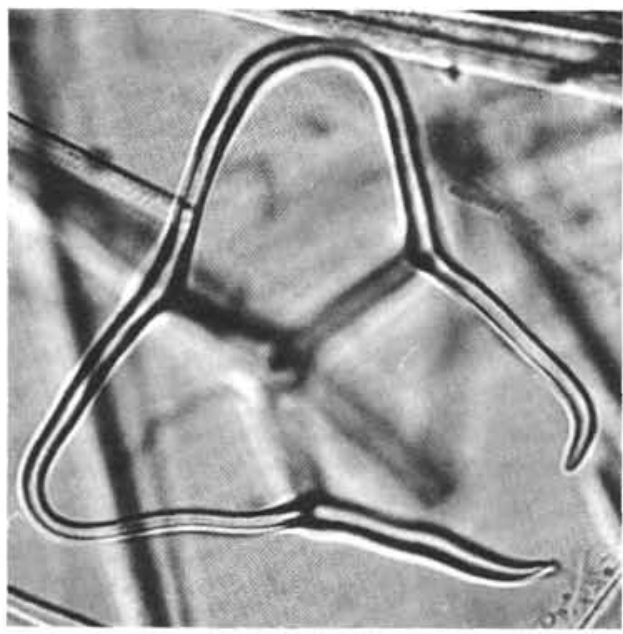

4

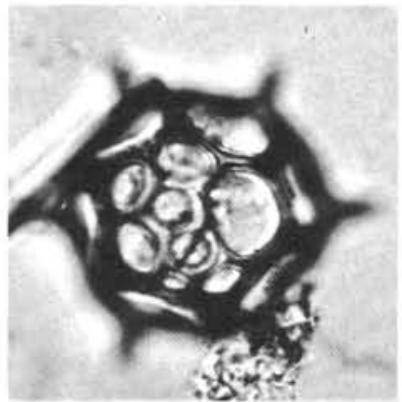

7

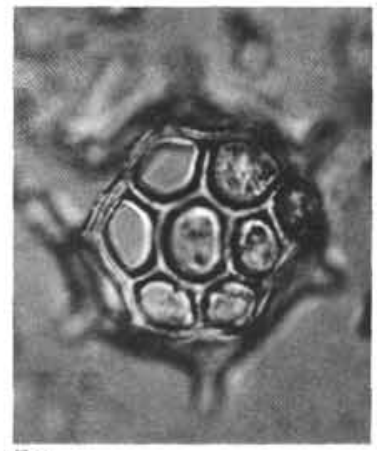

$5 a$

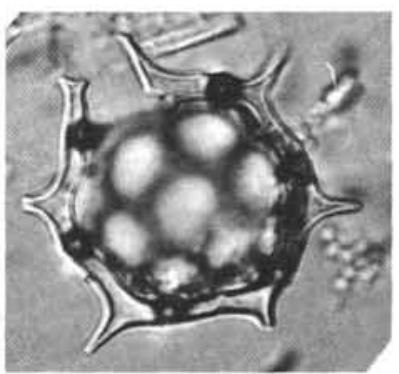

$5 b$

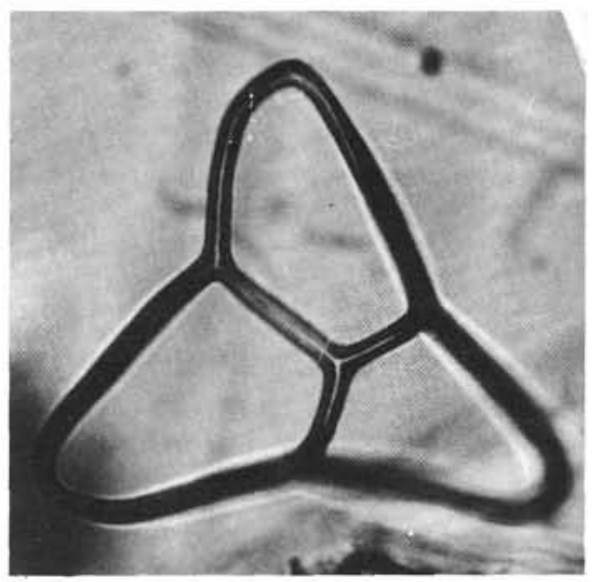

3

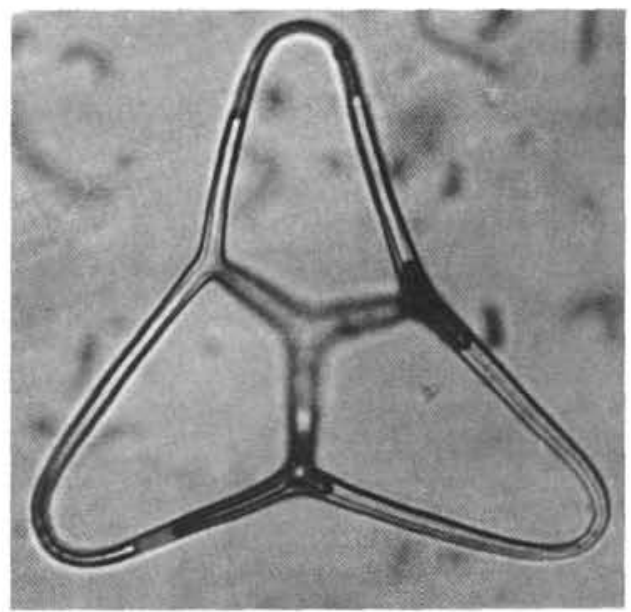

6

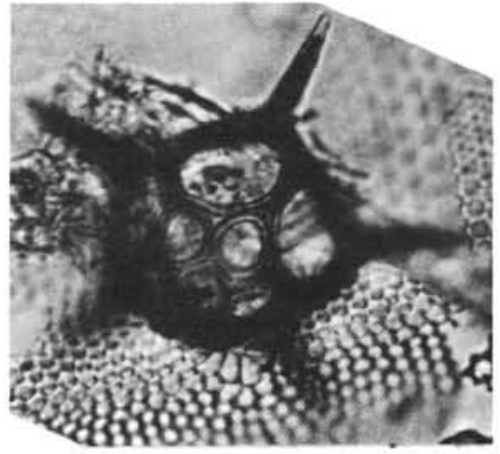

8

Plate 19. (All specimens $\times 600$.) 1-4, 6. Corbisema archangelskiana (Schulz) Frenguelli, 1940, (1-4) Sample 513A-21-1, 70-72 cm (2, 4, aberrant forms), (6) Sample 513A-16-3, 23-25 cm. 5, 7-9. Distephanus boliviensis hemisphaericus (Ehrenberg) Bukry, (5) Sample 513A-18-3, 70-72 cm (a, focus on apical apparatus; b, focus on aberrant basal ring), (7) Sample 513A-18-3, focus on apical apparatus, (8) Sample 513A-14-6, 46-48 $\mathrm{cm}$, pentagonal form. 

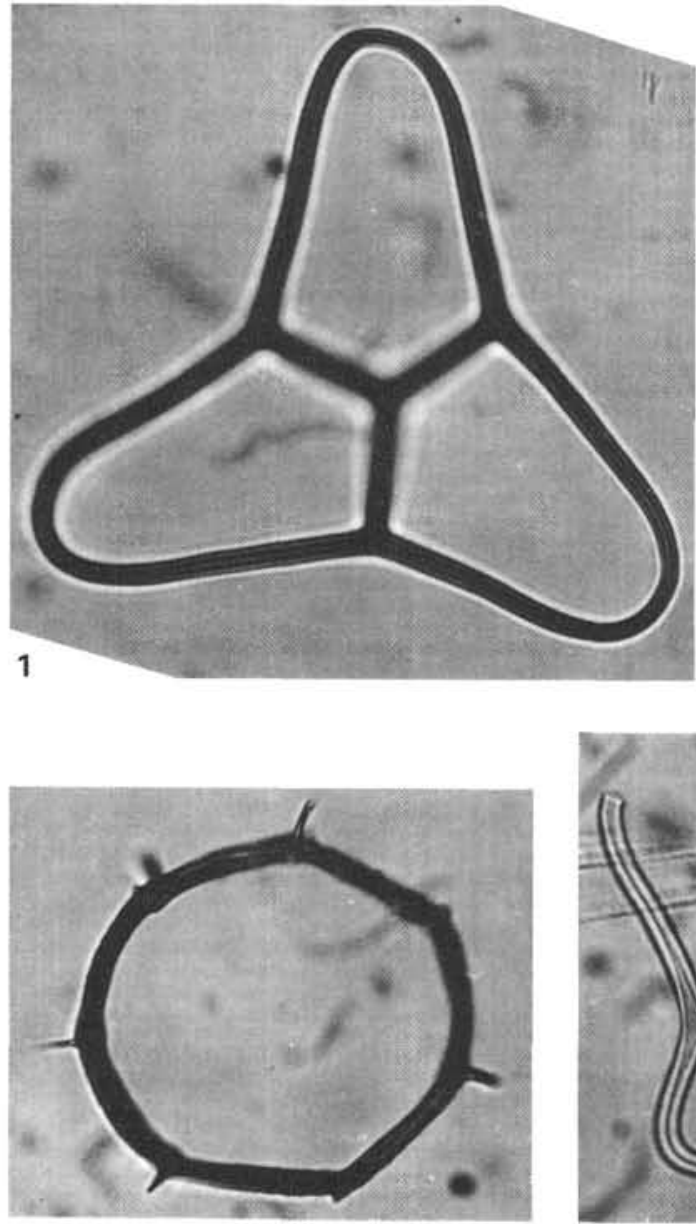

3

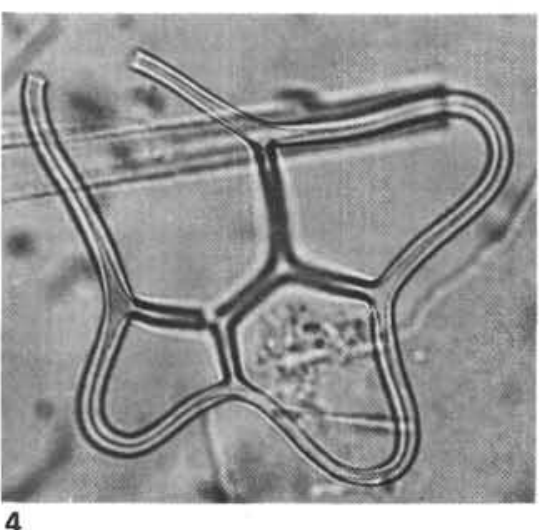

4
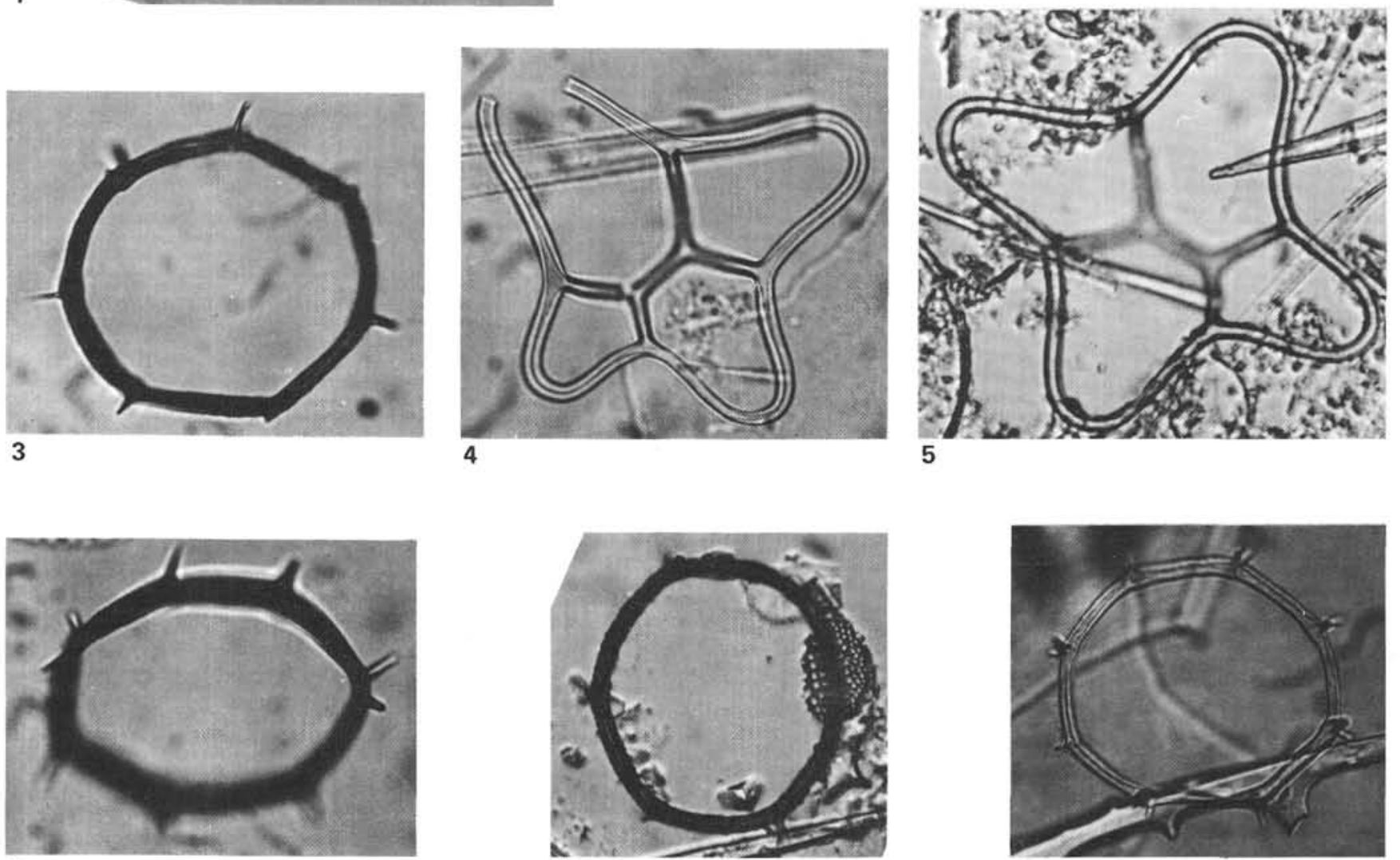

6

Plate 20. (All specimens $\times 600$.) 1. Corbisema archangelskiana (Schulz) Frenguelli, 1940. Sample 513A-15-3, 119-121 cm. 2, 4-5. Dictyoche quadria (Mandra) Martini and Müller, 1976, (2) Sample 513A-17-3, 22-24 cm, (4-5) Sample 513A-21-1, 70-72 cm. 3, 6-8. Mesocena bispicate n.sp. (3) Sample 513A-26,CC, holotype, (6-8) Sample 513A-26,CC, paratypes.
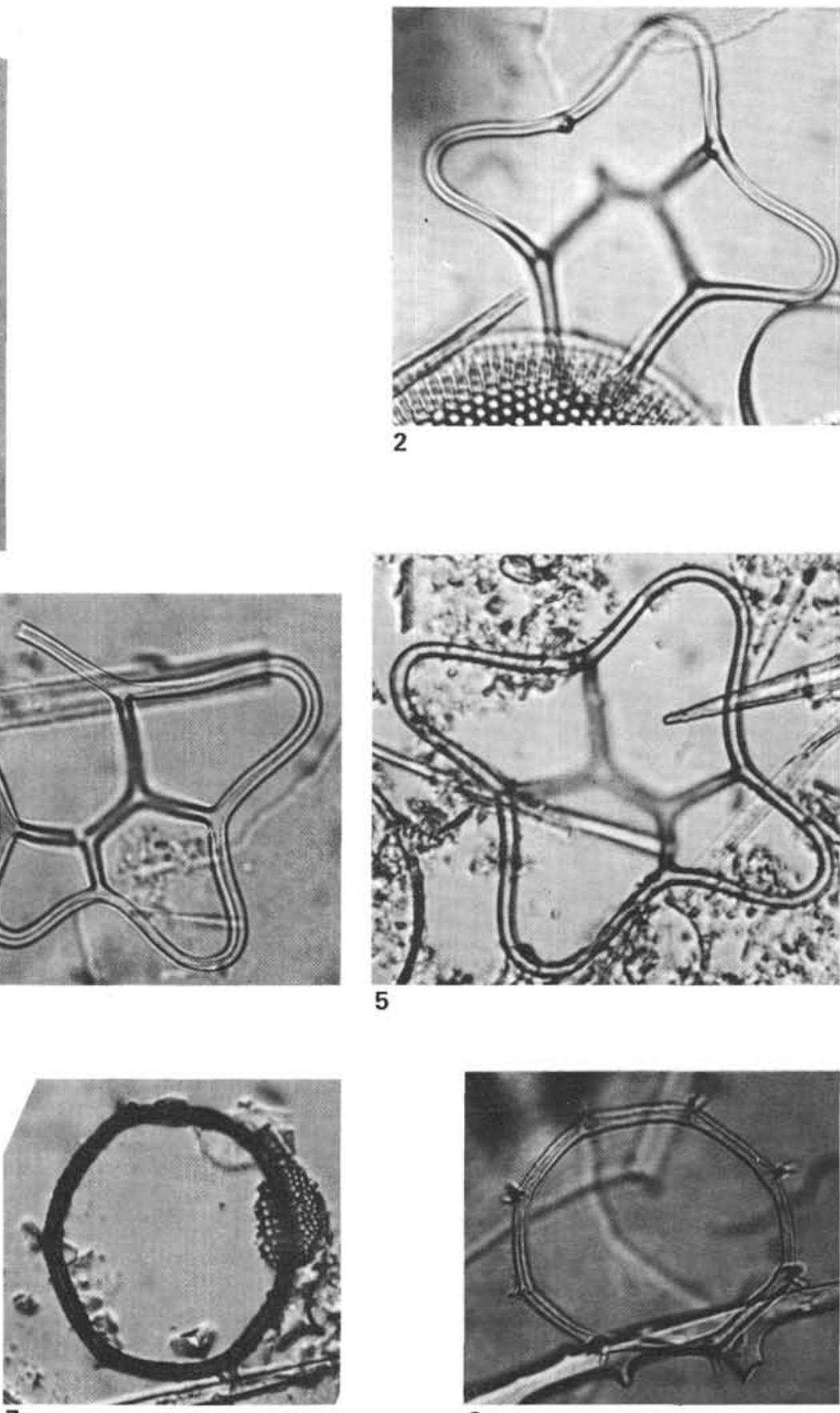

8 